\title{
Modelling economic and biophysical drivers of agricultural land-use change. Calibration and evaluation of the Nexus Land-Use model over 1961-2006
}

\section{F. Souty ${ }^{1,2}$, B. Dorin ${ }^{1,3}$, T. Brunelle ${ }^{1}$, P. Dumas ${ }^{1,3}$, and P. Ciais ${ }^{2}$}

${ }^{1}$ Centre International de Recherche sur l'Environnement et le Développement, Nogent-sur-Marne, France

${ }^{2}$ Laboratoire des Sciences du Climat et de l'Environnement, UMR8212, Gif-sur-Yvette, France ${ }^{3}$ Centre de Coopération Internationale en Recherche Agronomique pour le Développement, Montpellier, France

Received: 20 November 2013 - Accepted: 22 November 2013

- Published: 19 December 2013

Correspondence to: T. Brunelle (brunelle @ centre-cired.fr)

Published by Copernicus Publications on behalf of the European Geosciences Union.
Calibration and evaluation of the Nexus Land-Use

model

F. Souty et al

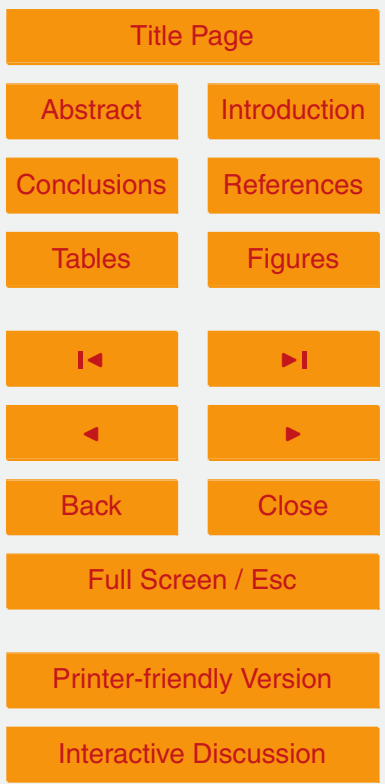




\section{Abstract}

The central role of land-use change in the Earth System and its implications for food security, biodiversity and climate has spurred the development of global models that combine economical and agro-ecological drivers and constraints. With such a develop5 ment of integrated approaches, evaluating the performance of global models of landuse against observed historical changes recorded by agricultural data becomes increasingly challenging. The Nexus Land-Use model is an example of land-use model integrating both biophysical and economical processes and constraints. This paper is an attempt to evaluate its ability to simulate historical agricultural land-use changes over 12 large but economically coherent regions of the world since 1961. The evaluation focuses on the intensification vs. extensification response of crop and livestock production in response to changes of socio-economic drivers over time, such as fertiliser price, population and diet. We examine how well the Nexus model can reproduce annual observation-based estimates of cropland vs. pasture areas from 1961 to 2006. Food trade, consumption of fertilisers and food price are also evaluated against historical data. Over the 12 regions considered, the total relative error on simulated cropland area is $2 \% \mathrm{yr}^{-1}$ over 1980-2006. During the period 1961-2006, the error is larger $\left(4 \% \mathrm{yr}^{-1}\right)$ due to an overestimation of the cropland area in China and Former Soviet Union over 1961-1980. Food prices tend to be underestimated while the performances of the trade module vary widely among regions (net imports are underestimated in Western countries at the expense of Brazil and Asia). Finally, a sensitivity analysis over a sample of input datasets provides some insights on the robustness of this evaluation.
GMDD

$6,6975-7046,2013$

Calibration and evaluation of the

Nexus Land-Use

model

F. Souty et al.

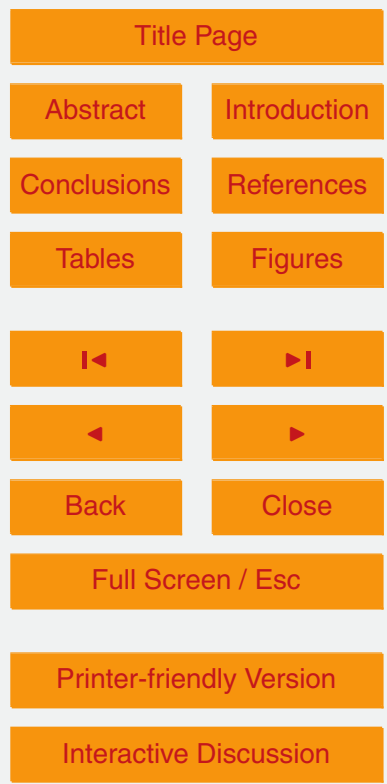




\section{Introduction}

Agricultural land-use changes result from a wide diversity of mechanisms. They relate to bioclimatic conditions (climate, soil, slope, etc.), demand for food and other agricultural products like agroenergy, technology to increase yield (intensification), prices of 5 inputs (fertilisers, pesticides, water, etc.), labour and public regulations (environment, trade, etc.). Most of these drivers are region-specific and interconnected via trade and other feedback mechanisms.

The Nexus Land-Use model (Souty et al., 2012) focuses on the interplay between biophysical potentials and economic drivers. It simulates agricultural land-use changes over the world through the intensification/extensification responses of crop and livestock productions, in response to exogenous scenarios of food and agroenergy demands, evolution of forest areas and changes in fertiliser and pesticide prices.

This paper aims at evaluating land-use mechanisms represented in the Nexus LandUse model by comparing its results against data on historical land-use changes between 1961 and 2006. Such model evaluation is common in the physical sciences, but is almost nonexistent in economics (Beckman et al., 2011). Indeed, given the complexity of socio-economic systems and their evolution over time, economics generally uses stylised and simplified assumptions (e.g., individual rationality, representative agent) not to faithfully reproduce past evolutions but rather to provide a framework for studying, for instance, the effects of a policy, or the gap between the reality and an "optimal" situation. Actually, a model must be evaluated in light of its intended use. Most economic models, especially long term models, are not designed for predictions, but rather for comparing a range of policy options the results of which are nontrivial due to numerous interactions. Such models are especially useful when they help to reveal unexpected consequences of a policy option. Amongst the few global land-use models representing biophysical mechanisms and economic behaviours, KLUM@GTAP and MAgPIE are two examples that have compared their results against historical data (Ronneberger et al., 2008; Lotze-Campen et al., 2008). These evaluations provide valuable insights
GMDD

Calibration and evaluation of the

Nexus Land-Use model

F. Souty et al.

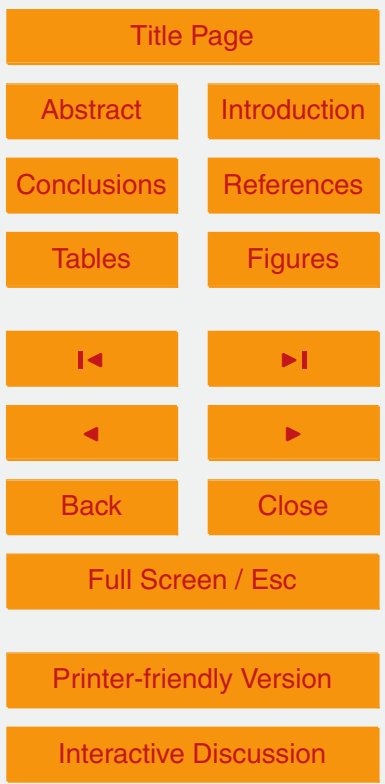


on the models' capacities to reproduce land-use changes. Several outputs have been compared against independent agricultural observation data: changes in the area of cropland on each grid point, changes in yields and shares of different crop types in regional cropland areas (MAgPIE) and prevailing crop in each country (KLUM@GTAP).

5 The merit of these works is above all to highlight limits or weaknesses of the models. For instance, the evaluation of the MAgPIE model shows more errors for Africa and Middle East than other regions due to regional specificities and biases from the underlying vegetation model.

In this paper, the Nexus Land-Use model is calibrated and evaluated through retro10 ponents of the model (in particular the yield response functions and the international
trade module). We evaluate the sensitivity of these components to input parameters and calibrated them. In a second step, several model outputs are compared with historical census data: cropland area, food price, fertiliser consumption, food trade (Fig. 1). 15 The 12 regions of the model are: USA, Canada, Europe, OECD Pacific (including Australia, Japan, New Zealand and South Korea), Former Soviet Union (FSU), China, India, Brazil, Middle East, Africa, the Rest of Asia and the Rest of Latin America (Rest of LAM).

The next section briefly reviews the main features of the model and changes made 20 from version 1.0 (Souty et al., 2012). Section 3 describes the data used to force retrospective simulations (food demand, fertiliser price, irrigation, feeding practices, etc.). In Sect. 4 we calibrate and evaluate specific model components. Finally, Sect. 5 investigates the capacity of the model to reproduce $45 \mathrm{yr}$ of changing agricultural land use that occurred during the period 1961-2006. Section 6 tests the sensitivity of this
GMDD

$6,6975-7046,2013$

Calibration and evaluation of the

Nexus Land-Use

model

F. Souty et al.

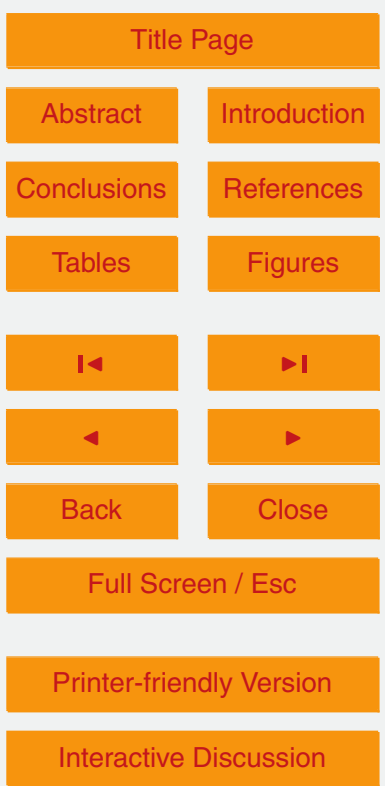




\section{The Nexus Land-Use model}

\subsection{Short description}

As described in Souty et al. (2012), the Nexus Land-Use model is a partial equilibrium model in which the agricultural sector is discretised in 12 regions of the world,

5 inter-connected with each other by international trade. The model inputs are regional temporal profiles of: (i) consumption of food calories (population multiplied by average diet per capita), (ii) production of agrofuel, (iii) forest area, (iv) price of fertilisers and pesticides, ( $v$ ) other cropland area and other production (see below). Outputs are: (i) area of cropland and its distribution over land classes, (ii) areas of intensive vs. extensive pastures, (iii) consumption of fertilisers and pesticides, (iv) food crop calorie price.

In contrast to similar land-use models such as MAgPIE (Lotze-Campen et al., 2008) or GLOBIOM (Havlík et al., 2011), the Nexus Land-Use does not run on a spatial grid but uses the concept of land classes of different potential yields within each region. Gridded input data on land-use (forests, pastures and croplands) and potential crop yields are transformed into land classes of increasing potential yields. Potential crop yields are defined as maximum attainable yields with maximal use of fertiliser and pesticide, in rainfed and irrigated conditions. Since potential crop yields are not available for all crops, crops are divided into two categories in each region. The first category, called dynamic crops (because their yield and area responds dynamically to changes in model input), corresponds to crops for which potential yield estimates are available. The second, called other crops, includes remaining crops and fallow lands, the areas and corresponding productions of which are exogenously set. Potential yields of dynamic crops are provided by the spatially explicit vegetation model LPJmL for 2511 crop functional types, with and without irrigation, on all earth's lands discretised on a $0.5^{\circ} \times 0.5^{\circ}$ grid (Bondeau et al., 2007). These potential yields are converted into a food calorie equivalent and aggregated into an average crop potential yield on each grid cell, including cropland, and taking into account the fractional coverage of each

Calibration and evaluation of the Nexus Land-Use model

F. Souty et al.

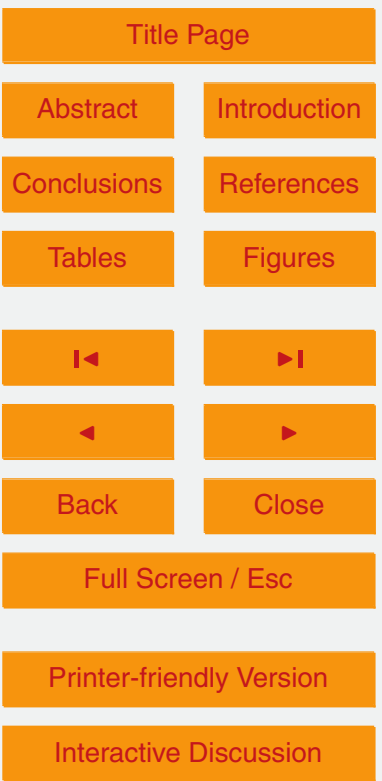


crop around year 2000 for irrigated and rainfed areas separately. Areas of dynamic crops are binned into land classes of increasing potential yield values. Other land uses (pastures, forests and other croplands) are associated with a rainfed hypothetical yield should these lands be converted into dynamic croplands. To calculate this hypothet5 ical yield, LPJmJ potential yields under rainfed conditions were aggregated into one potential yield on each grid cell of land using the actual crop mix in each country. This amounts to assuming that when dynamic cropland expands, new crops are cultivated without irrigation and the proportion of each new crop planted corresponds to the current fraction of this crop at the national scale.

10 In each region, it is assumed that agricultural expansion (cropland and pasture) can only be made at the expense of forest. Therefore, the expansion of urban areas, degradation of agricultural lands, and other land-use changes are neglected. The production of seed and waste are a proportional share of each type of agricultural production. Demand for non-food agricultural products, including agrofuels, is exogenously set. Trade 15 is calculated using price ratios between domestic and world prices. Agricultural product exports cannot grow above limits representing food sovereignty considerations. Regional demands for production of animal food are converted into feed needs, using the livestock production model of Bouwman et al. (2005). Regional demands of food and feed are then converted into cropland and pasture area.

Two mechanisms drive the actual yield of dynamic crops in Nexus Land-Use. Firstly, in each land class of each region, yield is modelled as an increasing function of fertiliser and pesticide use. This crop production function is similar to the yield response to inputs of nitrogen fertilisers: decreasing returns and an asymptote equal to the potential yield of the land class. It is used to calculate an "optimal" yield that minimises the production costs computed with fertiliser and pesticide prices and the endogenous calorie price. Secondly, following Ricardo (1817), Nexus Land-Use assumes a production frontier between fertile and less fertile lands: intensive production systems of crop and pastures (used for crop and livestock production) are located on best, high-yield lands, and extensive production systems (non-fertilised pastures used for grazing only)
GMDD

6, 6975-7046, 2013

Calibration and evaluation of the Nexus Land-Use model

F. Souty et al.

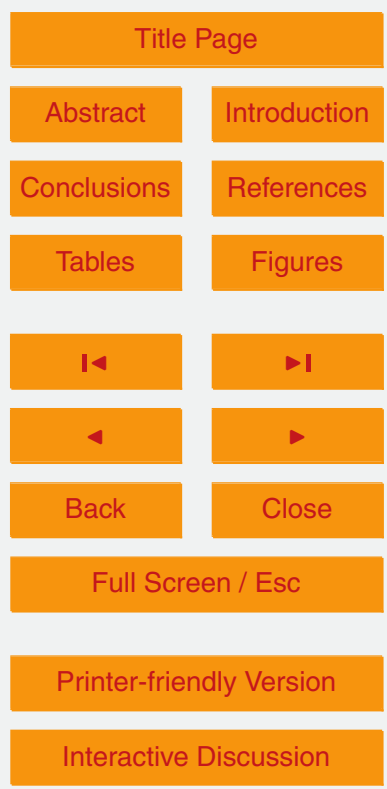


are located on low-yield lands. When pressure on land rises, the intensive system grows at the expense of the extensive system.

Three types of pasture are considered, intensive (with inputs), extensive (without inputs) and so-called residual pastures. Residual pastures are located on high-yield 5 land classes but they are part of the extensive production system (no input and grazing only, Souty et al., 2012, p. 1309 and 1312). Considered to be an inefficient use of land from the point of view of economic return, the area of residual pastures in each land class is reduced as soon as the pressure on agricultural land is higher than its reference level in 2001.

\subsection{Changes from previous version}

Four changes were made in the parametrisations of Nexus Land-Use version 1.0 described by Souty et al. (2012):

- Data of intensive pasture areas at the base year 2001 from Bouwman et al. (2005) were updated with a new dataset (L. Bouwman, personal communication, 2011). There are changes compared to the previous dataset for the United States $(-47 \%)$, the Middle East $(+32 \%)$, Canada $(+107 \%)$ and Brazil $(+213 \%)$ (see Appendix A1).

- The global supply/demand balance (Souty et al., 2012, p. 1301) now integrates LPJmL's fodder crops. Globally, in 2001, these crops represent only $3.4 \%$ of total dynamic crop production in calories, but reach $12.3 \%$ in the FSU (see Appendix A2).

- Other food crop productions are no longer assumed to be constant, as was the case in Souty et al. (2012), but are set proportionally to the total food crop demand in each region.

- Costs of industrial inputs (fertilisers, pesticides, mineral enrichments) for the production of dynamic crops in 2001, IC $\mathrm{C}_{\chi}$, are no longer based on GTAP 6 values 6981
GMDD

$6,6975-7046,2013$

Calibration and evaluation of the

Nexus Land-Use

model

F. Souty et al

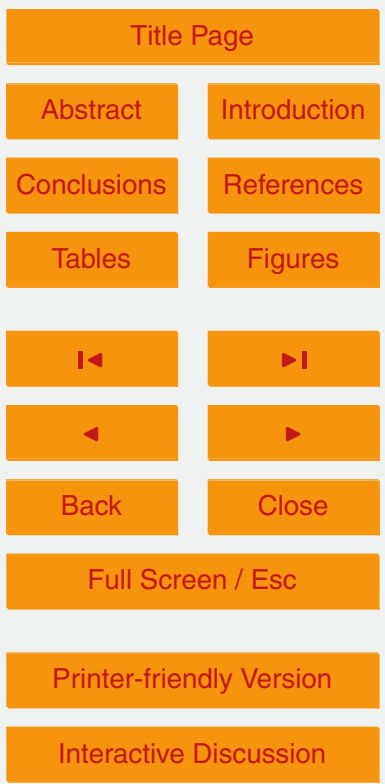

Interactive Discussion 
(GTAP, 2006) but on nitrogen, phosphate and potash (NPK) fertiliser consumption values calculated with FAOSTAT data (FAO, 2012, see Sect. 3.2 for details). These new monetary values are used to calibrate the initial slope $\alpha_{\mathrm{IC}}$ of the crop production function (Souty et al., 2012, Eqs. 34 and 35). Mineral NPK fertilisers represent the most widespread industrial inputs used by agriculture. They do not cover all chemical inputs reported in GTAP but their costs can now be associated with quantities (tonnes of fertilisers) unlike with GTAP. Moreover, absolute values of $\mathrm{IC}_{\chi}$ are not essential since the model deals with quantities and relative prices, the latter being used only in the trade module of Nexus Land-Use.

- New actual and potential yields were computed to take into account multicropping. Using a dataset of harvested areas of each CFT on each grid cell (A. Bondeau, personal communication, 2013), we increased actual and potential yields proportionally to the number of harvests per year. As a result, the share of dynamic crops in global food crop calorie production amounts to $87 \%$ while it was $75 \%$ in the previous version (the cultivated area of dynamic crops is still $51 \%$ of total cropland area, see Appendix A3).

\section{Historical data for model evaluation (1961-2006)}

The overall goal of this paper is to examine how well the Nexus Land-Use model can reproduce the Ramankutty and Foley (1999) annual observation-based estimates of cropland vs. pasture areas from 1961 to 2006 in each region. In a preliminary step, we focus on two major mechanisms: the function determining the crop yield in each land class and the international trade module. Their outputs are compared to historical data and their parameters are calibrated. In addition, we evaluate the grassland yield and the sensitivity of the maximal conversion speed of residual pastures (Sect. 4). Then, the
GMDD

Calibration and evaluation of the

Nexus Land-Use model

F. Souty et al.

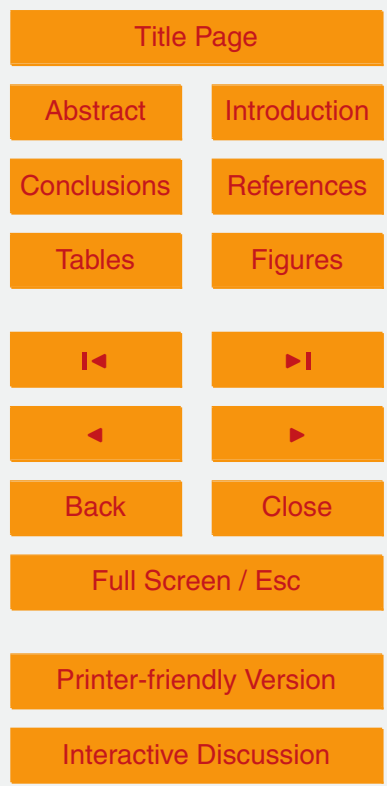


over the period 1961-2006 (Sect. 5, Fig. 1 summarises datasets used). Finally, the robustness of the evaluation to input data and parameters is tested.

The model is forced backwards in line with historical values. A first input data is the evolution of forest area that sets up a "top-down" constraint on the total area of cropland 5 and pasture. Changes in forest area are simply prescribed from Ramankutty and Foley (1999). The evolution of other drivers of the extensification/intensification of agriculture over the past $45 \mathrm{yr}$ are:

- food consumption in caloric units based on Agribiom (Dorin, 2011): Sect. 3.1;

- fertiliser (NPK) prices and consumption values in 2001 based on the World Bank (2012a) and FAO (2012): Sect. 3.2;

- other cropland area and production of other crops, i.e. those non-modelled by LPJmL, based on Agribiom and FAO data: Sect. 3.3;

- differences in fixed cost per hectare between extensive and intensive systems, based on GTAP (2006) and UNSD (2011): Sect. 3.4;

- potential yield evolution induced by changes in irrigated areas, based on LPJmL data: Sect. 3.5;

- changes in feeding practices, based on Bouwman et al. (2005) livestock production model and parameters: Sect. 3.6.

We also present estimates of trade in food crops and ruminant products from Agribiom (Sect. 3.1) and of fertiliser consumption from FAO (Sect. 3.2) since they will be used as forcing variables during a step of the evaluation process (Sect. 4).

\subsection{Food production and trade in calories}

As described in Souty et al. (2012), the global database Agribiom (Dorin, 2011) provides historical resource-use balances in kilocalories (kcal) computed with FAO annual
6, 6975-7046, 2013

Calibration and evaluation of the

Nexus Land-Use

model

F. Souty et al.

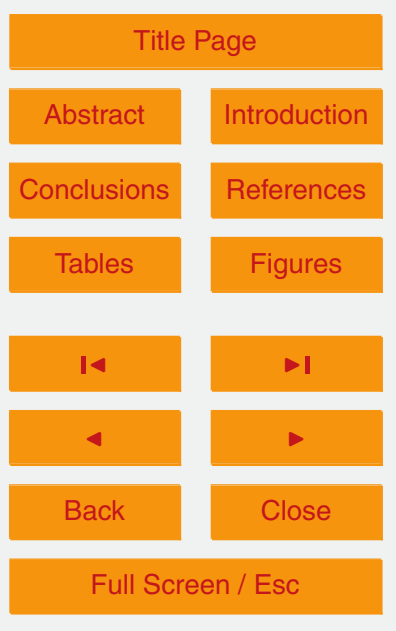

Printer-friendly Version

Interactive Discussion 
country-level supply-utilisation accounts in tonnes. Using additional data, such as human population, Agribiom also estimates food availability (kcal per capita) hereafter called "diets." Over 1961-2006, it shows that average availabilities in plant food increased along with those in animal food (fish and sea food excluded) (Fig. 2) but with

5 large regional differences, and a special case, the Former Soviet Union (FSU). The increase in food availability is particularly remarkable in China, India, Africa and the Rest of Asia, since these regions also witnessed a large increase in population. The following Agribiom estimates were used to force or calibrate Nexus Land-Use over 1961-2006:

10 - human population;

- diets in plant, ruminant and monogastric products (availabilities in kcalcap ${ }^{-1}$ );

- other consumptions of edible plant or animal products (in $\mathrm{kcal} \mathrm{yr}^{-1}$ ): seed, other non-food uses (mainly lubricant and energy) and waste (between farm production and household provision);

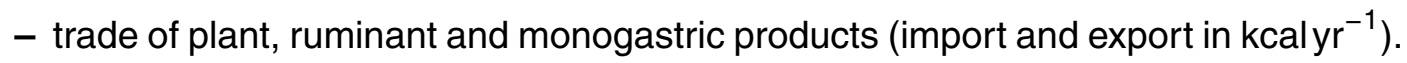

The trade data show that the USA, Canada, Latin America and the Rest of Asia became growing net exporters of plant food calories, while Africa, the Middle East, the OECD Pacific and China became growing net importers between 1961 and 2006 (Fig. 15).

\subsection{Fertiliser price and consumption}

20 Fertilisers are important inputs to increase agricultural production, especially when agricultural land is limited. The FAO (2012) statistical database provides historical annual country fertiliser consumptions in tonnes for various mineral (inorganic) fertilisers, as well as their aggregates in nitrogen $(\mathrm{N})$, phosphate $\left(\mathrm{P}_{2} \mathrm{O}_{5}\right)$ and potash $\left(\mathrm{K}_{2} \mathrm{O}\right)$ equivalents. Figure 3 , shows the regional nitrogen consumptions per hectare of cropland over 1961-2006. The global average increased 8 fold between 1961 and 2006. In
GMDD

6, 6975-7046, 2013

Calibration and evaluation of the

Nexus Land-Use

model

F. Souty et al.

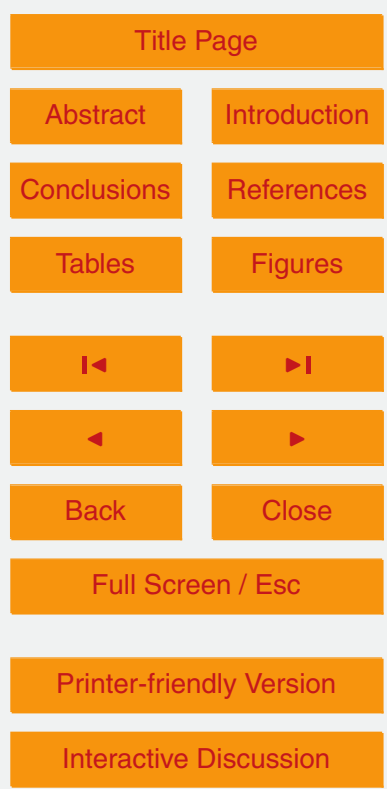


2006, the regional average consumption ranged between $250 \mathrm{~kg} \mathrm{Nha}^{-1} \mathrm{yr}^{-1}$ in China and $10 \mathrm{~kg} \mathrm{Nha}^{-1} \mathrm{yr}^{-1}$ in the Former Soviet Union, where it fell by $78 \%$ between 1988 and 1994 (-22\% in Europe). Phosphate and potash consumption patterns showed no clear regional trends.

The fertiliser price is a determining parameter as it drives the land-fertiliser substitution, and thus strongly influences the intensification level calculated by the model. To obtain price series since 1960, two options were available:

- Using the fertiliser price index provided by the World Bank based on market spot prices of triple super-phosphate, urea, potassium chloride, diammonium phosphate and phosphate rock (World Bank, 2012a).

- Using annual country import and export data of $\mathrm{N}, \mathrm{P}_{2} \mathrm{O}_{5}$ and $\mathrm{K}_{2} \mathrm{O}$ provided by the FAO in quantity (tonnes) and monetary values (current US dollars). To transform these values into constant 2001 US dollars, we use the MUV index (Manufactures Unit Value) of the World Bank (2012a) which is a composite index of prices for manufactured exports from the fifteen major (G-15) developed and emerging economies. At the world level, annual total trade values (sum of imports and exports in 2001-US\$) are then divided by annual quantities (sum of imports and exports in tonnes) for $\mathrm{N}, \mathrm{P}_{2} \mathrm{O}_{5}$ and $\mathrm{K}_{2} \mathrm{O}$ fertiliser in order to obtain price proxies.

The two price series are compared on Fig. 4. The $p_{\chi}^{\mathrm{WB}}$ and the $p_{\chi}^{\mathrm{FAO}}$ provide consistent evolutions from 2006 to 1970, but significantly diverge during the 1960s. A benchmark of our price series with other sources (including oil and gas prices - see Fig. 5) leads us to conclude that $p_{\chi}^{\mathrm{WB}}$ proxy data is more realistic than $p_{\chi}^{\mathrm{FAO}}$. Indeed, the sharp decrease of the FAO fertiliser price index during the 1960s is not confirmed by other data sources. This discrepancy between FAO and World Bank data may be due to the weakness of fertiliser trade in the 1960s as well as the low quality of FAO data on fertiliser in this period. For this reason, we chose the World Bank (2012a) fertiliser price index $\left(p_{\chi}^{\mathrm{WB}}\right)$ smoothed with a Hodrick-Prescott filter (with $\lambda=6.25$, Ravn and Uhlig, 2002) to force retrospective simulations.
GMDD

Calibration and evaluation of the

Nexus Land-Use model

F. Souty et al

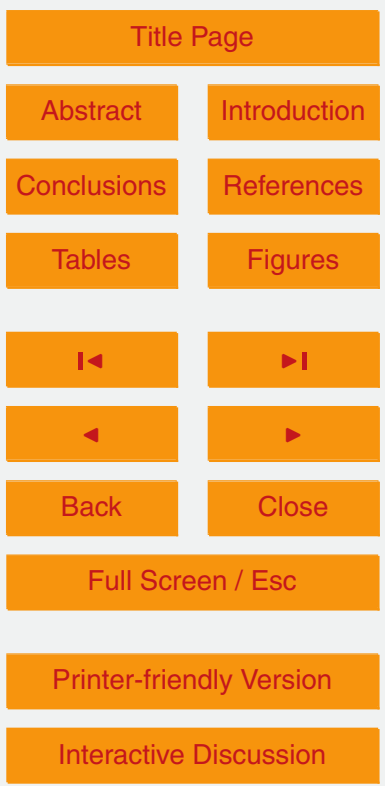


In addition to the change in prices, we also need the cost of fertiliser consumption per region at the base year, $I C_{\chi}$. This value is obtained by multiplying the regional 19992003 averages of trade prices by regional consumptions in tonnes for $\mathrm{N}, \mathrm{P}_{2} \mathrm{O}_{5}$ and $\mathrm{K}_{2} \mathrm{O}$ from $\mathrm{FAO}$ (2012). We then assume that in each region the share of the dynamic 5 crops in these costs is equal to their share in the total production of plant food calories in 2001.

\subsection{Other crop productions and areas}

In the Nexus Land-Use model, there are dynamic crops whose potential yields are given by the LPJmL vegetation model, and other crops that are not. For the base year
- The dynamic crops account for $87 \%$ of the world plant food production in calories (10 $600 \mathrm{Gkcal}$ according to Dorin, 2011) and $51 \%$ of the world cropland area (1500 Mha according to Ramankutty et al., 2008). These dynamic food crops include most cereals, oil-seeds and pulses, plus sugar beet and cassava and three fodder crops: maize (15 Mha harvested in 2000 according to Monfreda et al., 2008), rye grass and sorghum (1 Mha each, Souty et al., 2012, Table 3).

- Other crops account for $13 \%$ of the world plant food production and for $49 \%$ of world cropland area. They includes (i) edible crops not modelled in LPJmL: fruits and nuts (54 Mha), vegetables (44 Mha), sugar cane (20 Mha), oil palm (10 Mha), coffee (10 Mha), tea (2.4 Mha), etc.; (ii) fodder crops: mixed grasses and legumes (65 Mha), alfalfa (20 Mha), etc.; (iii) non-edible crops: fibre (35 Mha), rubber (8Mha), tobacco (4 Mha), etc.; (iv) the so-called remainder.

Estimating how productions and areas of other crops changed over 1961-2006 is challenging. For productions, Agribiom estimates in calories over this period are used but if dynamic and other crops fall into the same Agribiom category, they are split according to FAO data on the harvested area. For example, in 1985, 8 Mha of cassava
GMDD

$6,6975-7046,2013$

Calibration and evaluation of the

Nexus Land-Use

model

F. Souty et al.

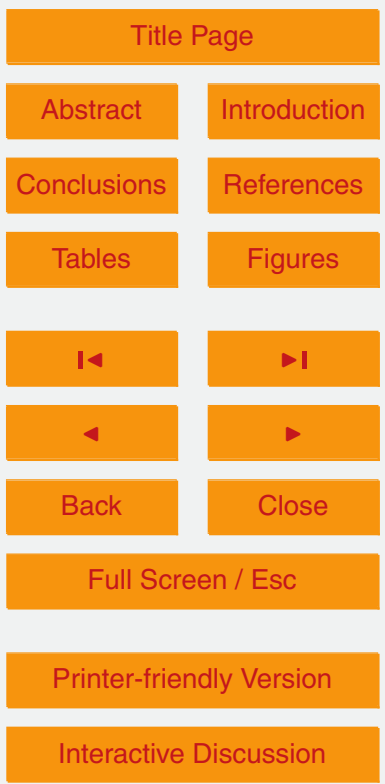


(dynamic crop) and 4 Mha of other roots and tubers were harvested in Africa. Therefore two thirds of the production of the Agribiom category "Roots and Tubers" (other crop) is allocated to dynamic crop production and one third to other crop production for the year 1985.

5 Calculation of changes in cropland areas is problematic. Since the FAO provides only harvested areas, there is no historical data on cultivated area distinguishing the different crops. Cultivated and harvested area may however be quite different as some areas are harvested more than once a year (cropping intensity $>100 \%$ ) or, conversely, set aside as fallow (cropping intensity $<100 \%$ ).

10 To estimate the regional evolution of other cropland areas for which there is no historical data, we subtract an estimation of the evolution of dynamic cropland areas from the Ramankutty and Foley (1999) total cropland area evolution. This estimation is made in each region by multiplying relative changes in the harvested area of dynamic food crops reported by the FAO (2012) by the dynamic cropland area at the base year 2001 15 (coming from LPJmL data) ${ }^{1}$. Our retrospective simulations are forced back in time with the evolution of other cropland area and other food crop productions smoothed with a Hodrick Prescott filter (with $\lambda=6.25$, Ravn and Uhlig, 2002).

Even though it is not used in our retrospective simulations, we decomposed the other cropland area in (i) harvested areas of other food crops reported by the FAO, (ii) other fodder crops by combining the Monfreda et al. (2008) estimation of non LPJmL fodder

\footnotetext{
${ }^{1}$ Estimating changes in cropland area using harvested area, however, is problematic in case of change in cropping intensity. If the number of harvests per year increased from 1961 to 2006 , the reconstruction of cropland area will be underestimated at the begining of the period. For example, if the number of harvests per year decreased from 2 to 1 backward in time, the harvest area is halved, and this signal will be wrongly assumed to represent a halving in cropland areas. In reality, for this example, the cropland area did not change, but the production of crops per hectare and per year was halved. The use of this method, in our case, amounts to converting changes in cropping intensity on dynamic crops in cropland area equivalents and adding these areas to other cropland area. The repartition of dynamic and other cultivated areas is therefore incorrect but their sum is comparable to total cropland area.
}

GMDD

6, 6975-7046, 2013

Calibration and evaluation of the

Nexus Land-Use model

F. Souty et al.

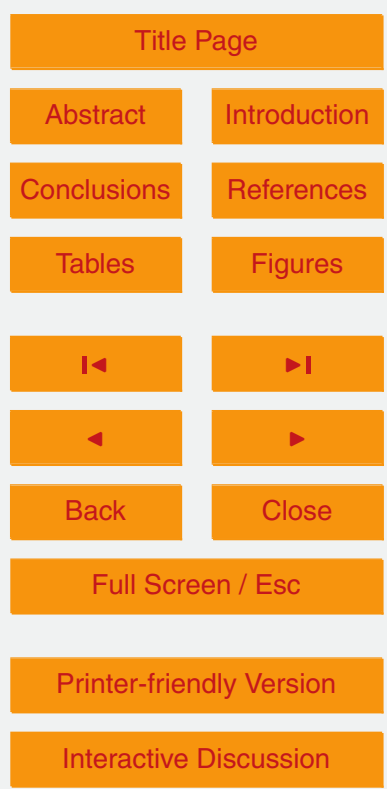


crops harvested area in 2000 and relative changes in fodder consumption from the Nexus Land-Use simulation described in Sect. 5, (iii) the remainder. In addition, the dynamic cropland area is decomposed between food crops and fodder crops using Monfreda et al. (2008) data and relative changes in fodder consumption from the sim5 ulation of Sect. 5 (Fig. 6). Our breakdown of cropland area is imperfect, as shown in Fig. 6. The negative values of remainder area in China after 2003 is probably due to an increase in the number of harvests per year. The negative values in the 1970's in the FSU may be due to an overestimation of cropland area for fodder production.

In this study, the accuracy of retrospective simulations is assessed by comparing 10 Ramankutty and Foley's estimation of historical changes in total cropland areas with model outputs. One must keep in mind, however, that other cropland areas are exogenously set which means that, in practice, only changes in dynamic cropland areas are evaluated against Ramankutty and Foley's observed changes in cropland areas.

\subsection{Fixed cost (labour and capital)}

This section describes the computation of variations in the fixed cost for labour and capital $\left(\mathrm{FC}_{\text {tot }}\right)$. In the Nexus Land-Use, $\mathrm{FC}_{\text {tot }}$ is used to compare the opportunity cost of the intensive and extensive systems. It can be interpreted either as the difference between the fixed cost per hectare in the extensive and intensive systems, or as the fixed cost in the intensive system, considering that the cost is negligible in the extensive one. Indeed, the extensive system produces only ruminants that are fed by grazing while the intensive system produces ruminants, monogastrics and food crops.

The fixed cost of production in the intensive system corresponds to all expenditures of farmers used for crop and livestock production except the intermediary consumption of fertilisers and pesticides. This cost includes labour, capital, other intermediary of the extensive production system is significantly lower since breeding livestock fed by grazing only includes some labour and few infrastructure/facilities (Souty et al., 2012, p. 1310-1311).

Calibration and evaluation of the

Nexus Land-Use model

F. Souty et al.

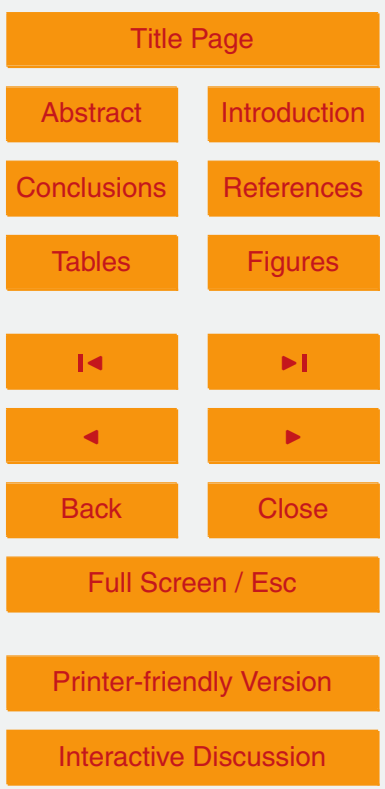

Interactive Discussion 
$\mathrm{FC}_{\text {tot }}$ is calibrated at the base year 2001 , so as to ensure that the cost minimisation of agricultural production leads to a position of the production frontier that fits with the distribution of agricultural area in 2001 (Souty et al., 2012). There are no primary economic data distinguishing between an extensive and an intensive system. However, 5 the evolution of this differential cost should follow the evolution of the main cost items in the dynamic cropland sector, the whole intensive sector or the whole agricultural sector.

Very little data is available to estimate historical changes in $\mathrm{FC}_{\text {tot }}$, which leads to several assumptions before computing the regional evolution index of $\mathrm{FC}_{\text {tot }}$. Firstly, due to 10 a lack of data on other intermediary consumption like business services and on-farm energy consumption, it is assumed that this cost item evolves as labour and capital. Labour and capital costs in the intensive system are estimated by subtracting the land rent per hectare $(\lambda)$ from the added value per hectare of the intensive system (VA). Evolution of the cropland area is taken from Ramankutty and Foley (1999). The values of both VA and $\lambda$ in 2001 for dynamic crops are taken from the GTAP (2006) database. Since no difference is made between intensive and extensive livestock farming in the GTAP database, we selected only the GTAP categories corresponding to dynamic crops (Souty et al., 2012, p. 1316). This amounts to neglecting differences in fixed costs between the intensive and extensive sectors that are not associated with staple crops. Changes in VA were estimated by using the added value per hectare of cropland of the "Agriculture, hunting, forestry, fishing" sector from the UNSD (2011), considering that the part of the agricultural sector corresponding to dynamic crops evolved as the whole agricultural sector. Changes in $\lambda$ are more difficult to estimate, and we assumed that the evolution of this land rent per hectare is related to land scarcity change, and that land scarcity is related to the population per hectare of cropland. By subtracting $\lambda$ from VA, the evolution of labour and capital during the period 1970-2006 was inferred (data on VA not being available before 1970, labour and capital is considered constant during the 1961-1970 period). In retrospective simulations, $\mathrm{FC}_{\text {tot }}$ is forced by changes
GMDD

Calibration and evaluation of the

Nexus Land-Use model

F. Souty et al.

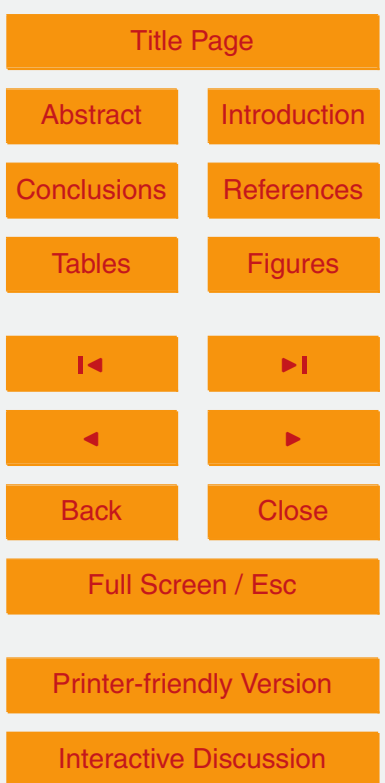


in labour and capital smoothed with a Hodrick Prescott filter (with $\lambda=6.25$, Ravn and Uhlig, 2002). The evolution of $\mathrm{FC}_{\text {tot }}$ is shown in Fig. 7.

\subsection{Potential yield}

The yearly increase in crop production per hectare over the past five decades can be 5 attributed to irrigation, fertilisers and improved crop varieties, which altogether allow for an increase of yield, a reduction of fallow, or an increase in the number of harvests per year. In the Nexus Land-Use model, fertiliser and pesticide consumption is endogenously modelled. Changes in the number of harvests per year can be modelled by the forced evolution of other cropland area. The impact of changes in irrigation is modelled 10 through changes in potential yields.

The impact of high yielding varieties is not accounted for per se but through increase in fertiliser use, because these varieties are considered to respond better to fertiliser than traditional ones and make it possible to reach higher yields (Evenson and Gollin, 2003). We therefore consider that genetic improvements allowed to improve stress resistance, but not to push out the yield frontier (Cassman, 1999). Nevertheless, the better productivity of newly introduced varieties also results from their higher harvest index (i.e. these plants devote much of their fixed carbon to producing grain and less to producing straw or leaf material, see Hay, 1995). Due to lack of regional data, and because it is unclear to what extent a higher harvest index depends on increases in fertilisers, this effect is not taken into account.

The impact of irrigation on yield is inferred using the rainfed and irrigated variants of LPJmL potential yields. Changes in potential yields due to irrigation are calculated backwards in time from 2001 using annual fractional coverage per grid cell of each crop functional type separately for irrigated and rainfed areas from Fader et al. (2010) (the same computation is made from 2001 to 2006, Figs. 8 and 9). Changes in potential yields are smoothed with a Hodrick Prescott filter (with $\lambda=6.25$, Ravn and Uhlig, 2002). Smoothed relative changes in potential yield are applied to the potential yield of each land class $\left(\rho_{j}^{\max }\right.$, Eq. A2). Major increases of potential yield attributed to increased

Calibration and evaluation of the Nexus Land-Use model

F. Souty et al.

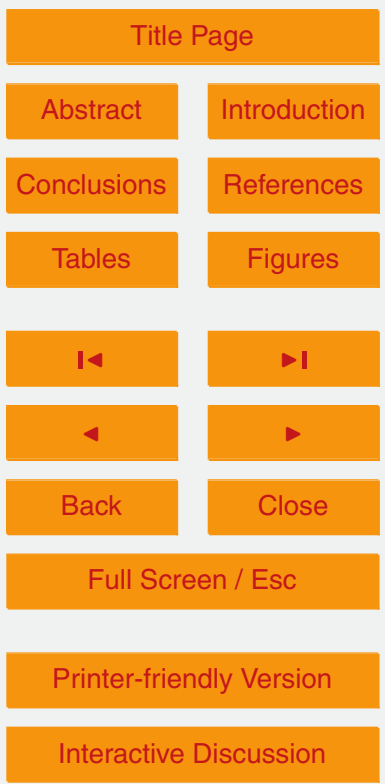


irrigation from 1961 to 2006 are $26 \%$ in China, $18 \%$ in India, $11 \%$ in the Middle East, $7 \%$ in the Rest of Asia.

\subsection{Livestock production model}

As described in Souty et al. (2012) Sect. 3.3, feed requirements for animal production 5 is calculated using the Bouwman et al. (2005) dataset. This dataset considers monogastrics (non-grazing animals), ruminants in the extensive system fed by grazing only and ruminants in the intensive system fed by grass, food crops, residues and fodder, animal products and product scavenging. For each category, Bouwman et al. (2005) gives a feed conversion factor defined as the calories of feed needed to produce one calorie of animal food $(\beta)$, and feed composition factors defined as the share of each specific feed product in total feed needs $(\phi)$. Bouwman et al. (2005) only report values of $\beta$ and $\phi$ for 1970, 2000 and 2030. Hence, in retrospective simulation, we assumed a linear evolution of these factors between these three dates.

Regarding $\beta$ values, from 1970 to 2000 , Bouwman et al. (2005) shows that the quantity of feed to produce a calorie of ruminant product in the intensive system, $\beta_{\text {rint }}$, decreased by $74 \%$ for China and $50 \%$ for India and the Rest of Asia. This trend likely reflects an increasing carcass weight, off-take rates, milk production per animal and a decrease in the use of animal traction (Bouwman et al., 2005, p. 146). The feed conversion factor for monogastrics, $\beta_{\mathrm{m}}$, decreased by $13 \%$ for India and by $36 \%$ for China. Regarding $\phi$ values, the share of food crops (soybean cakes, maize grain, etc.) in the feed ration of intensive ruminants, $\phi_{\mathrm{r}, \mathrm{int}}^{\mathrm{fc}}$, increased for all regions except Brazil where it decreased from $15 \%$ in 1970 to $2 \%$ in 2000 . The largest increase of $\phi_{\text {r,int }}^{\mathrm{fc}}$ took place over China and the Rest of Asia, where it climbed from $2 \%$ in 1970 to $10 \%$ in 2000, and over the Middle East (from 7\% to $29 \%$ ). The Bouwman et al. (2005) dataset was also used to infer trends in the yield of intensive and extensive grasslands (see Sect. 4.4).

Calibration and evaluation of the Nexus Land-Use model

F. Souty et al.

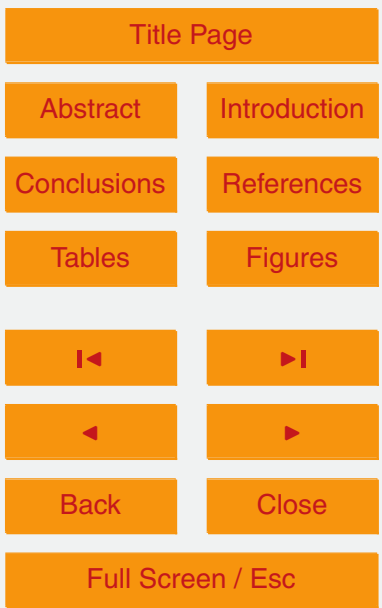

Printer-friendly Version

Interactive Discussion 


\section{Results: calibration and evaluation of specific model components}

In the following, the performances of the Nexus Land-Use model are assessed using model-data root-mean-square errors (RMSE) and the coefficients of variation of RMSE (CV(RMSE)). The RMSE of the variable $X$ in the region $k$ is defined by $5 \sqrt{\frac{1}{T} \sum_{t}\left(X_{k, t}^{\text {model }}-X_{k, t}^{\text {obs }}\right)^{2}}$, where $X_{k, t}^{\text {model }}$ and $X_{k, t}^{\text {obs }}$ are the simulated and observed values of $X$ at the year $t$ and $T$ is the number of years of the period. RMSE at the world level is $\sqrt{\frac{1}{T} \sum_{k, t}\left(X_{k, t}^{\text {model }}-X_{k, t}^{\text {obs }}\right)^{2}}$. The coefficient of variation of RMSE is $\frac{\sqrt{\frac{1}{T} \sum_{t}\left(X_{k, t}^{\text {model }}-X_{k, t}^{\text {obs }}\right)^{2}}}{\frac{1}{T} \sum_{t} X_{k, t}^{\text {obs }}}$ at the regional level and $\frac{\sqrt{\frac{1}{T} \sum_{k, t}\left(X_{k, t}^{\text {model }}-X_{k, t}^{\text {obs }}\right)^{2}}}{\frac{1}{T} \sum_{k, t} X_{k, t}^{\text {obs }}}$ at the world level. To facilitate the reading, RMSE and CV(RMSE) are denoted with the name of the variable in superscript and the 10 period in subscript. For example, RMSE on cropland area over the 1961-2006 period is denoted RMSE ${ }_{1961-2006}^{\text {cropland }}$

\subsection{Crop yield function of input in each land class of each region}

As described in Souty et al. (2012) Sect. 3.2, in each land class of each region, the yield of the dynamic croplands is an increasing function of agricultural input consumption (mainly fertiliser and pesticide). This function exhibits decreasing returns and asymptotes toward the potential yield of its land class, $\rho_{k, j}^{\max }$. In each land class $j$, the minimum yield, $\rho_{k, j}^{\min }$, corresponding to the yield without inputs, is defined as a fixed fraction of the potential yield. In the first version of the model, this minimum in each land class $R_{\max k}^{\min }=\rho_{k, j}^{\min } / \rho_{k, j}^{\max }$ was set at $10 \%$ in each region and each land class because ob20 served actual yields in Africa - which are thought to be close to the minimum yield reach $10 \%$ of the potential yield (Souty et al., 2012, p. 1306). To refine this assumption, in this study we recalibrated the minimum yield by minimising the error between simulated and observed dynamic crop yields.

Calibration and evaluation of the

Nexus Land-Use model

F. Souty et al.

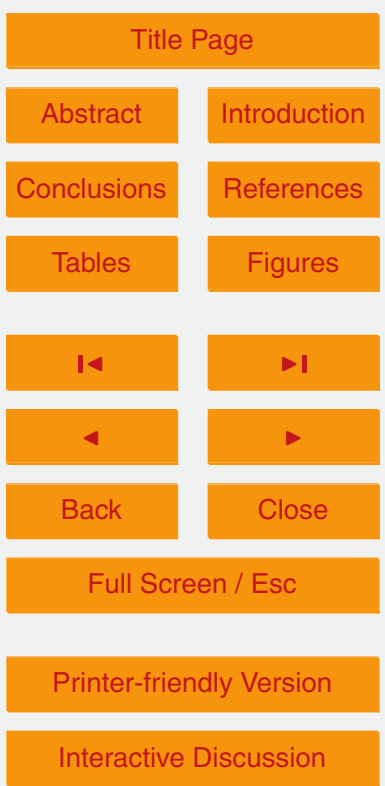


To calibrate and then to evaluate the accuracy of the crop yield function, we used a special version of the model for which no cost optimisation is performed. In that setting, the yield of dynamic cropland in each land class is still a function of fertiliser use ( $\mathrm{IC}_{j}$, the intermediary consumption of the land class $j$, Souty et al., 2012, Eq. 13) 5 but $\mathrm{IC}_{j}$ is no longer the result of a cost minimisation balancing the price of chemical inputs with the food crop calorie price (Souty et al., 2012, Eq. 21). Assuming that the consumption of nitrogen fertiliser is a good proxy for the consumption of all agricultural inputs, $I$ is forced with the relative $\mathrm{FAO}$ nitrogen fertiliser consumption per hectare (Fig. 3 in Sect. 3.2).

10 To isolate the simulated effect of increasing fertiliser consumption on crop yield, the Ricardian production frontier representing cropland expansion on less fertile land is set exogenously. Since historical data on the evolution of the production frontier is not available, it is fixed at its 2001 level. In this configuration, the model is over constrained. The repartition between intensive and extensive livestock production systems cannot evolve to match the prescribed land supply. Therefore the demand for agricultural land does not equal this prescribed land supply. Even though a physical constraint is not met, it is not problematic since we are focussing here on the relationship between dynamic crop yield and fertiliser use.

This configuration lets us see how minimum and potential yields influence the results of the model. A sensitivity analysis is performed by using 7 values of potential yield from -40 to $40 \%$ of the original value of $\rho_{j}^{\max }$, and 9 values of the minimum to potential yield ratio from 10 to $50 \%$. These values were modified so that potential yields would be no less than $105 \%$ of actual yields and minimum yields no more than $95 \%$ of actual yields. The minimum $R_{\max k}^{\min }$ value is set at $10 \%$, as the literature suggests it cannot be lower 25 (Seufert et al., 2012; Erb et al., 2009, p. 17). Since the base year of the model is 2001, in retrospective simulations, the model is run from 2001 to 1961 and from 2001 to 2006. $\mathrm{RMSE}_{1961-2006}^{\text {dyn. cropland }}$ is calculated by comparing, in each region, the simulated changes of dynamic cropland areas to the observed ones (Sect. 3.3).
GMDD

Calibration and evaluation of the

Nexus Land-Use model

F. Souty et al.

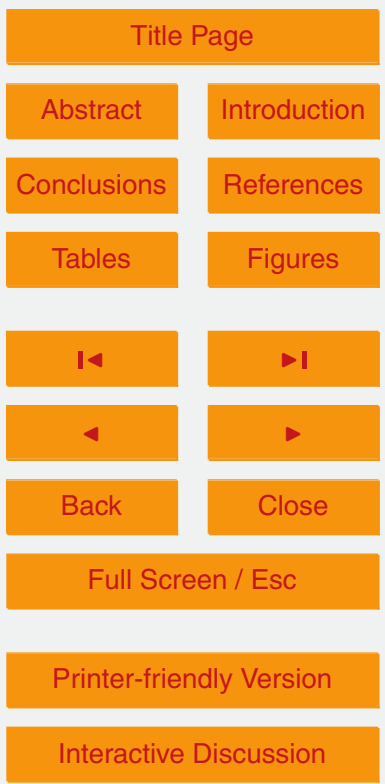


The results show that the RMSE ${ }_{1961-2006}^{\text {dyn. cropland }}$ is very sensitive to the minimum and potential yields levels. The model performance is also region-dependent. When the difference between minimum and potential yields decreases, the RMSE ${ }_{1961-2006}^{\text {dyn. cropland }}$ diminishes in the OECD Pacific and the Former Soviet Union regions, and increases in

5 Europe, China and the Rest of Latin America. For other regions, the dynamic cropland area is less sensitive to potential yield levels, and minimum yield levels minimising the $\mathrm{RMSE}_{1961-2006}^{\text {dyn. cropland }}$ lie in median values. The reason why the OCDE Pacific and the FSU show similar patterns may be their specific form of yield evolution since 1961, which did not increase monotonically with nitrogen fertiliser consumption per hectare (Fig. 10).

10 Beside reproducing the evolution of yields between 1961 and 2006, we also want to reproduce a response to fertiliser inputs that is not too different across regions. Indeed, Ladha et al. (2005) and Van Groenigen et al. (2010) have shown that the response of major cereals yield as a function of nitrogen are similar across regions. For this reason, we do not calibrate $R_{\max k}^{\min }$ just by minimising the $\mathrm{RMSE}_{1961-2006}^{\text {dyn. cropland }}$. We used a customed error term (Eq. 1) which also takes into account the difference between a world reference $s_{\min }^{\text {ref }}$ and the regional initial slope of the yield response to fertilisers, $s_{\min k}=\frac{P_{k}^{\mathrm{NPK}}}{\alpha_{I C k}}$, with $P_{k}^{\mathrm{NPK}}$ the price of fertiliser at the base year calculated in Sect. 3.2, and $\alpha_{\mathrm{IC} k}$ (in $\mathrm{kcal}^{-1}$ ) the initial slope of the production function, in monetary value terms (Souty et al., 2012, p. 1316).

20 $R_{\max k}^{\min }=\operatorname{argmin}\left(\frac{W}{T} \sum_{t=0}^{T} \frac{\left(\operatorname{Sdyn}_{k, t}^{\operatorname{model}}\left(R_{\max k}^{\min }\right)-\operatorname{Sdyn}_{k, t}^{\mathrm{obs}}\right)^{2}}{\operatorname{Sdyn}_{k, t}^{\mathrm{obs}^{2}}}+\frac{\left(S_{\min k}\left(R_{\max k}^{\mathrm{min}}\right)-S_{\min }^{\mathrm{ref}}\right)^{2}}{S_{\min }^{\mathrm{ref}}{ }^{2}}\right)$

$\operatorname{Sdyn}_{k, t}^{\text {model }}$ and $\operatorname{Sdyn}_{k, t}^{\text {obs }}$ are the simulated and observed areas of dynamic crops in the region $k$ at the year $t$. The $s_{\min k}$ value depends on $R_{\max k}^{\min }$ because it is calibrated at the base year 2001 (Souty et al., 2012, p. 1316). $s_{\min }^{\text {ref }}$ is $107 \mathrm{Mkcal}(\mathrm{kgNPK})^{-1}$ and was determined using a first estimation of $R_{\max k}^{\min }$ found by minimising only the dynamic 6994
GMDD

Calibration and evaluation of the

Nexus Land-Use

model

F. Souty et al.

\section{Title Page}

Abstract Introduction

Conclusions

Tables

References

Figures

14

4

Back

Full Screen / Esc

Printer-friendly Version

Interactive Discussion 
cropland RMSE (Appendix C1). $W$ is a weight manually tuned in order to obtain satisfying results. Its value has been set to $10^{-3}$ in order to have a correct tradeoff between minimising the error on simulated crop yield in the future and avoiding large differences in the response of yields to fertiliser. Because estimates of potential yields by LPJmL 5 seems exceedingly high, the Middle East's potential yield is reduced by $30 \%$ in each land class to be consistent with values observed in other regions (Fig. 10 shows modified value).

Calibrated $R_{\max k}^{\min }$ vary from 10 to $35 \%$ between regions (Table 2). Figure 10 shows the simulated dynamic cropland yields for calibrated $R_{\max k}^{\min }$ as a function of nitrogen fer10 tiliser consumption from the FAO (2012). It is compared with observed dynamic cropland yields. The potential yield is also shown for information in Fig. 10. The model is used in its "no cost minimisation version" from 1961 to 2006. Despite some exceptions, Nexus Land-Use fits rather well with observations, showing that the shape of our production function is adequate to reproduce historical yield trends. In absolute terms, the $15 \mathrm{RMSE}_{1961-2006}^{\text {dyn. cropland }}$ is larger than $10 \mathrm{Mhayr}^{-1}$ for Europe, India and the Former Soviet Union, and lower for other regions. In relative terms, the CV(RMSE) ${ }_{1961-2006}^{\text {dyn. cropland }}$ is below $20 \% \mathrm{yr}^{-1}$ except for the FSU, the OECD Pacific and the Middle East regions.

$\alpha_{\mathrm{IC} k}$ ranges from 1.2 to $2.4 \$ \mathrm{Mkcal}^{-1}$ except for the OECD Pacific and the Middle East, where it is respectively 4.1 and $4.5 \$ \mathrm{Mkcal}^{-1}$, meaning that it is more costly to 20 increase yield in these regions (Table 2). $\frac{P_{k}^{\mathrm{NPK}}}{\alpha_{I C K}}$, which mirrors fertiliser use efficiency in volume over the 1961-2006 period, ranges from 60 to $132 \mathrm{Mkcalt}^{-1}$. It is the lowest in the Middle East and the highest in the USA.

In the OECD Pacific, the observed yield does not increase as a monotonic function of nitrogen fertiliser consumption due to the confounding effects of specific agricultural reported by the FAO were not always positively correlated with fertiliser use. For example, the yield of rice increased by 11\% in Japan between 1970-1980 and 2000-2006 while the nitrogen fertiliser consumption per hectare decreased by $14 \%$. Similarly,

GMDD

$6,6975-7046,2013$

Calibration and evaluation of the

Nexus Land-Use

model

F. Souty et al.

Title Page

Abstract

Conclusions

Tables Introduction References Figures

14

4

Back

Close

Full Screen / Esc

Printer-friendly Version

Interactive Discussion $\rightarrow$ I

$>$ 
fertiliser consumption is poorly correlated with yield in the Former Soviet Union. Between 1987 and 1994, because of the collapse of the centrally planned economy, the nitrogen fertiliser consumption per hectare decreased by $80 \%$ while the observed $d y$ namic cropland yields decreased only by $20 \%$. Then, between 1994 and 2003, the 5 dynamic cropland yields increased by $30 \%$ while the nitrogen fertiliser consumption per hectare continued to decrease by $40 \%$.

In the following, we used calibrated values of $\rho_{j}^{\min }$ and the Middle East's $\rho_{j}^{\max }$ cut down by $30 \%$ compared to the original LPJmL data. The model is used in its "classical" version for which fertiliser use and the Ricardian production frontier are solved to minimise the production cost of the agricultural product.

\subsection{International trade module}

In the Nexus Land-Use model, the international trade of food crop products is modelled as follows:

$\operatorname{Imp}_{k}^{\mathrm{fc}}=\alpha_{k}^{\mathrm{fc}, \mathrm{imp}} \times \frac{p_{\mathrm{cal}_{k}}}{p_{\mathrm{cal}}^{\mathrm{w}}} \times D_{k}^{\mathrm{fc}}$

$15 \operatorname{Exp}_{k}^{\mathrm{fc}}=\frac{\alpha_{k}^{\mathrm{fc}, \exp } p_{\mathrm{cal}_{k}}^{-\gamma^{\mathrm{fc}}}}{\sum_{k} \alpha_{k}^{\exp , \mathrm{fc}} p_{\mathrm{cal}_{k}}^{-\gamma^{\mathrm{fc}}}} \times \sum_{k} I m p_{k}^{\mathrm{fc}}$

where $D_{k}^{\mathrm{fc}}$ is the demand for food crops (fc subscript) in the region $k$ in calories, $p_{\text {cal }}$ the regional food crop calorie price and $p_{\text {cal }}^{\mathrm{w}}$ the world food crop calorie price. $\alpha_{k}^{\mathrm{fc}, \mathrm{imp}}$ and $\alpha_{k}^{\mathrm{fc}, \exp }$ are calibrated at the base year 2001 using trade data from Agribiom (Dorin,

2011). $\gamma^{\text {fc }}$ is the price elasticity of exports of food crops which was arbitrarily set at $2 \%$ in the first version of the model. International trade of ruminant products is modelled in the same manner using the price of ruminant calories $p_{\mathrm{r}}$ and parameters $\alpha_{k}^{\text {r,imp }}, \alpha_{k}^{\text {r,exp }}$ and $\gamma^{r}$. Trade of monogastric products is prescribed (Souty et al., 2012, p. 1313).
6, 6975-7046, 2013

Calibration and

evaluation of the

Nexus Land-Use

model

F. Souty et al.

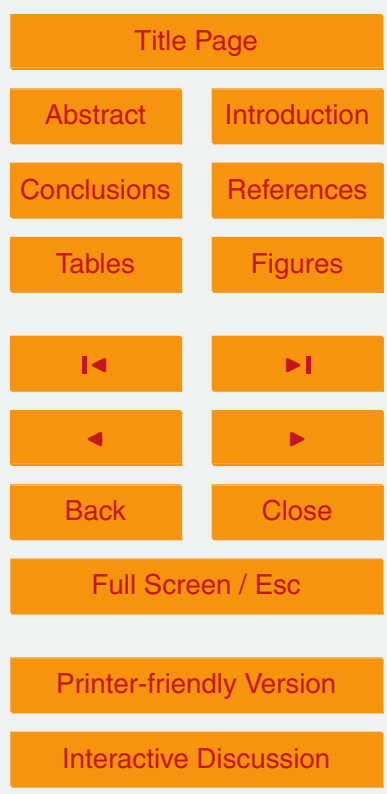

Interactive Discussion 
Between 1961 and 2006, the volume of food crop trade grew from $10 \%$ to $23 \%$ of the world food crop production. Trade in ruminant products took in parallel an increasing fraction of world ruminant production, going from $9 \%$ to $16 \%$. To reproduce these historical changes in the share of trade in total production, import coefficients $\alpha_{k}^{\mathrm{fc} \text {,imp }}$ for 5 food crops and $\alpha_{k}^{\text {r,imp }}$ for ruminants were modified during runs of the model using an annual evolution rate. An evolution rate of $1 \%$ means that $\alpha_{k}^{\mathrm{fc}, \mathrm{imp}}$ and $\alpha_{k}^{\mathrm{r} \text {,imp }}$ coefficients increase by $1 \%$ per year from 2001 to 2006 and decrease by $1 \%$ per year from 2001 to 1961 backward in time. Imports and exports of monogastric products are forced by the evolution rate of $\alpha_{k}^{\text {r,imp }}$.

10 In this section, four trade parameters are calibrated at the world level: the evolution rates of import coefficients for food crops $\alpha_{k}^{\mathrm{fc}, \text { imp }}$ and ruminant products $\alpha_{k}^{\text {rimp }}$ and trade elasticities $\gamma^{\mathrm{fc}}$ and $\gamma^{\mathrm{r}}$. To do so, we ran a sensitivity analysis with 4 values of $\alpha_{k}^{\mathrm{fc}, \mathrm{imp}}$ and $\alpha_{k}^{\text {rimp }}$ evolution rates: $1 \%, 2 \%, 3 \%$ and $4 \%$ per year, 8 values for $\gamma^{\text {fc }}$ from 0.5 to 4 and 4 values for $\gamma^{r}$ from 0.5 to 2 . Assessment of results is based on different 5 root-mean-square errors calculated over the period 1980-2006, considering that international trade was too limited before 1980 (the error calculation is detailed in Sect. C2). The global evolution rates of $\alpha_{k}^{\text {fc,imp }}$ and $\alpha_{k}^{\text {r,imp }}$ were chosen to minimise the RMSE on the total trade volumes and imports. The resulting optimised values were found to be of $3 \%$ per year for food crops, and $2 \%$ per year for ruminants products. Using calibrated 20 values of $\alpha_{k}^{\text {fc,imp }}$ and $\alpha_{k}^{\text {r,imp }}$ evolution rates, sensitivity of the model to price elasticity of exports was assessed using the error on net imports by region defined in Table 4. For Europe, the OECD Pacific, China, India, Brazil and Africa, the error on net trade of food crops increases with the elasticity value. the USA have an optimal elasticity value of $3 \%$, while the last five regions show little sensitivity to price elasticity of food crop exports. Concerning trade of ruminant products, except for the USA where the error is lowest for $\gamma^{r}=1$, regional errors either show little sensitivity to price elasticity (7 regions) or increase with the elasticity value (4 regions).

GMDD

6, 6975-7046, 2013

Calibration and evaluation of the

Nexus Land-Use

model

F. Souty et al.

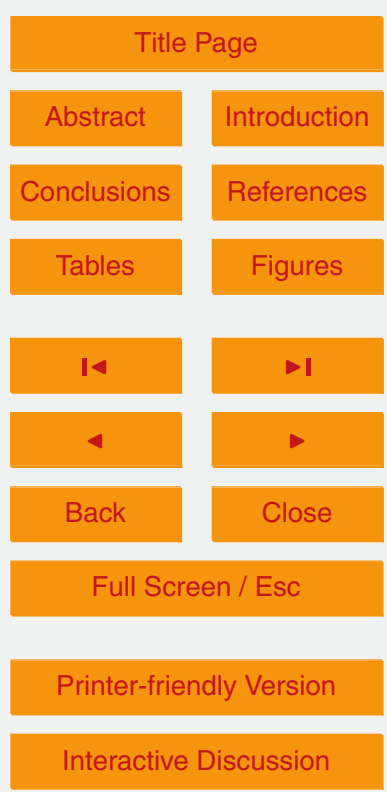


Globally, the error in net trade is lowest for $\gamma^{\mathrm{fc}}=0.5$ and $\gamma^{r}=0.5$. Notwithstanding, errors are quite similar for $\gamma^{\mathrm{fc}}=1(+7 \%)$ and $\gamma^{r}=1(+8 \%)$. With such similar errors, choosing a specific value is rather arbitrary. The food crop market is known to be more reactive than the ruminant meat market, notably due to lower transportation costs $\left(\gamma^{r}<\right.$ ${ }_{5} \gamma^{\mathrm{fc}}$, Hertel and Tsigas, 1988). For this reason, we chose $\gamma^{\mathrm{fc}}=1$ and $\gamma^{r}=0.5$.

\subsection{Maximal conversion speed of residual pastures}

In the example of model outputs presented in Souty et al. (2012), the Maximal Conversion Speed of Residual Pastures (MCSRP) was arbitrarily set at $20 \%$. In this section we assess the impact of this parameter on model results to calibrate the MCSRP.

10 Residual pastures are located on high-yield land classes but are part of the extensive system (no input and grazing only). Considered to be an inefficient use of land from the point of view of economic return (Souty et al., 2012, p. 1309), areas of residual pastures are reduced as soon as the pressure on agricultural land - measured by variations of the production frontier $j_{\text {limit }}-$ is higher than its reference level in 2001 . The 15 annual conversion speed is linearly related with the pressure on land up to the MCSRP value. Therefore, if MCSRP $=20 \%$, when $j_{\text {limit }}=1,20 \%$ of residual pastures are converted to dynamic cropland and intensives pastures. This share diminishes linearly until $j_{\text {limit }}$ is equal to its reference level in 2001 and no residual pastures are converted. In the same manner, increases in $j_{\text {limit }}$ induce conversions of dynamic croplands and 20 intensive pastures into residual pastures.

A sensitivity analysis was carried out with 28 values for MCSRP: $1,2,3, \ldots, 18$, $19,20,30,40, \ldots, 80,90$ and $100 \%$ (MCSRP $=0 \%$ was not considered because this would come down to suppressing the process). At the regional level, the reconstructed change of cropland area is quite sensitive to the MCSRP value. The most sensitive 25 region is India, for which CV(RMSE) ${ }_{1961-2006}^{\text {cropland }}$ is $\% \mathrm{yr}^{-1}$ for MCSRP $=1 \%$ and $9 \% \mathrm{yr}^{-1}$ for MCSRP $=100 \%$. For USA, Europe, the OECD Pacific, and the Rest of Asia, the error on cropland area decreases with MCSRP while it increases for other regions. At the
GMDD

6, 6975-7046, 2013

Calibration and evaluation of the

Nexus Land-Use model

F. Souty et al.

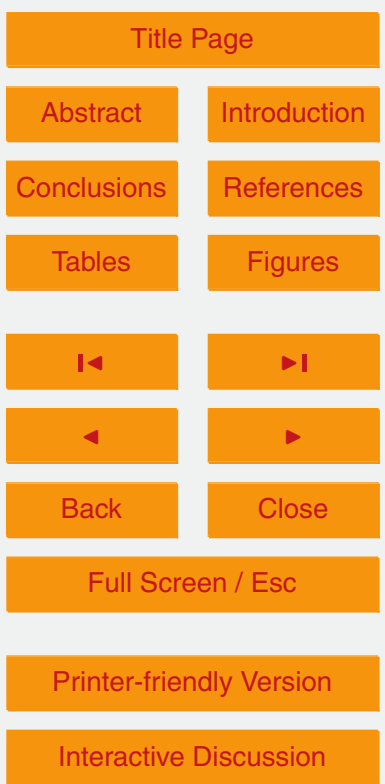


world level, the RMSE ${ }_{1961-2006}^{\text {cropland }}$ is much less sensitive: CV(RMSE) ${ }_{1961-2006}^{\text {cropland }}$ is $4 \% \mathrm{yr}^{-1}$ with MCSRP $=1 \%$ and $5 \% \mathrm{yr}^{-1} \mathrm{MCSRP}=100 \%$. We chose MCSRP $=1 \%$.

\subsection{Grassland yield}

In the Nexus Land-Use model, areas of pastures in intensive and extensive systems 5 (the latter including extensive and residual pastures) are calculated using a "consumed grass yield" for each system in each region $\left(\rho_{\text {past,int }}^{\text {grass }}\right.$ and $\rho_{\text {past,ext }}^{\text {grass }}$ Mkcalha ${ }^{-1} \mathrm{yr}^{-1}$, Souty et al., 2012, p. 1317). These parameters, which correspond to the quantity of grass harvested or grazed (as opposed to total grass grown) on a unit of land, are calibrated at the base year by combining the Bouwman et al. (2005) and Ramankutty et al.

10 (2008) datasets. In this section, we compare these top-down estimations of consumed grass yields to the independent grassland yield estimation from the process-based ecosystem model ORCHIDEE (Krinner et al., 2005).

The ORCHIDEE model was run on a $0.5^{\circ} \times 0.5^{\circ}$ grid without nitrogen limitation using a C3/C4 map based on Collatz et al. (1998), see Fig. 11. In each region, average above 15 and below ground Net Primary Productivity (NPP in $\mathrm{gC} \mathrm{day}^{-1} \mathrm{~m}^{-2}$ ) over the 1995-2004 period were calculated by distinguishing extensive pastures from intensive and residual ones (the latter cannot be separated because they belong to the same land classes). Figure 12 shows that in most regions, the consumed grass per hectare used in Nexus Land-Use is lower than the above ground NPP calculated by ORCHIDEE. Except in the intensive system of India where pasture areas are relatively small (4 Mha) and in the Rest of Asia (12 Mha), the Nexus Land-Use grass yields respect the biophysical constraint provided by the ORCHIDEE simulation.

Calibration and evaluation of the

Nexus Land-Use model

F. Souty et al

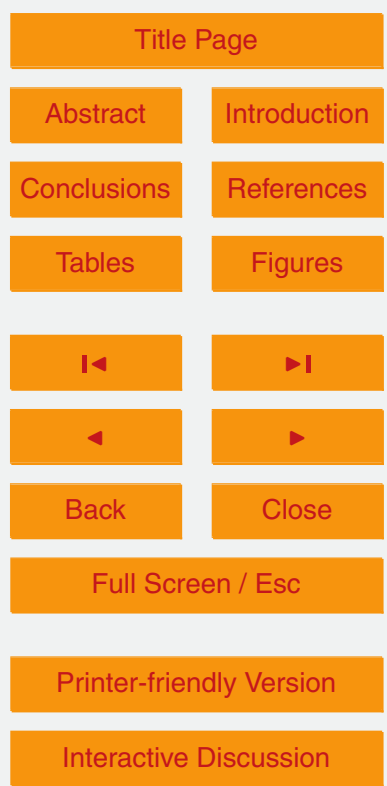




\section{Results: evaluation of the Nexus Land-Use model to reproduce historical changes of cropland areas}

Using the parameters calibrated in the previous section, the performances of the model are now investigated through a backcasting exercise over 1961-2006. Estimations of 5 cropland areas (areas for dynamic and other crops), trade of food crops and ruminant products, food prices and fertiliser consumption in each region are evaluated against historical data in each region. Data sources are Ramankutty and Foley (1999) for cropland areas, Dorin (2011) for trade, World Bank (2012a) for food prices and the FAO (2012) for fertiliser consumption.

10 According to Ramankutty and Foley (1999), the global cropland area increased by $9 \%$ between 1961 and 2006. Regionally, it decreased by $15 \%$ in Canada, Europe and the FSU. It increased by $20 \%$ in the Middle East and in the Rest of Latin America, by $50 \%$ in Africa and the Rest of Asia and doubled in Brazil. Pasture area decreased or remained constant in most of the regions. However, in Brazil and China it increased respectively by $36 \%$ and $70 \%$. The large decline in the Middle East pasture area from 88 Mha in 2004 to 66 Mha in 2005 seems to be due to the removal of pastures in the national inventory of Iran (Fig. 13).

Cropland area changes resulting from the backcasting simulation are shown in Fig. 13. The model performs rather well considering the large changes in food consumption that occured in the last decades (food crops consumed by humans and animals increased 2.5 fold from 1961 to 2006). As expected, results are better over the 1980-2006 period, as CV(RMSE) ${ }_{1980-2006}^{\text {cropland }}$ do not exceed $13 \% \mathrm{yr}^{-1}$. Globally, CV(RMSE) ${ }_{1980-2006}^{\text {cropland }}$ is $2 \% \mathrm{yr}^{-1}$ and CV(RMSE) ${ }_{1961-2006}^{\text {cropland }}$ is $4 \% \mathrm{yr}^{-1}$ (Table 3 ). Over the whole period, the largest $\mathrm{RMSE}_{1961-2006}^{\mathrm{cropland}}$ is for China with $37 \mathrm{Mhayr}^{-1}$. Then four regions show errors between 10 and $28 \mathrm{Mhayr}^{-1}$ and seven other regions are below $7 \mathrm{Mhayr}^{-1}$. In relative terms, the CV(RMSE) ${ }_{1961-2006}^{\text {cropland }}$ is between 11 and $25 \% \mathrm{yr}^{-1}$ for six regions and below $7 \% \mathrm{yr}^{-1}$ for the six other regions.
GMDD

Calibration and evaluation of the

Nexus Land-Use model

F. Souty et al.

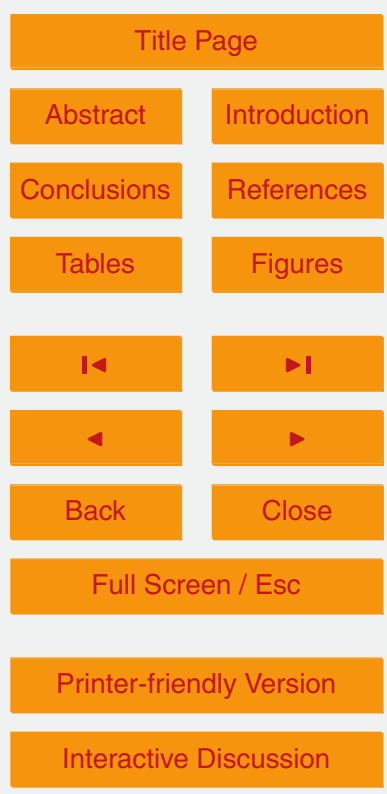


Globally, Nexus Land-Use overestimates cropland area in the 1960's (+7.5\%) and 1970 's (+10\%). This can be explained by the effect of public intervention and price stabilisation. During the last decades, the use of industrial fertilisers has been largely subsidised, directly or indirectly, in many regions of the world. These subsidies, as well 5 as interventions on commodity markets, contributed to stabilising farm revenues. In fertiliser price statistics, subsidies are deducted wherever possible. The fertiliser price provided by the World Bank therefore probably does not correspond to the price actually paid by farmers, introducing errors in our simulations over the past. Fertiliser subsidies have been progressively suppressed since the 80 's/90's. Therefore, we can expect these errors to be of less importance in future simulations. The sharp overestimation of cropland area in the 1970s in China can also be explained by inconsistencies between pasture area evolution from Ramankutty and Foley (1999) and the consumed grass yield of intensive pasture from Bouwman et al. (2005) which are based on different land-use datasets.

15 To assess the accuracy of the endogenously calculated intermediary consumption, it was compared to nitrogen fertiliser consumption from the FAO (2012) (Fig. 14). Overall, the model tends to underestimate the consumption of fertiliser, which is consistent with yield underestimation and cropland area overestimation.

Considering the large variability in trade, simulated net imports of food crops fits 20 rather well with the Agribiom data for most of the regions over 1980-2006 (Fig. 15). Except for India, Brazil and Europe the coefficient of variation of the RMSE on net imports of food crops is below $54 \%$ (Table 4). Concerning trade in ruminant products, performances of the model are lower. Net imports of ruminant and monogastric products are shown in Sect. C2.

To assess the impact of trade bias on cropland area bias, we compared results of the simulation presented here (called ET in the following for endogenous trade) with a retrospective simulation configured with trade forced (FT) using Agribiom data. Except for Canada and Europe, for which RMSE ${ }_{1961-2006}^{\text {cropland }}$ is respectively $12 \%$ and $45 \%$ higher in ET compared to FT, RMSE ${ }_{1961-2006}^{\text {cropland }}$ is lower with ET for other regions (up to $-63 \%$ in

\section{GMDD}

6, 6975-7046, 2013

Calibration and evaluation of the

Nexus Land-Use model

F. Souty et al.

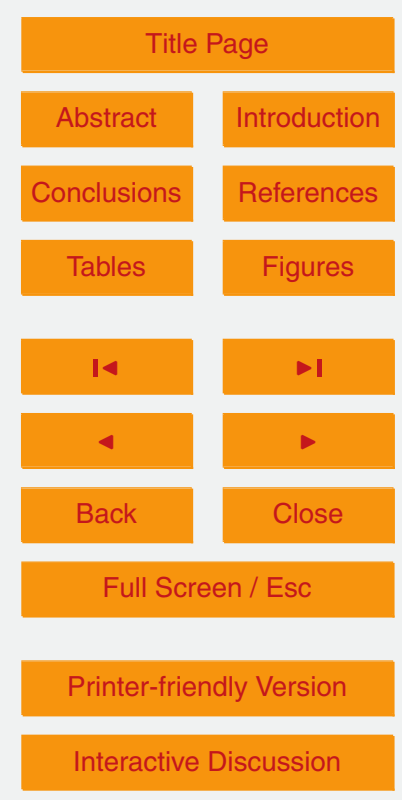


Brazil). This suggests that the model bias on trade compensates for yield bias in most regions. However, this effect is not sizeable at the world level, CV(RMSE) ${ }_{1961-2006}^{\text {cropland }}$ is $4.5 \% \mathrm{yr}^{-1}$ in $\mathrm{FT}$ and $3.9 \% \mathrm{yr}^{-1}$ in ET.

Figure 16 shows the world calorie price for the two retrospective simulations us5 ing either $p_{\chi}^{\mathrm{WB}}$ (default case) or $p_{\chi}^{\mathrm{FAO}}$. In Nexus Land-Use, the world calorie price is defined as the mean of the regional calorie price weighted by the share of each region in total exports. When comparing our calorie price with the food price index from the World Bank (2012a), it appears that the world calorie price is underestimated by Nexus Land-Use before 1985 , both with $p_{\chi}^{\mathrm{WB}}$ and $p_{\chi}^{\mathrm{FAO}}$. It is challenging to explain

\section{Sensitivity to input data}

Data on agriculture and land-use are surrounded by large uncertainties. According to Young, "data on land-use are among the least reliable of international statistics" due to unreported harvested areas, degraded croplands, underestimation of land occupied by settlement, uncultivated patches, footpaths and ditches (Young, 1999, 2000). "For example, the US data on croplands used by FAOSTAT includes idled cropland, which includes land under the Conservation Reserve Program that amounts to roughly $9 \%$ of the total cropland area, and is often idled for longer than $5 \mathrm{yr}$ (Lubowski et al., 2006)" (Ramankutty et al., 2008).

Land-use datasets and potential yield estimations vary greatly according to various 25 studies. As previously shown, this also concerns fertiliser price, which may dramatically decrease or not during the 1960 s according to the computing methodology followed.

Calibration and evaluation of the

Nexus Land-Use model

F. Souty et al.

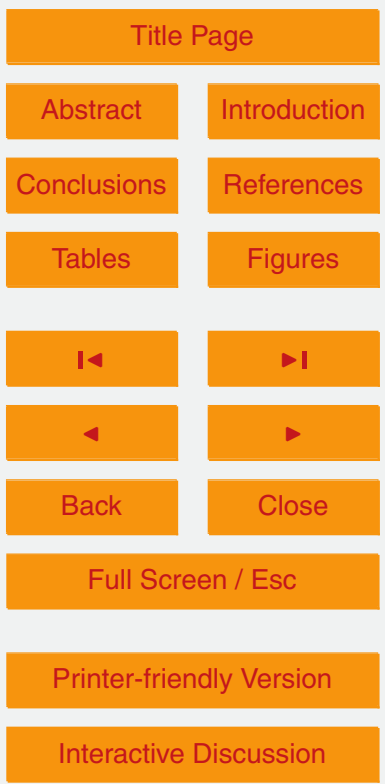


These discrepancies on input data may thus impact model error. To assess the effect of input data on model outputs, we run in this section a sensitivity analysis to the following input data:

- Two indexes of fertiliser price: $p_{\chi}^{\mathrm{WB}}$ from the World Bank (2012a) and $p_{\chi}^{\mathrm{FAO}}$ calculated from FAO data (see Sect. 3.2).

- Two land-use datasets: the original land-use dataset of Nexus Land-Use version 1.0 - comprising cropland and pasture maps from Ramankutty et al. (2008) and a forest map from Poulter et al. (2011) - and the land-use dataset from Erb et al. (2007).

- Two potential yields datasets: LPJmL and Licker et al. (2010) (see Appendix B).

Total cropland area according to Erb et al. (2007) is $1522 \mathrm{Mha}$, which is roughly equal to the Ramankutty et al. (2008) estimation (1495 Mha). However, the spatial distributions are quite different, with a mismatch of 400 Mha between the two datasets. Erb et al. (2007) reports 4685 Mha of pasture compared to 2711 Mha in Ramankutty et al. (2008). This discrepancy is explained by methodological differences. The Ramankutty et al. (2008) pasture distribution is explicitely estimated by combining agricultural inventory data with two satellite-derived products, while Erb et al. (2007) deduce pasture distribution by using a subtractive approach. The Ramankutty et al. (2008) pasture map is almost entirely included in the Erb et al. (2007) one. Forest area from Erb et al. (2007) is 3495 Mha compared to 5064 Mha in Poulter et al. (2011) and is almost completly included in it.

Potential yields from Licker et al. (2010) are calculated using a statistical approach based on actual regional data (while LPJmL uses a process-based approach), based on the global crop dataset from Monfreda et al. (2008) in conjunction with globally gridded climate datasets. The mean potential yield at the global scale from Licker et al. (2010) is $17 \%$ lower than in LPJmL. Spatial distributions of actual and potential yields as well as histograms of the land area classes of potential yield are displayed in Appendix $\mathrm{B}$.
6, 6975-7046, 2013

Calibration and evaluation of the

Nexus Land-Use

model

F. Souty et al.

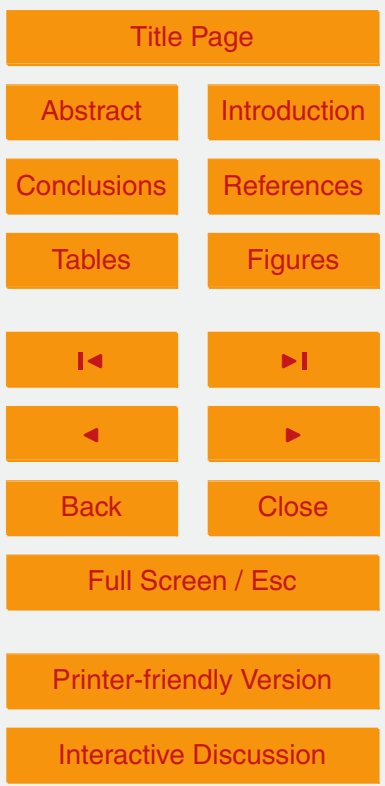

Interactive Discussion 
To ensure a consistent comparison between results, $R_{\max }^{\min }$ ratios have been recalibrated for each yield and land-use datasets (Table 6). Results of the sensitivity analysis are shown in Fig. 17. The overestimation of the cropland area in 1960 is significantly increased when using $p_{\chi}^{\mathrm{FAO}}(+18 \%$ against $+7.5 \%)$ as it yields much higher 5 values than $p_{\chi}^{\mathrm{WB}}$ during this preriod (Fig. 5). At the world level however, input data have little impact on model performance. CV(RMSE) ${ }_{1961-2006}^{\text {cropland }}$ range from $3.5 \% \mathrm{yr}^{-1}$ with Licker-Ramankutty/Poulter whatever the fertiliser price index used to $4.6 \% \mathrm{yr}^{-1}$ with LPJmL/Ramankutty/Poulter/ $p_{\chi}^{\mathrm{FAO}}$. At the regional level, the impact of input data on performance of the model can be significant, especially in the OECD Pacific, the Middle-East and Africa. This stresses the importance of testing the impact of input data on forecasting simulations. Finally, no dataset appears to perform better, hinting that the error is due to model structure rather than to input data.

\section{Concluding remarks}

This article allows us to understand the difficulties in modelling agricultural land-use changes at the level of large regions of the world. Since the 1960s, the agricultural sector of most countries has undergone profound structural changes. Despite the great complexity of the underlying cause triggering these structural changes, this study shows that the Nexus Land-Use model can reproduce part of the agricultural land-use changes.

20 In this evaluation several components have been assessed and the main results are: when forced by nitrogen fertiliser consumption, the crop production function is rather well suited to reproduce historical trends in crop yields in most regions. The crop production function cannot reproduce the specific patterns observed in the Former Soviet Union, the OECD Pacific or Europe. Performances of the trade module vary widely among regions but is correct considering the large variability of trade over 1961-2006. Overall, the Nexus Land-Use model reproduces trends in food prices, cropland and 7004
GMDD

Calibration and evaluation of the

Nexus Land-Use model

F. Souty et al.

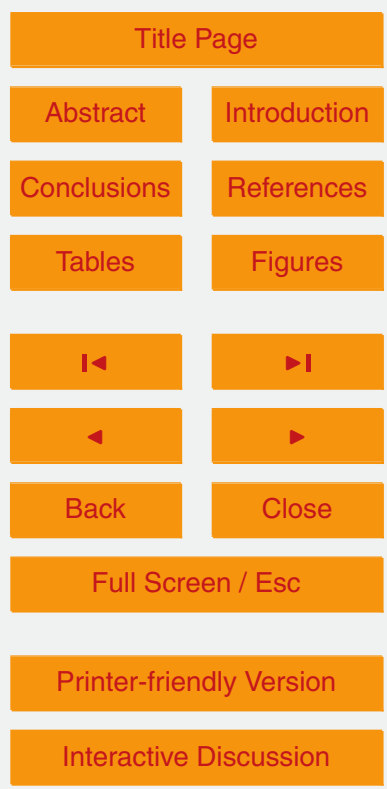


pasture areas from 1980 to 2006 but tends to underestimate food prices and overestimate cropland area in the 1960s, showing the limits of our model to mimic the whole complexity of the agricultural sector.

Finally, if this retrospective analysis gives many interesting insights into model func5 tioning, we cannot draw direct conclusions on its accuracy for prospective analysis. Actually, the agricural sector may be increasingly constrained by growing food and biomass energy demand in a context of slowdown of yield growth rates (Alston et al., 2009), changing the relevance of some mechanisms of Nexus Land-Use.

\section{Appendix A}

\section{Changes from Nexus Land-Use version 1.0}

\section{A1 Intensive pasture areas}

Intensive pasture areas of the old and the new Bouwman et al. (2005) dataset are shown in Table 5. Symmetric changes appear in residual pasture areas since they are defined as the difference between pastures from Ramankutty et al. (2008) located at

the right of the limit land class (high yield land classes) and intensive pasture areas from Bouwman et al. (Souty et al., 2012, p. 1308-09). In addition, consumed grass yields on intensive and extensive pastures are adjusted so that total grass consumed in each system and in each region remains unchanged.

\section{A2 Fodder crops in global supply/demand balance}

To account for fodder crop included in the LPJmL model (dynamic category), the demand for feed to produce ruminant products (Souty et al., 2012, Eq. 4) is now:
GMDD

$6,6975-7046,2013$

Calibration and evaluation of the

Nexus Land-Use

model

F. Souty et al

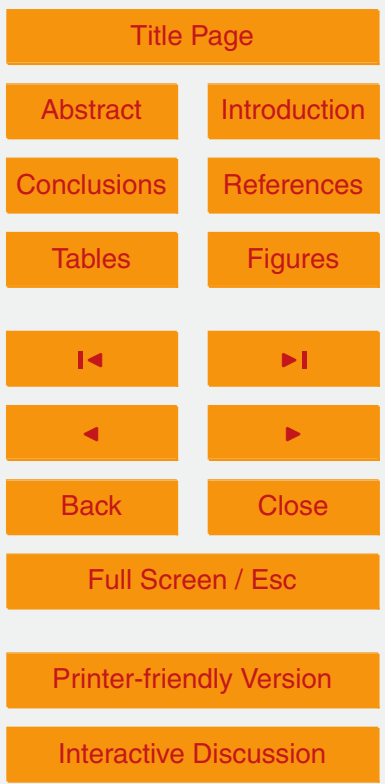


$D_{\mathrm{r}, \text { int }}^{\mathrm{fc}}=Q_{\mathrm{r}, \text { int }} \beta_{\mathrm{r}, \text { int }}\left(\phi_{\mathrm{r}, \text { int }}^{\mathrm{fc}}+\phi_{\mathrm{r}, \text { int }}^{\mathrm{fodder}} \frac{Q_{\text {fodder }}^{\mathrm{LPJmL}}(t=2001)}{D_{\mathrm{r}, \text { int }}^{\mathrm{fodder}}(t=2001)}\right)$

GMDD

$6,6975-7046,2013$

where, $Q_{\text {fodder }}^{\mathrm{LPJmL}}(t=2001)$ is the fodder crop production included in LPJmL at the base year in each region in Mkcal of grain equivalent from Monfreda et al. (2008) and $D_{\mathrm{r} \text {,int }}^{\text {fodder }}(t=2001)$ is the demand for residues and fodder for ruminant animals at the

5 base year. In this way, part of the demand for fodder crops is moved to the demand for food crop feeding ruminant animals $D_{\mathrm{r} \text {,int }}^{\mathrm{fc}}$. During the simulation, this part is a constant share of the demand for residues and fodder by ruminant animals. This is not needed when using the Licker et al. (2010) yield dataset which does not include fodder crops. Fodder crop production was converted into grain equivalents by using, for each fodder 10 crop in each region, the ratio between the mean yield of the corresponding grain crop (e.g. maize for fodder maize) and the fodder crop mean yield.

\section{A3 Actual and potential yields taking into account multicropping}

Actual and potential yields have been modified to take into account cropping systems with more than one crop a year (multicropping). In Nexus Land-Use version 1.0, actual 15 and potential yields ( $y_{\mathrm{CFT}, /}^{\text {actual }}$ and $y_{\mathrm{CFT}, \text {, }}^{\max }$, Souty et al., 2012, p. 1304-1305) were "harvest yield" (the amount of product gained per unit of area that is actually harvested and per harvest event) whereas fractional coverage per grid cell of each crop functional type $\left(f_{\mathrm{CFT}, l}\right.$, Souty et al., 2012, p. 1305) was equal to cultivated area and not to harvested area in the case of multicropping. As a result, for grid cells with multicropping, only one harvest was accounted for in the dynamic crop production category, other harvest(s) being accounted for in the other crops production category.

Calibration and evaluation of the

Nexus Land-Use model

F. Souty et al.

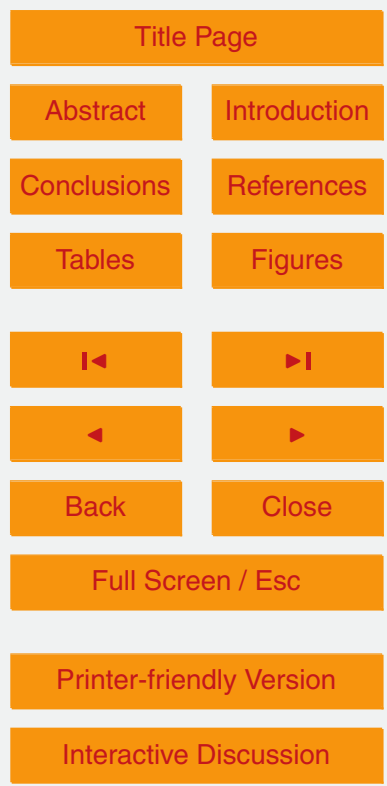


To take into account multicropping, the representative potential yield on grid point I is now given by (see Eq. 10, Souty et al., 2012, for the old definintion):

$y_{I}^{\text {max,agg }}=\frac{\sum_{\mathrm{CFT}} y_{\mathrm{CFT}, I}^{\max } \times f_{\mathrm{CFT}, I}^{\text {harvested }} \times \mathrm{cal}_{\mathrm{CFT}}}{\sum_{\mathrm{CFT}} f_{\mathrm{CFT}, I}}$

where $f_{\mathrm{CFT} /}^{\text {harvested }}$ are harvested area per crop functional type expressed as a fraction of 5 grid cell. The representative actual yield is computed likewise. Spatial distributions are displayed in Figs. 19 and 21. Histograms of cropping intensity in each region of the model are displayed in Fig. 18.

\section{Appendix B}

\section{Yield datasets}

10 Figures 19 to 22 show spatial distribution of actual and potential yields using LPJmL and Licker et al. (2010) datasets. Figures 23 and 24 show two histograms of the land area classes of potential yield using different land-use and potential yields datasets.

\section{Appendix C}

\section{Evaluation and calibration of specific model components}

\section{C1 Crop yield function in each land class}

$s_{\min }^{\text {ref }}$ is a world reference for the initial slope of the yield response to fertilisers. It could not be an average of regional $s_{\min k}$ because $\alpha_{1 C k}$ value depends on $R_{\max k}^{\min }$ (calibrated at the base year 2001, Souty et al., 2012, p. 1316). To get the value of $s_{\mathrm{min}}^{\text {ref }}$, we used a first

Calibration and evaluation of the

Nexus Land-Use

model

F. Souty et al.

Title Page

Abstract

Introduction

Conclusions

Tables

Figures

14

4

Back

Close

Full Screen / Esc

Printer-friendly Version

Interactive Discussion 
estimation of regional $R_{\max k}^{\min }$, called $R_{\max k}^{\min r e f}$, minimising the RMSE on the modelled dynamic cropland area over the 1961-2006 period. $s_{\min }^{\text {ref }}$ is then defined as the average of resulting $s_{\min k}^{\text {ref }}=\frac{P_{k}^{\text {NPK }}}{\alpha_{I C K}\left(R_{\max k}^{\min r e f}\right)}$ values weighted by the observed areas of dynamic crops in each region:

$5 \quad R_{\max k}^{\min \text { ref }}=\operatorname{argmin} \sqrt{\frac{1}{T} \sum_{t}\left(\operatorname{Sdyn}_{k, t}^{\text {model }}\left(R_{\max k}^{\min \text { ref }}\right)-\operatorname{Sdyn}_{k, t}^{\text {obs }}\right)^{2}}$

$S_{\min }^{\text {ref }}=\sum_{k} \frac{\sum_{t} \operatorname{Sdyn}_{k, t}^{\text {obs }}}{\sum_{I, t} \operatorname{Sdyn}_{l, t}^{\text {obs }}} S_{\min k}^{\text {ref }}\left(R_{\max k}^{\min r e f}\right)=\sum_{k} \frac{\sum_{t} \operatorname{Sdyn}_{k, t}^{\text {obs }}}{\sum_{I, t} \operatorname{Sdyn}_{l, t}^{\text {obs }}} \frac{P_{k}^{\mathrm{NPK}}}{\alpha_{\mathrm{IC} k}\left(R_{\max k}^{\min r e f}\right)}$

\section{C2 International trade module}

Root-mean-square errors on trade are calculated over the period 1980-2006 considering that international trade was too limited before 1980. The sensitivity analysis is done with 4 values for $\alpha_{k}^{\mathrm{fc}, \mathrm{imp}}$ and $\alpha_{k}^{\mathrm{r} \text {,imp }}$ evolution rates from 1 to $4 \%$ per year, 8 values for $\gamma_{\mathrm{fc}}$ from 0.5 to 4 and 4 values for $\gamma_{\mathrm{r}}$ from 0.5 to 2 . Results shown on the figures concerning trade of food crops come from simulations using calibrated values for ruminant trade parameters $\left(\alpha_{k}^{\text {r,imp }}\right.$ evolution rate $=2 \% \mathrm{yr}^{-1}$ and $\left.\gamma^{r}=0.5\right)$ and conversely

15 for figures concerning trade in ruminant products $\left(\alpha_{k}^{\mathrm{fc}, \mathrm{imp}}\right.$ evolution rate $=3 \% \mathrm{yr}^{-1}$ and $\gamma^{\mathrm{fc}}=1$ ). The impact of food crop trade parameters on ruminant product trade is negligible and vice versa. Figure 25 shows global errors on imports and exports of food crops and ruminant products. Figures 26 and 27 show net imports of ruminant and monogastric products as simulated by Nexus Land-Use compared to Agribiom data.

Calibration and evaluation of the

Nexus Land-Use

model

F. Souty et al.

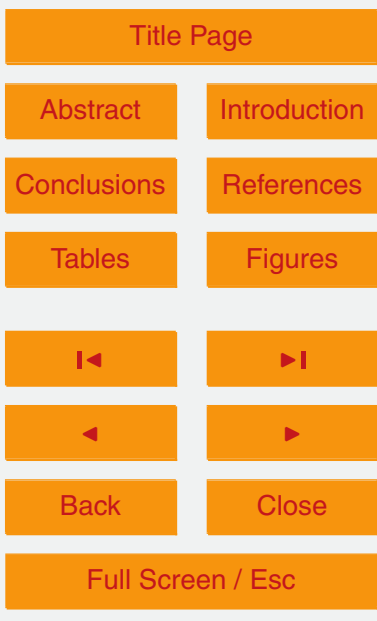

Printer-friendly Version

Interactive Discussion 
Acknowledgements. We gratefully acknowledge financial support from the GIS Climat Environnement Société ACACCYA project. Authors thanks Alberte Bondeau, Lex Bouwman and Rachel Licker for providing data. Nicolas Viovy for the ORCHIDEE simulation and Aude Valade for her help on English language.

5

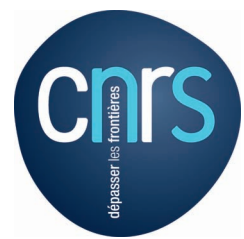

The publication of this article is financed by CNRS-INSU.

\section{References}

Acharya, S.: Fertilizer Subsidy in Indian Agriculture: Some Issues, French Research Institutes in India, Chap. 3, p. 334, available at: http://www.centre-cired.fr/IMG/pdf/DORIN_JULLIEN_ 2004_-_Agricultural_incentives_in_India_presentation_.pdf, 2004. 7024

Alston, J. M., Beddow, J. M., and Pardey, P. G.: Agricultural research, productivity, and food prices in the long run, Science, 325, 1209-1210, 2009. 7005

Beckman, J., Hertel, T. W., and Tyner, W.: Validating energy-oriented CGE models, Energ. Econ., 33, 799-806, 2011. 6977

Bondeau, A., Smith, P. C., Saehle, S., Schaphoff, S., Lucht, W., Cramer, W., Gerten, D., LotzeCampen, H., Müller, C., Reichstein, M., and Smith, B.: Modelling the role of agriculture for the 20th century global terrestrial carbon balance, Glob. Change Biol., 13, 679-706, doi:10.1111/j.1365-2486.2006.01305.x, 2007. 6979

Bouwman, A., der Hoek, K. V., Eickhout, B., and Soenario, I.: Exploring changes in world ruminant production systems, Agr. Syst., 84, 121-153, doi:10.1016/j.agsy.2004.05.006, 2005. 6980, 6981, 6983, 6991, 6999, 7001, 7005, 7018

BP: British Petroleum: Statistical review of world energy, available at: www.bp.com/ statisticalreview (last access: 3 October 2012), 2012.
GMDD

6, 6975-7046, 2013

Calibration and

evaluation of the

Nexus Land-Use

model

F. Souty et al.

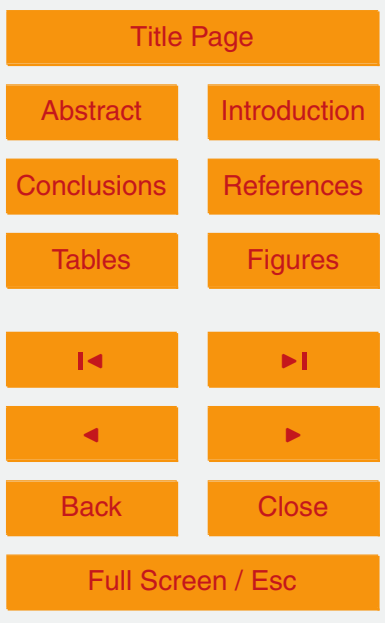

Printer-friendly Version

Interactive Discussion 
Cassman, K. G.: Ecological intensification of cereal production systems: yield potential, soil quality, and precision agriculture, P. Natl. Acad. Sci. USA, 96, 5952-5959, doi:10.1073/pnas.96.11.5952, 1999. 6990

Collatz, G. J., Berry, J. A., and Clark, J. S.: Effects of climate and atmospheric $\mathrm{CO}_{2}$ partial pressure on the global distribution of $\mathrm{C} 4$ grasses: present, past, and future, Oecologia, 114, 441-454, doi:10.1007/s004420050468, 1998. 6999

Dorin, B.: Agribiom Caloric Balance Sheets, updated estimates from Paillard et al., 2011, 2565, 2011. 6983, 6986, 6996, 7000, 7014, 7021

Erb, K.-H., Gaube, V., Krausmann, F., Plutzar, C., Bondeau, A., and Haberl, H.: A comprehensive global $5 \mathrm{~min}$ resolution land-use data set for the year 2000 consistent with national census data, J. Land Use Sci., 2, 191-224, doi:10.1080/17474230701622981, 2007. 7003, 7019,7043

Erb, K.-H., Haberl, H., Krausmann, F., Lauk, C., Plutzar, C., Steinberger, J. K., Müller, C., Bondeau, A., Waha, K., and Pollack, G.: Eating the Planet: feeding and fuelling the world sustainably, fairly and humanely, a scoping study, Tech. rep., Institute of Social Ecology, IFF - Faculty for Interdisciplinary Studies (Klagenfurt, Graz, Vienna) Klagenfurt University, Vienna, available at: http://www.uni-klu.ac.at/socec/downloads/WP116_WEB.pdf (last access: 16 December 2013), 2009. 6993

Evenson, R. E. and Gollin, D.: Assessing the impact of the green revolution, 1960 to 2000, Science, 300, 758-762, doi:10.1126/science.1078710, 2003. 6990

Fader, M., Rost, S., Müller, C., Bondeau, A., and Gerten, D.: Virtual water content of temperate cereals and maize: present and potential future patterns, J. Hydrol., 384, 218-231, doi:10.1016/j.jhydrol.2009.12.011, 2010. 6990

FAO: Food and Agriculture Organisation of the United Nations: Statistical Database, available at: http://faostat.fao.org/ (last access: 15 October 2012), 2012. 6982, 6983, 6984, 6986, 6987, 6995, 7000, 7001, 7022, 7023, 7027, 7029, 7033

GTAP: Global Trade, Assistance, and Production: The GTAP 6 Data Base, Tech. rep., Center for Global Trade Analysis, Purdue University, 2006. 6982, 6983, 6989

Havlík, P., Schneider, U. A., Schmid, E., Böttcher, H., Fritz, S., Skalský, R., Aoki, K., Cara, S. D., Kindermann, G., Kraxner, F., Leduc, S., McCallum, I., Mosnier, A., Sauer, T., and Obersteiner, M.: Global land-use implications of first and second generation biofuel targets, Energ. Policy, 39, 5690-5702, doi:10.1016/j.enpol.2010.03.030, 2011. 6979

Calibration and evaluation of the

Nexus Land-Use

model

F. Souty et al

Title Page

Abstract Introduction

Conclusions

Tables

References

Figures

14

4

Back

Full Screen / Esc

Printer-friendly Version

Interactive Discussion 
Hay, R. K. M.: Harvest index: a review of its use in plant breeding and crop physiology, Ann. Appl. Biol., 126, 197-216, doi:10.1111/j.1744-7348.1995.tb05015.x, 1995. 6990

Hertel, T. W. and Tsigas, M. E.: Tax policy and US agriculture: a general equilibrium analysis, Am. J. Agr. Econ., 70, 289-302, doi:10.2307/1242069, 1988. 6998

5 Krinner, G., Viovy, N., de Noblet-Ducoudré, N., Ogée, J., Polcher, J., Friedlingstein, P., Ciais, P., Sitch, S., and Prentice, I. C.: A dynamic global vegetation model for studies of the coupled atmosphere-biosphere system, Global Biogeochem. Cy., 19, GB1015, doi:10.1029/2003GB002199, 2005. 6999

Ladha, J. K., Pathak, H., Krupnik, T. J., Six, J., and van Kessel, C.: Efficiency of fertilizer nitrogen in cereal production: retrospects and prospects, Adv. Agron., 87, 85-156, doi:10.1016/S0065-2113(05)87003-8, 2005. 6994

Licker, R., Johnston, M., Foley, J. A., Barford, C., Kucharik, C. J., Monfreda, C., and Ramankutty, N.: Mind the gap: how do climate and agricultural management explain the "yield gap" of croplands around the world?, Global. Ecol. Biogeogr., 19, 769-782, doi:10.1111/j.1466-8238.2010.00563.x, 2010. 7003, 7006, 7007, 7019, 7039, 7041, 7043

Lotze-Campen, H., Müller, C., Bondeau, A., Rost, S., Popp, A., and Lucht, W.: Global food demand, productivity growth, and the scarcity of land and water resources: a spatially explicit mathematical programming approach, Agr. Econ., 39, 325-338, 2008. 6977, 6979

Lubowski, R. N., Vesterby, M., Bucholtz, S., Baez, A., and Roberts, M. J.: Major Land Uses in the United States, 2002, Tech. rep., United States Department of Agriculture, available at: http://www.ers.usda.gov/publications/eib-economic-information-bulletin/eib14.aspx (last access: 16 December 2013), 2006. 7002

Monfreda, C., Ramankutty, N., and Foley, J. A.: Farming the planet: 2. Geographic distribution of crop areas, yields, physiological types, and net primary production in the year 2000 , Global Biogeochem. Cy., 22, GB1003, doi:10.1029/2007GB002947, 2008. 6986, 6987, 6988, 7003, 7006

Nicolella, A. C., Dragone, D. S., and Bacha, C. J. C.: Determinantes da demanda de fertilizantes no Brasil no período de 1970 a 2002, Revista de Economia e Sociologia Rural, 43, 81-100, 2005.

so Poulter, B., Ciais, P., Hodson, E., Lischke, H., Maignan, F., Plummer, S., and Zimmermann, N. E.: Plant functional type mapping for earth system models, Geosci. Model Dev., 4, 993-1010, doi:10.5194/gmd-4-993-2011, 2011. 7003, 7019, 7042 
Ramankutty, N. and Foley, J. A.: Estimating historical changes in global land cover: croplands from 1700 to 1992, Global Biogeochem. Cy., 13, 997-1027, 1999. 6982, 6983, 6987, 6988, 6989, 7000, 7001, 7032

Ramankutty, N., Evan, A. T., Monfreda, C., and Foley, J. A.: Farming the planet: 1. Geo5 graphic distribution of global agricultural lands in the year 2000, Global Biogeochem. Cy., 22, GB1003, doi:10.1029/2007GB002952, 2008. 6986, 6999, 7002, 7003, 7005, 7019, 7042

Ravn, M. O. and Uhlig, H.: On adjusting the Hodrick-Prescott filter for the frequency of observations, Rev. Econ. Stat., 84, 371-376, doi:10.1162/003465302317411604, 2002. 6985, 6987,6990

10 Ricardo, D.: On the Principles of Political Economy and Taxation, John Murray, London, 1817. 6980

Ronneberger, K., Berrittella, M., Boselle, F., and Tol, R. S.: KLUM@GTAP: Spatially-Explicit, Biophysical Land Use in a Computable General Equilibrium Model, Gtap working papers, Center for Global Trade Analysis, Department of Agricultural Economics, Purdue University, available at: http://econpapers.repec.org/RePEc:gta:workpp:2611 (last access: 16 December 2013), 2008. 6977

Seufert, V., Ramankutty, N., and Foley, J. A.: Comparing the yields of organic and conventional agriculture, Nature, 485, 229-232, doi:10.1038/nature11069, 2012. 6993

Souty, F., Brunelle, T., Dumas, P., Dorin, B., Ciais, P., Crassous, R., Müller, C., and Bondeau, A.: The Nexus Land-Use model version 1.0, an approach articulating biophysical potentials and economic dynamics to model competition for land-use, Geosci. Model Dev., 5, 1297-1322, doi:10.5194/gmd-5-1297-2012, 2012. 6977, 6978, 6979, 6981, 6982, 6983, 6986, 6988, 6989, 6991, 6992, 6993, 6994, 6996, 6998, 6999, 7005, 7006, 7007

UNSD: United Nations Statistics Division: National Accounts Estimates of Main Aggregates, available at: http://data.un.org/ (last access: 26 October 2011), 2011. 6983, 6989

USDA: United States Department of Agriculture: Fertilizer price indexes, available at: http:// www.ers.usda.gov/data-products/fertilizer-use-and-price.aspx (last access: 25 May 2012), 2012. 7024

Van Groenigen, J. W., Velthof, G. L., Oenema, O., Van Groenigen, K. J., and Van Kessel, C.: Towards an agronomic assessment of $\mathrm{N}_{2} \mathrm{O}$ emissions: a case study for arable crops, Eur. J. Soil Sci., 61, 903-913, doi:10.1111/j.1365-2389.2009.01217.x, 2010. 6994
GMDD

6, 6975-7046, 2013

Calibration and

evaluation of the

Nexus Land-Use

model

F. Souty et al

Title Page

Abstract

Introduction

Conclusions

Tables

References

Figures

14

4

Back

Full Screen / Esc

Printer-friendly Version

Interactive Discussion 
World Bank: Commodity Markets Data, available at: http://go.worldbank.org/4ROCCIEQ50, 5 July 2012 update (last access: 26 September 2012), 2012a. 6983, 6985, 7000, 7002, 7003, 7024,7035

World Bank: Inflation, GDP deflator from World Bank national accounts data, and OECD Na5 tional Accounts data files, available at: http://data.worldbank.org/indicator/NY.GDP.DEFL.KD. ZG (last access: 20 September 2012), 2012b. 7024

Young, A.: Is there really spare land? A critique of estimates of available cultivable land in developing countries, Environ. Develop. Sustain., 1, 3-18, doi:10.1023/A:1010055012699, 1999. 7002

10 Young, A.: How much spare land exists?, Bull. Int. Un. Soil Sci., 97, 51-55, 2000. 7002

GMDD

6, 6975-7046, 2013

Calibration and

evaluation of the

Nexus Land-Use

model

F. Souty et al.

Title Page

Abstract

Introduction

Conclusions

References

Tables

Figures

14

4

Back

Printer-friendly Version

Interactive Discussion 
Table 1. Population in 1961 and 2006 from Agribiom (Dorin, 2011) in millions. OECD Pacific includes Australia, New Zealand, Japan and South Korea. FSU stands for Former Soviet Union and Rest of LAM for Rest of Latin America.

\begin{tabular}{lrr}
\hline Regions & 1961 & 2006 \\
\hline USA & 198 & 328 \\
Canada & 18 & 33 \\
Europe & 457 & 599 \\
OECD Pacific & 133 & 200 \\
FSU & 218 & 277 \\
China & 661 & 1328 \\
India & 457 & 1148 \\
Brazil & 75 & 188 \\
Middle East & 42 & 161 \\
Africa & 287 & 929 \\
Rest of Asia & 362 & 955 \\
Rest of LAM & 137 & 345 \\
\hline World & 3045 & 6491 \\
\hline
\end{tabular}

6, 6975-7046, 2013

Calibration and evaluation of the

Nexus Land-Use

model

F. Souty et al.

Title Page

Abstract Introduction

Conclusions References

Tables Figures

14

4

Back

Full Screen / Esc

Printer-friendly Version

Interactive Discussion 
Table 2. $R M S E_{1961-2006}^{\text {dyn. cropland }}$ in $\mathrm{Mhayr}^{-1}$ for calibrated minimum to potential yield ratio, followed by $\mathrm{CV}(\mathrm{RMSE})_{1961-2006}^{\text {dyn. cropland }}$ in brackets. Calibrated minimum to potential yield ratio $\left(R_{\max k}^{\min }\right.$ in percent), total consumption of fertiliser at the base year 2001 calculated using FAO data in Sect. $3.2\left(\mathrm{IC}_{\chi}^{\mathrm{FAO}}\right.$ in millions dollars), initial slope of the intermediary consumption function ( $\alpha_{\mathrm{IC} k}$ in $\left.\$ \mathrm{Mkcal}^{-1}\right)$, mean NPK price over the period 1999-2003 $\left(P^{\mathrm{NPK}}\right.$ in $\left.\$(\mathrm{kgNPK})^{-1}\right)$, initial slope of the crop production function in volume of fertiliser $\left(\frac{P_{k}^{\mathrm{NPK}}}{\alpha_{I C k}}\right.$ in Mkcal $\left.(\mathrm{kgNPK})^{-1}\right)$. World $\alpha_{\mathrm{IC}}$ is calculated by calibrating the crop production function on the whole world instead of calibrating it on each region. This value is not used in the model.

\begin{tabular}{lrrrrrrr}
\hline Regions & $\mathrm{RMSE}_{1961-2006}^{\text {dyn. cropland }}$ & $R_{\max k}^{\min }$ & \multicolumn{1}{c}{$\mathrm{IC}_{\chi}^{\mathrm{FAO}}$} & $\alpha_{\mathrm{IC} k}$ & $P^{\mathrm{NPK}}$ & $P^{\mathrm{NPK}} / \alpha_{\mathrm{IC} k}$ \\
\hline USA & 9.3 & $(11 \%)$ & 35 & 2505 & 1.2 & 154 & 132 \\
Canada & 2.1 & $(10 \%)$ & 30 & 451 & 2.4 & 274 & 116 \\
Europe & 12.2 & $(14 \%)$ & 20 & 4744 & 2.4 & 304 & 127 \\
OECD Pacific & 6.6 & $(43 \%)$ & 10 & 848 & 4.1 & 281 & 68 \\
FSU & 25.3 & $(23 \%)$ & 25 & 432 & 1.4 & 177 & 130 \\
China & 9.4 & $(11 \%)$ & 20 & 4847 & 1.3 & 162 & 124 \\
India & 14.3 & $(13 \%)$ & 15 & 3372 & 2.3 & 278 & 123 \\
Brazil & 4.2 & $(18 \%)$ & 25 & 978 & 1.9 & 225 & 116 \\
Middle-East & 4.4 & $(37 \%)$ & 10 & 557 & 4.5 & 270 & 60 \\
Africa & 5.1 & $(7 \%)$ & 15 & 584 & 2.0 & 252 & 128 \\
Rest of Asia & 4.5 & $(9 \%)$ & 30 & 2958 & 2.3 & 277 & 118 \\
Rest of LAM & 5.2 & $(15 \%)$ & 25 & 906 & 2.1 & 259 & 121 \\
\hline World & & - & - & 23182 & 1.8 & 232 & 127 \\
\hline
\end{tabular}

Calibration and

evaluation of the

Nexus Land-Use

model

F. Souty et al.

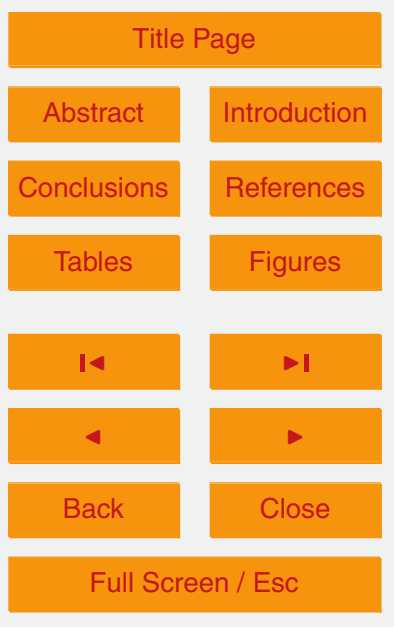

Printer-friendly Version

Interactive Discussion 
Table 3. Root-mean-square error on cropland area estimation over 1980-2006 and 1961-2006 in $\mathrm{Mhayr}^{-1}$, followed by RMSE as a percentage of the regional mean of observed cropland area during the period in brackets (CV(RMSE) ${ }_{1980-2006}^{\text {cropland }}$ and CV(RMSE $)_{1961-2006}^{\text {cropland }}$ in $\% \mathrm{yr}^{-1}$ ).

\begin{tabular}{lrrrr}
\hline Regions & \multicolumn{2}{c}{ RMSE $_{1980-2006}$ cropland } & \multicolumn{2}{r}{ RMSE $_{1961-2006}^{\text {cropland }}$} \\
\hline USA & 5 & $(3 \%)$ & 13 & $(7 \%)$ \\
Canada & 5 & $(11 \%)$ & 5 & $(12 \%)$ \\
Europe & 8 & $(5 \%)$ & 10 & $(6 \%)$ \\
OECD Pacific & 3 & $(11 \%)$ & 7 & $(23 \%)$ \\
FSU & 12 & $(5 \%)$ & 24 & $(11 \%)$ \\
China & 14 & $(10 \%)$ & 37 & $(25 \%)$ \\
India & 2 & $(1 \%)$ & 5 & $(3 \%)$ \\
Brazil & 3 & $(5 \%)$ & 3 & $(7 \%)$ \\
Middle-East & 2 & $(5 \%)$ & 6 & $(23 \%)$ \\
Africa & 26 & $(13 \%)$ & 28 & $(15 \%)$ \\
Rest of Asia & 4 & $(2 \%)$ & 6 & $(5 \%)$ \\
Rest of LAM & 3 & $(3 \%)$ & 5 & $(5 \%)$ \\
\hline World & 34 & $(2 \%)$ & 57 & $(4 \%)$ \\
\hline
\end{tabular}


Table 4. Root-mean-square error on net trade for food crops and ruminant products on the 1980-2006 period in $\mathrm{Tkcalyr}^{-1}$, followed by corresponding CV(RMSE).

\begin{tabular}{lrrrr}
\hline & \multicolumn{3}{c}{ Food crops } & \multicolumn{2}{c}{$\begin{array}{l}\text { Ruminant } \\
\text { products }\end{array}$} \\
\hline USA & 57 & $(15 \%)$ & 2 & $(17 \%)$ \\
Canada & 22 & $(26 \%)$ & 1 & $(42 \%)$ \\
Europe & 117 & $(75 \%)$ & 9 & $(126 \%)$ \\
OECD Pacific & 15 & $(11 \%)$ & 3 & $(27 \%)$ \\
FSU & 25 & $(27 \%)$ & 7 & $(264 \%)$ \\
China & 43 & $(49 \%)$ & 3 & $(56 \%)$ \\
India & 12 & $(116 \%)$ & 1 & $(134 \%)$ \\
Brazil & 91 & $(118 \%)$ & 1 & $(132 \%)$ \\
Middle-East & 11 & $(11 \%)$ & 2 & $(59 \%)$ \\
Africa & 17 & $(12 \%)$ & 3 & $(38 \%)$ \\
Rest of Asia & 47 & $(54 \%)$ & 2 & $(44 \%)$ \\
Rest of LAM & 32 & $(50 \%)$ & 3 & $(40 \%)$ \\
\hline World & 179 & \multicolumn{3}{c}{13} \\
\hline
\end{tabular}

$6,6975-7046,2013$

Calibration and evaluation of the

Nexus Land-Use model

F. Souty et al.

Title Page

Abstract Introduction

Conclusions References

Tables Figures

14 $\rightarrow 1$

4

Back

Close

Full Screen / Esc

Printer-friendly Version

Interactive Discussion 
Table 5. Intensive pasture areas for each region at the base year 2001 in Mha from Bouwman et al. (2005). Old data used in Nexus Land-Use version 1.0 and new data used in this paper.

\begin{tabular}{lrr}
\hline \multirow{2}{*}{ Regions } & \multicolumn{2}{c}{ Intensive } \\
& \multicolumn{2}{c}{ pasture area } \\
\cline { 2 - 3 } & Old & New \\
\hline USA & 121 & $64(-47 \%)$ \\
Canada & 5 & $10(+107 \%)$ \\
Europe & 84 & $84(+0 \%)$ \\
OECD Pacific & 24 & $24(+0 \%)$ \\
FSU & 48 & $46(-6 \%)$ \\
China & 74 & $81(+10 \%)$ \\
India & 4 & $5(+13 \%)$ \\
Brazil & 25 & $79(+213 \%)$ \\
Middle East & 7 & $9(+32 \%)$ \\
Africa & 64 & $65(+2 \%)$ \\
Rest of Asia & 12 & $13(+7 \%)$ \\
Rest of LAM & 43 & $42(-3 \%)$ \\
\hline World & 512 & $522(+2 \%)$ \\
\hline
\end{tabular}

\section{GMDD}

6, 6975-7046, 2013

Calibration and evaluation of the

Nexus Land-Use

model

F. Souty et al.

Title Page

Abstract Introduction

Conclusions References

Tables Figures

14

4

Back

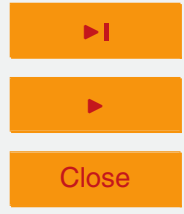

Full Screen / Esc

Printer-friendly Version

Interactive Discussion 
Table 6. Calibrated $\rho_{j}^{\min } / \rho_{i}^{\max }$ ratios using LPJmL or Licker et al. (2010) potential yield datasets and land-use datasets of Ramankutty et al. (2008) (for croplands and pastures) and Poulter et al. (2011) (for forests) or Erb et al. (2007).

\begin{tabular}{lccccc}
\hline Regions & \multicolumn{2}{c}{ LPJmL } & & \multicolumn{2}{c}{ Licker } \\
\cline { 2 - 3 } \cline { 5 - 6 } & Ramankutty/Poulter & Erb & & Ramankutty/Poulter & Erb \\
\hline USA & 35 & 40 & & 40 & 40 \\
Canada & 30 & 30 & & 30 & 30 \\
Europe & 20 & 20 & & 20 & 20 \\
OECD Pacific & 10 & 10 & & 10 & 10 \\
FSU & 25 & 25 & & 20 & 20 \\
China & 20 & 20 & & 15 & 15 \\
India & 15 & 15 & & 20 & 20 \\
Brazil & 25 & 20 & & 35 & 35 \\
Middle-East & 10 & 10 & & 10 & 10 \\
Africa & 15 & 15 & & 25 & 25 \\
Rest of Asia & 30 & 30 & & 25 & 25 \\
Rest of LAM & 25 & 25 & & 30 & 35 \\
\hline
\end{tabular}




Historical data for forcing
\begin{tabular}{|c|}
\hline $\begin{array}{c}\text { Historical gridded changes in cropland } \\
\text { and pastures (Ramankutty et al., 1999) }\end{array}$ \\
\hline \hline $\begin{array}{c}\text { Resource-use balances in calories and } \\
\text { pepulation from Agribiom (Dorin, 2011) }\end{array}$ \\
\hline $\begin{array}{c}\text { Fertiliser consumption and trade, } \\
\text { harvested area of food crops (FAO, 2010) }\end{array}$ \\
\hline \hline $\begin{array}{c}\text { Fertiliser price index, food price index } \\
\text { and deflators (World Bank, 2012a) }\end{array}$ \\
\hline $\begin{array}{c}\text { Changes in the added value of the } \\
\text { agricultural sector (UNSD, 2011) }\end{array}$ \\
\hline \hline $\begin{array}{c}\text { Share of the land rent in the added value } \\
\text { of the agricultural sector (GTAP, 2006) }\end{array}$ \\
\hline \hline $\begin{array}{c}\text { Irrigated and rainfed potential yields } \\
\text { from LPJmL (Bondeau et al., 2007) }\end{array}$ \\
\hline \hline Irrigated area (Fader et al., 2010) \\
\hline \hline $\begin{array}{c}\text { Feed requirement for animal production } \\
\text { (Bouwman et al., 2005) }\end{array}$ \\
\hline
\end{tabular}

Forced variables

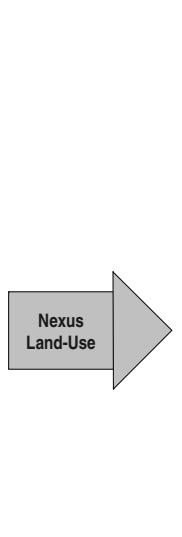

Evaluated outputs

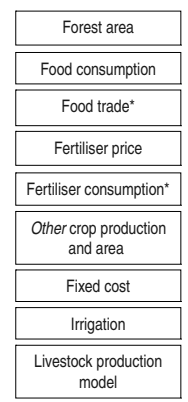
1961-2006

Source of data for evaluation
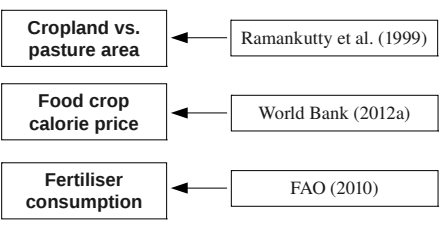

Food trade 4 Agribiom (Dorin, 2011)

Grass yield $1 \begin{gathered}\text { ORCHIDEE } \\ \text { (Krinner et al., 2005) }\end{gathered}$
Fig. 1. Description of the evaluation of the Nexus Land-Use model in this study. In the simulations, food trade and fertiliser consumption can be either forced or endogenously calculated.

\section{GMDD}

$6,6975-7046,2013$

Calibration and evaluation of the

Nexus Land-Use model

F. Souty et al.

\section{Title Page}

Abstract Introduction

Conclusions

References

Tables

Figures

14

4

Back

Printer-friendly Version

Interactive Discussion 


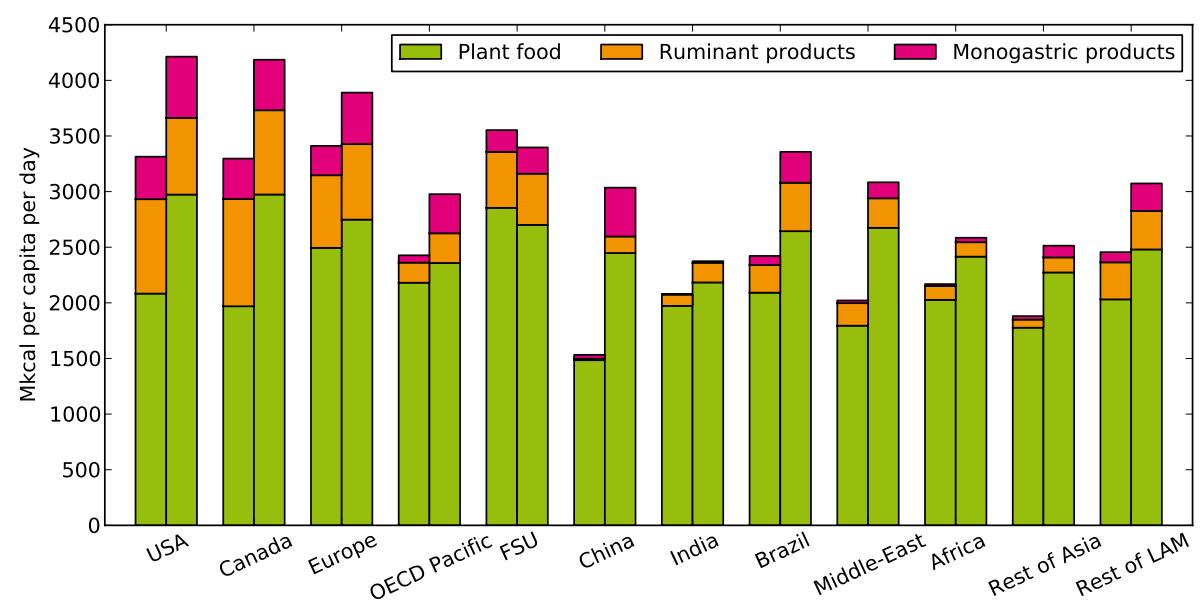

Fig. 2. Diets in 1961 (left hand bars) and in 2006 (right hand bars) from Agibiom (Dorin, 2011).

\section{GMDD}

$6,6975-7046,2013$

Calibration and evaluation of the

Nexus Land-Use model

F. Souty et al.

Title Page

\section{Abstract}

Conclusions

Tables

14

4

Back
Introduction

References

Figures

$\rightarrow 1$

Close

\section{Full Screen / Esc}

Printer-friendly Version

Interactive Discussion 


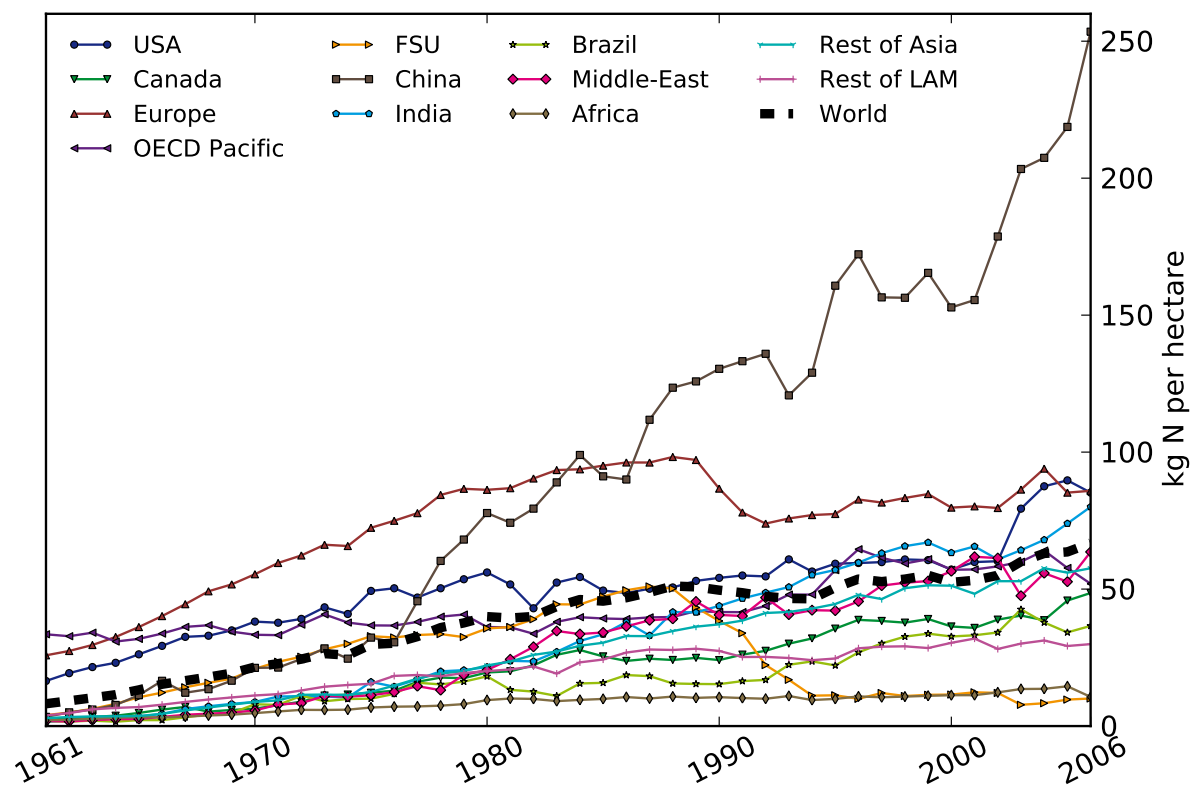

Fig. 3. Consumption of nitrogen fertilisers per hectare of cropland (FAO, 2012).

\section{GMDD}

6, 6975-7046, 2013

Calibration and evaluation of the

Nexus Land-Use model

F. Souty et al.

\section{Title Page}

Abstract

Introduction

Conclusions

References

Tables

Figures

14

Back

Close

Full Screen / Esc

Printer-friendly Version

Interactive Discussion 


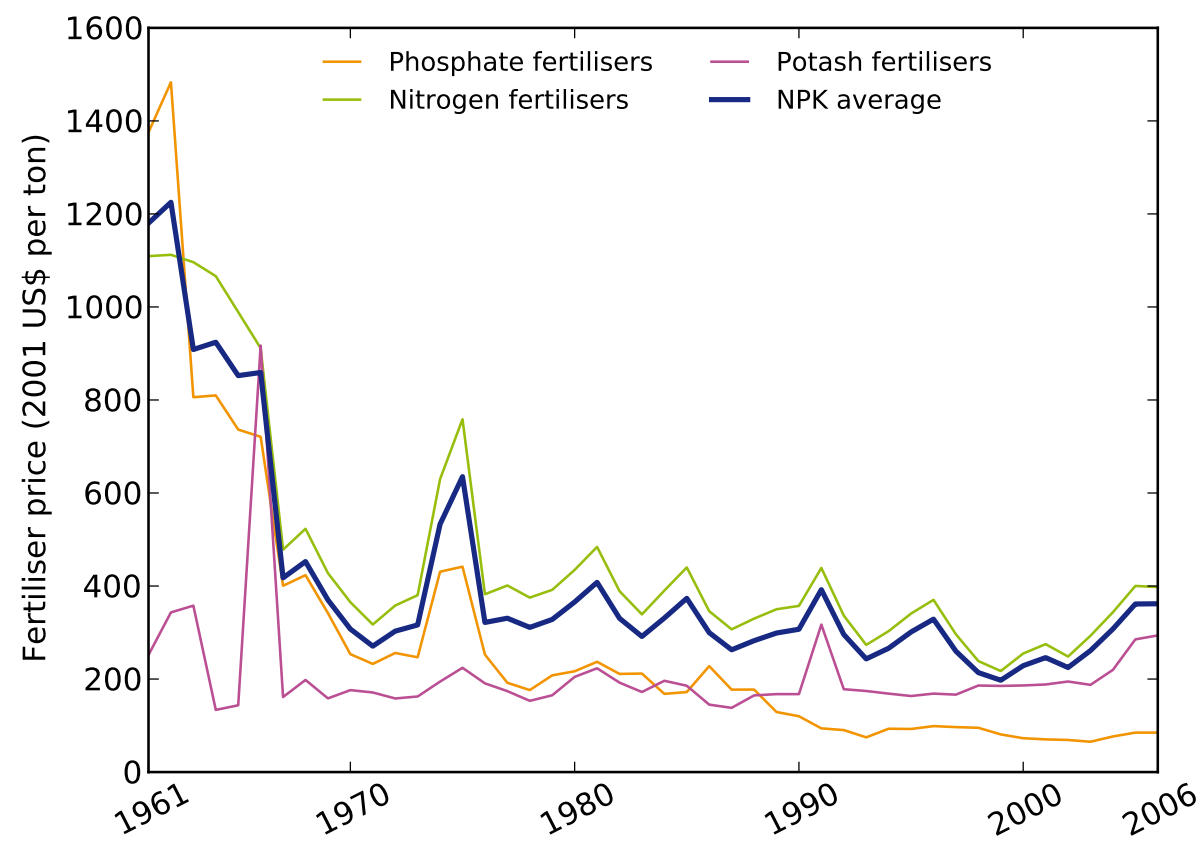

GMDD

6, 6975-7046, 2013

Calibration and evaluation of the

Nexus Land-Use model

F. Souty et al.

\section{Title Page}

Abstract

Introduction

Conclusions

References

Tables

Figures

14

$\rightarrow 1$

4

Back

Close

Full Screen / Esc

Printer-friendly Version

Interactive Discussion 


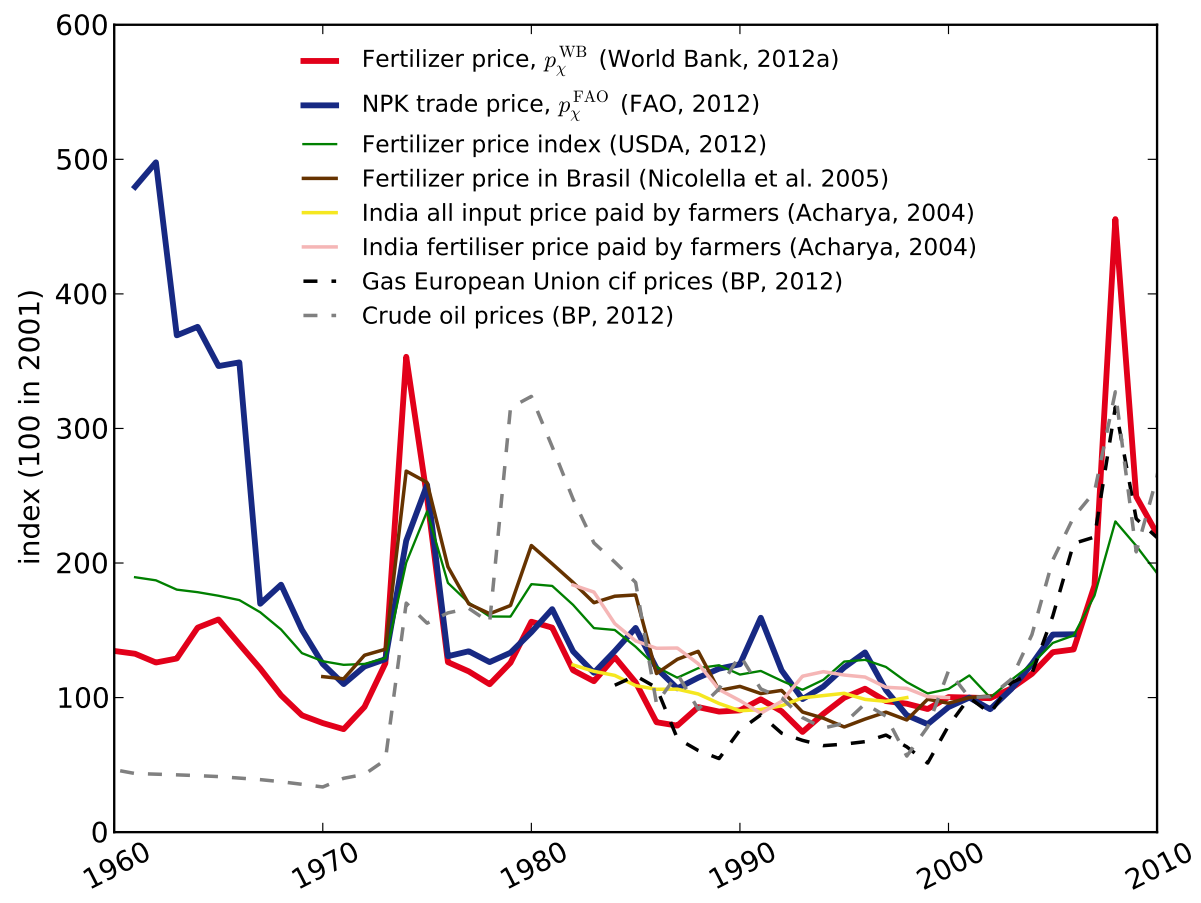

Fig. 5. Comparison of the fertiliser price index used in this study, from World Bank (2012a) price index data $\left(p_{\chi}^{\mathrm{WB}}\right)$ and the calculated world NPK trade price derived from FAO data $\left(p_{\chi}^{\mathrm{FAO}}\right.$, see Fig. 4) with other proxy data and regional data sources. USDA (2012) and Acharya (2004) are deflated using World Bank (2012b).

\section{GMDD}

$6,6975-7046,2013$

Calibration and evaluation of the

Nexus Land-Use

model

F. Souty et al.

Title Page

Abstract

Introduction

Conclusions

References

Tables

Figures

14

4

Back

Close

Printer-friendly Version

Interactive Discussion 

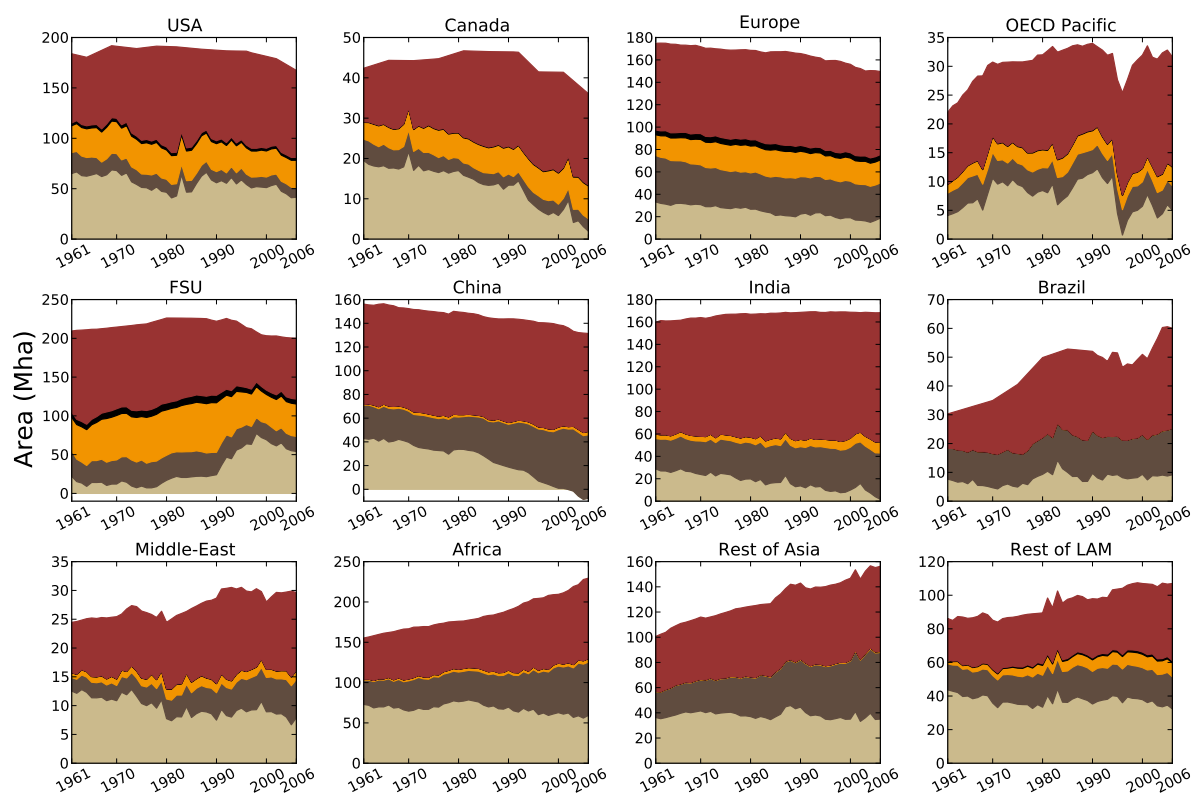

Dynamic food crops

Dynamic fodder crops $\quad$ Other fodder crops $\quad$ Other crops (non fodder) Remainder

Fig. 6. Decomposition of other cropland area and dynamic cropland area.

\section{GMDD}

6, 6975-7046, 2013

Calibration and evaluation of the

Nexus Land-Use model

\section{F. Souty et al.}

\section{Title Page}

Abstract Introduction

Conclusions

References

Tables

Figures

14

$>$ I

4

Back

Close

\section{Full Screen / Esc}

Printer-friendly Version

Interactive Discussion 


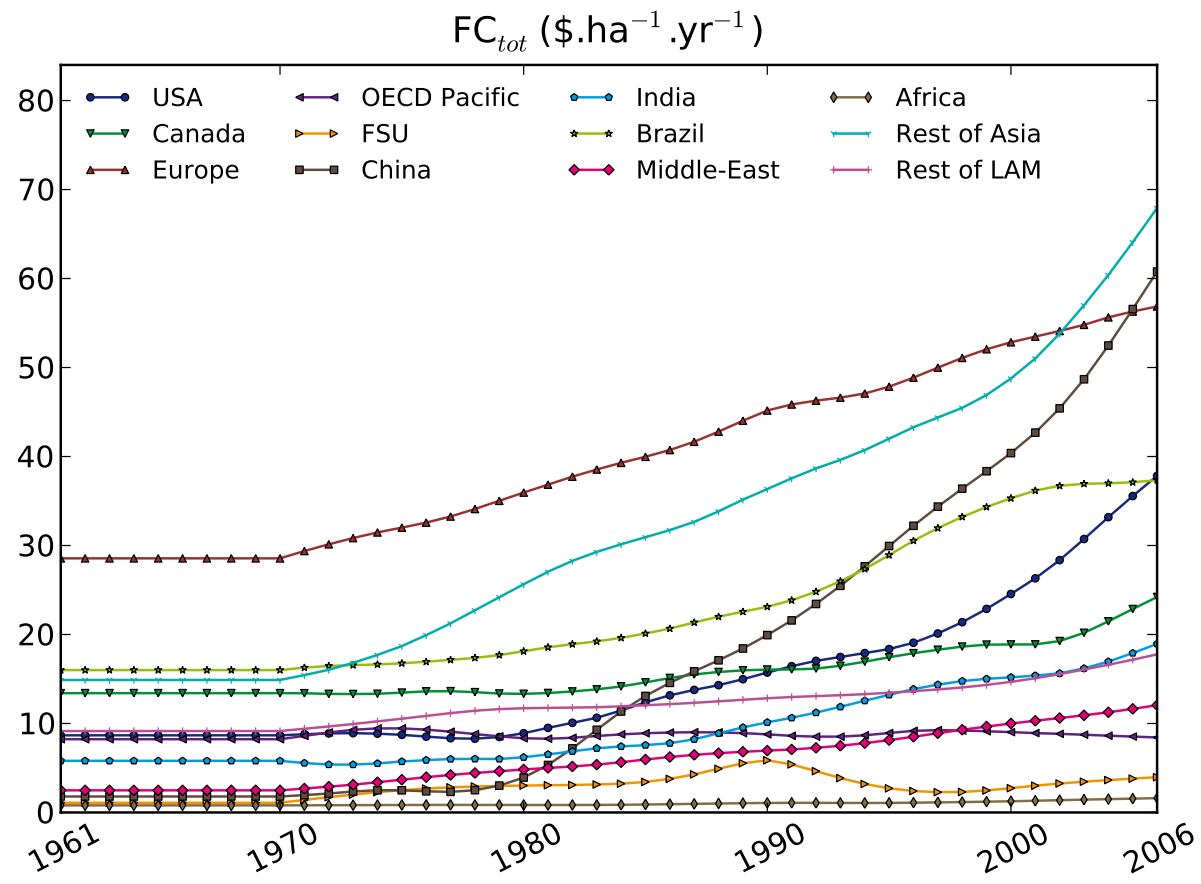

Fig. 7. Regional changes in $\mathrm{FC}_{\text {tot }}$ calculated by applying labour and capital indexes to calibrated values of $\mathrm{FC}_{\text {tot }}$.

\section{GMDD}

$6,6975-7046,2013$

Calibration and evaluation of the

Nexus Land-Use model

F. Souty et al.

\section{Title Page}

Abstract

Introduction

Conclusions

References

Tables

Figures

14

$\rightarrow 1$

4

Back

Close

Full Screen / Esc

Printer-friendly Version

Interactive Discussion 


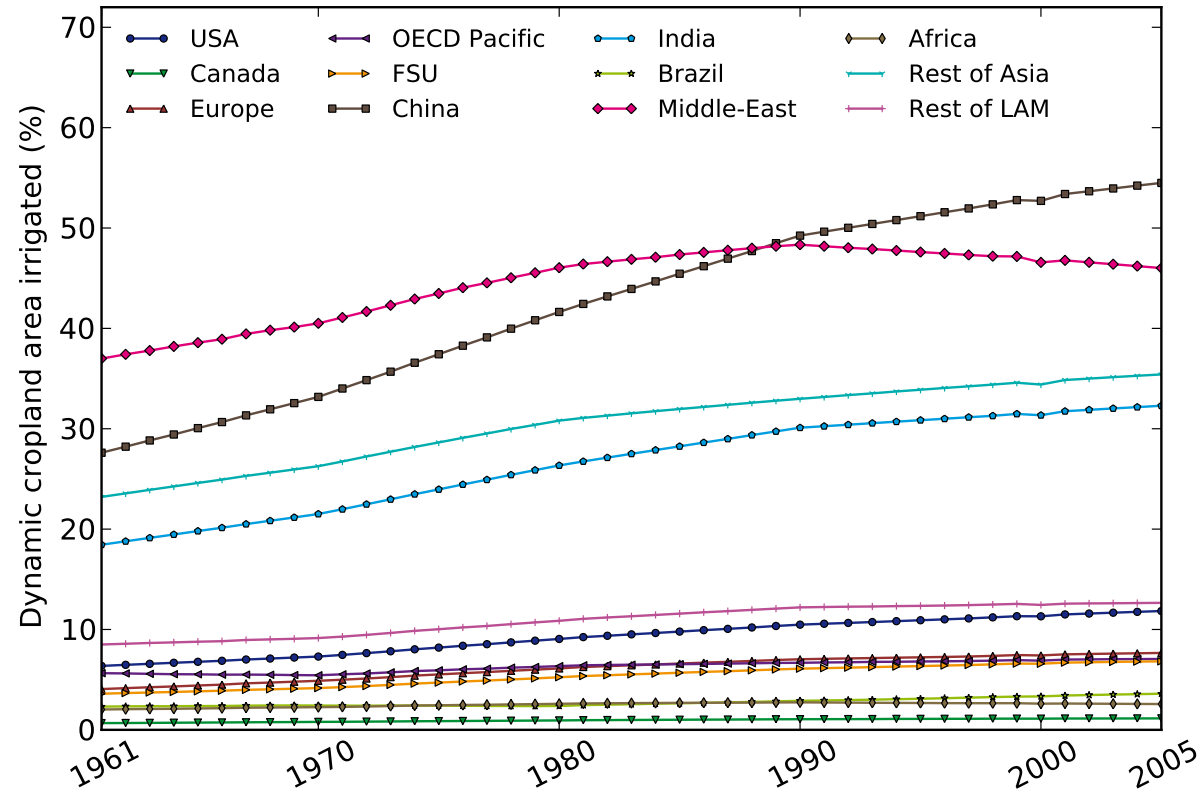

Fig. 8. Changes in total area equipped for irrigation from FAO (2012).

\section{GMDD}

6, 6975-7046, 2013

Calibration and evaluation of the

Nexus Land-Use model

F. Souty et al.

\section{Title Page}

\section{Abstract}

Introduction

Conclusions

References

Tables

Figures

14

$>1$

4

Back

Close

Full Screen / Esc

Printer-friendly Version

Interactive Discussion 


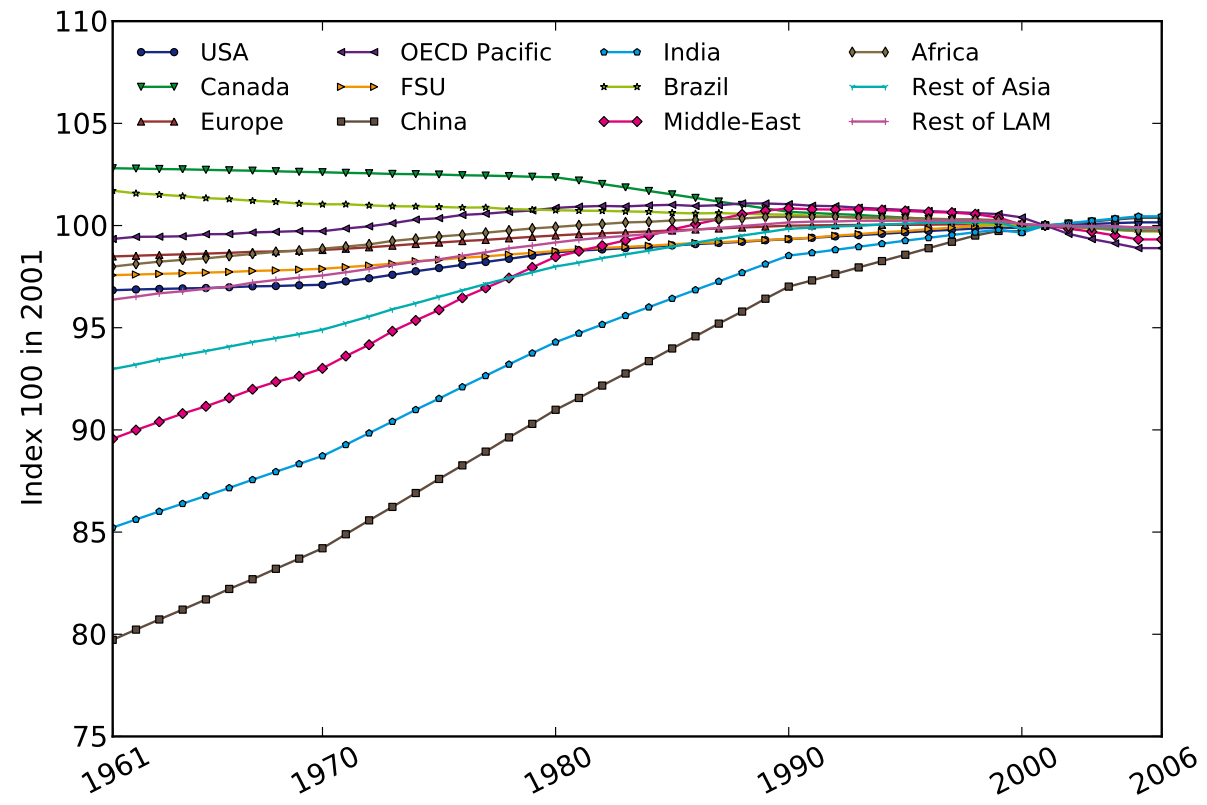

GMDD

6, 6975-7046, 2013

Calibration and evaluation of the

Nexus Land-Use model

F. Souty et al.

Title Page

Abstract

Introduction

Conclusions

References

Tables

Figures

14

$\rightarrow 1$

4

Back

Close

Full Screen / Esc

Printer-friendly Version

Interactive Discussion 

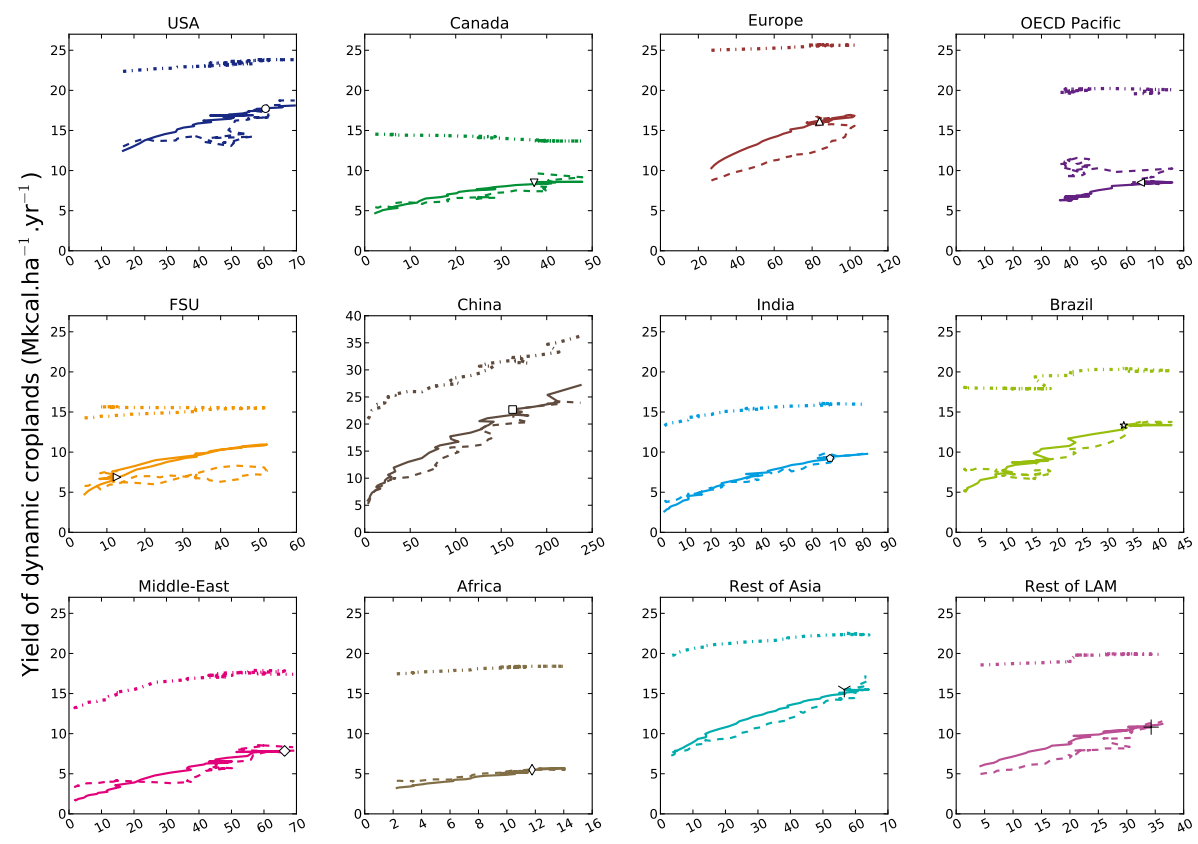

Consumption of nitrogen fertiliser per hectare $\left(\mathrm{kgN}\right.$ ha $\left.{ }^{-1}\right)$

Fig. 10. Potential, simulated and observed dynamic cropland yields as a function of nitrogen fertiliser consumption from FAO (2012) using calibrated $R_{\max }^{\min }$ ratios. If the solid line is close to the dashed one, it can be concluded that Nexus Land-Use is successful in reproducing the historical yield change of each region. Markers point out the year 2001. Note that the y-axis scale is different for China.

GMDD

$6,6975-7046,2013$

Calibration and evaluation of the

Nexus Land-Use

model

F. Souty et al.

\section{Title Page}

\section{Abstract}

Introduction

Conclusions

References

Tables

Figures

14

$\rightarrow 1$

4

Back

Close

\section{Full Screen / Esc}

Printer-friendly Version

Interactive Discussion 


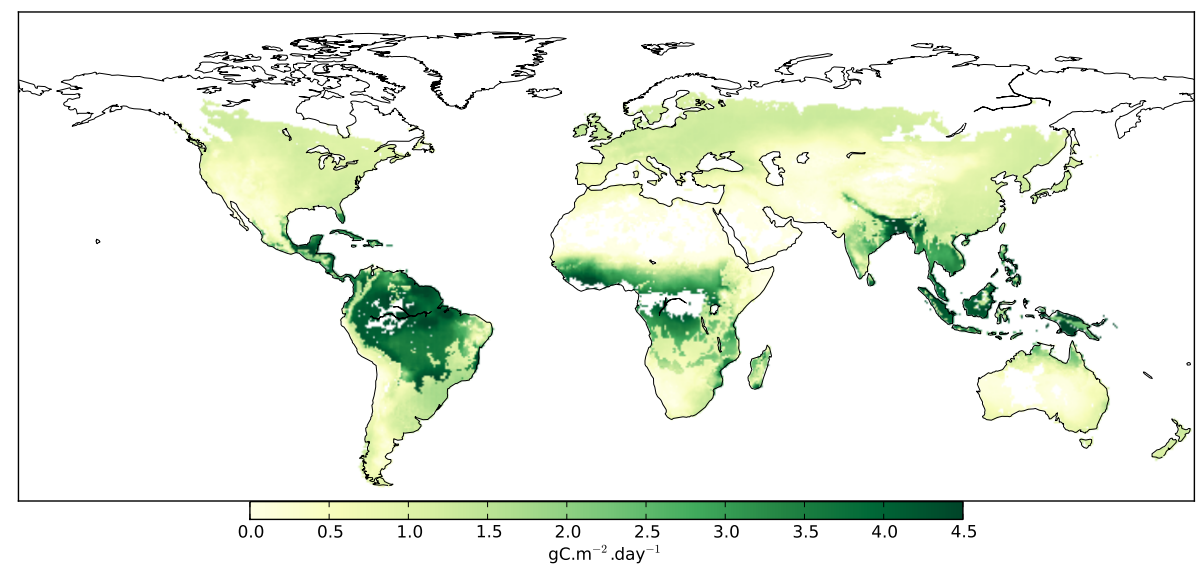

Fig. 11. Net primary productivity of grasslands (NPP, above+below ground) from the vegetation model ORCHIDEE, average over the 1995-2004 period. White pixels are those where the grassland fractional coverage in each $0.5^{\circ}$ grid point of ORCHIDEE is zero.

\section{GMDD}

$6,6975-7046,2013$

Calibration and evaluation of the

Nexus Land-Use model

F. Souty et al.

\section{Title Page}

\section{Abstract}

Introduction

Conclusions

References

Tables

Figures

14

$\rightarrow 1$

4

Back

Close

Full Screen / Esc

Printer-friendly Version

Interactive Discussion 


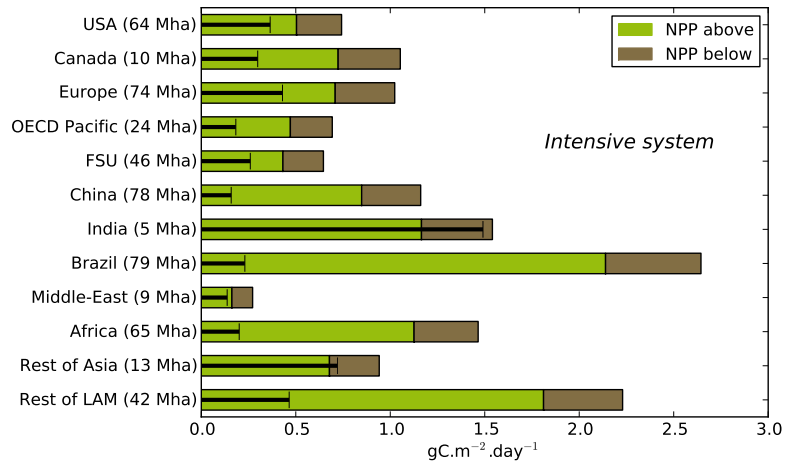

GMDD

6, 6975-7046, 2013

Calibration and

evaluation of the

Nexus Land-Use

model

F. Souty et al.

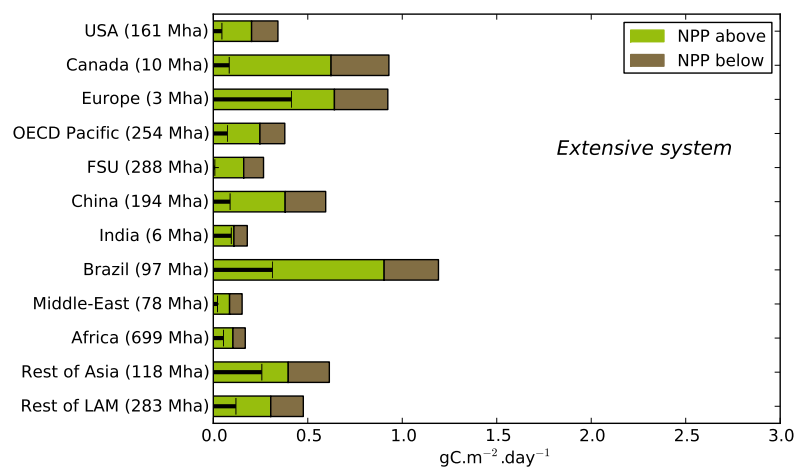

Title Page

Abstract

Introduction

Conclusions

References

Tables

Figures

14

4

Fig. 12. Mean above and below net primary productivity of grassland from the ORCHIDEE model by region. The upper figure shows mean NPP of intensive and residual pastures, the lower for extensive pastures. Black whiskers show the NPP consumed by livestock, on the intensive system and the extensive one used in Nexus Land-Use (see text). Consumed grass yields were caculated from NPP output of ORCHIDEE (in $\mathrm{m}^{-2}$ day $^{-1}$ ) by assuming that a dry ton of biomass corresponds to $4.4 \mathrm{Mkcal}$ and contains 0.5 ton of carbon, then $1 \mathrm{~g} \mathrm{Cm}^{-2}$ day $^{-1}=$ 32.2 $\mathrm{Mkcal} \mathrm{ha}^{-1} \mathrm{yr}^{-1}$.

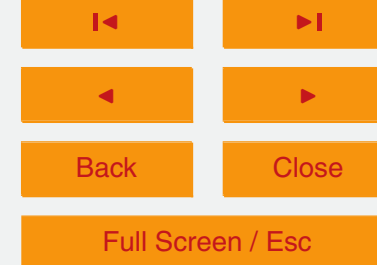

Printer-friendly Version

Interactive Discussion 

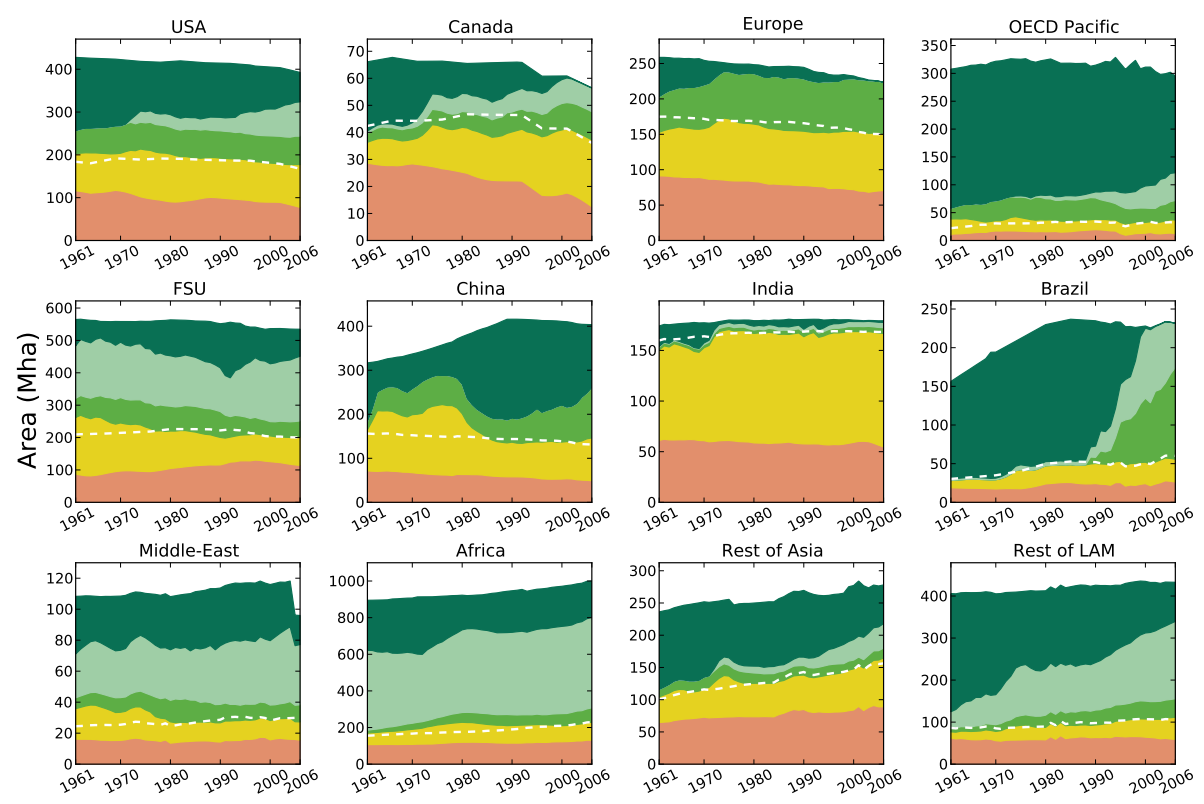

Ext. pasture

Res. pasture

Int. pastur

Dynamic cropland

Other cropland

Fig. 13. Land-use changes simulated by Nexus Land-Use over 1961-2006. The white dashed line shows cropland area reconstructed by Ramankutty and Foley (1999) used as observations.

GMDD

6, 6975-7046, 2013

Calibration and evaluation of the

Nexus Land-Use

model

F. Souty et al.

\section{Title Page}

Abstract

Introduction

Conclusions

References

Tables

Figures

14

4

Back

\section{- I}

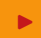

\section{Full Screen / Esc}

Printer-friendly Version

Interactive Discussion 

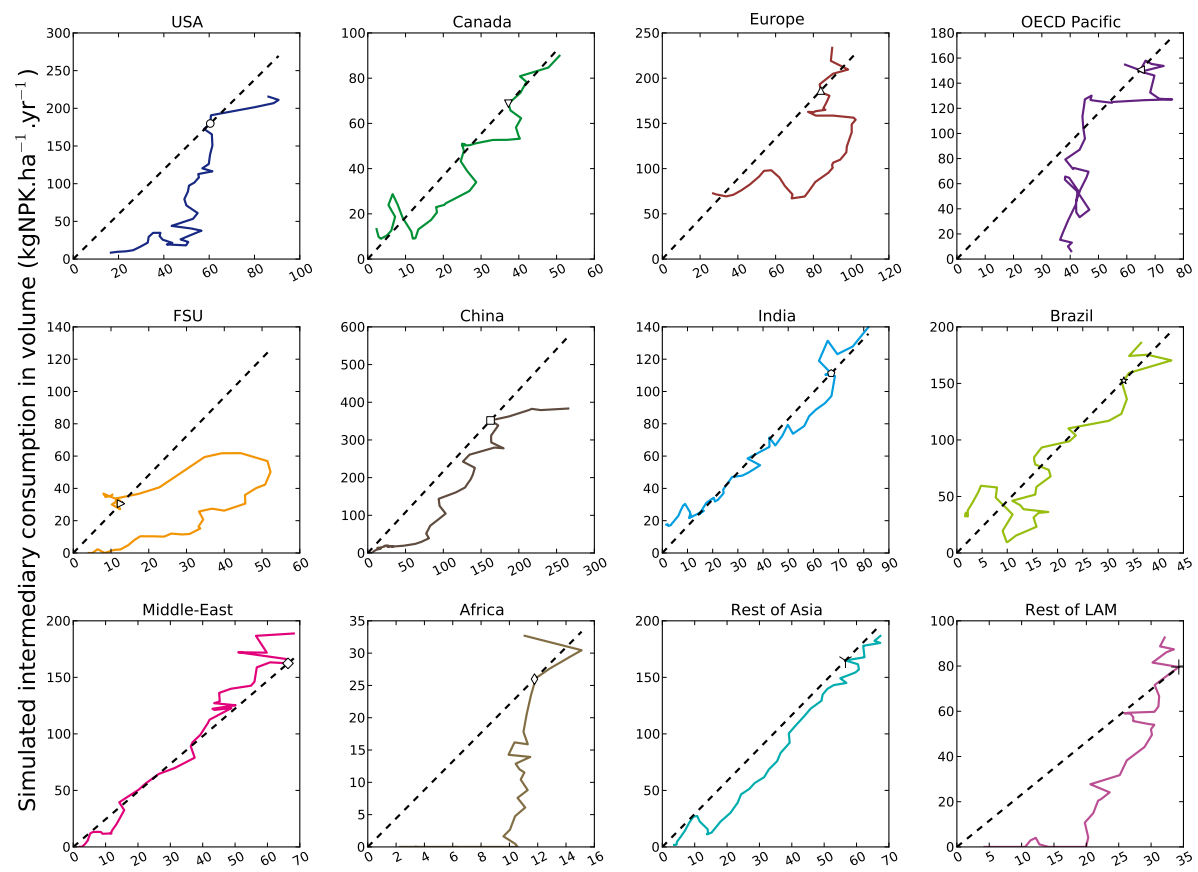

Nitrogen fertiliser consumption per hectare from FAO $\left(\mathrm{kg}_{\mathrm{N}} \mathrm{ha}^{-1}\right)$

Fig. 14. Simulated annual intermediary consumption vs. nitrogen fertiliser consumption from FAO (2012). Intermediary consumption is underestimated by the model when solid curves (simulation) are above dashed lines.

\section{GMDD}

$6,6975-7046,2013$

Calibration and evaluation of the

Nexus Land-Use model

F. Souty et al.

\section{Title Page}

Abstract

Introduction

Conclusions

References

Tables

Figures

14

$\rightarrow 1$

4

Back

Close

\section{Full Screen / Esc}

Printer-friendly Version

Interactive Discussion 

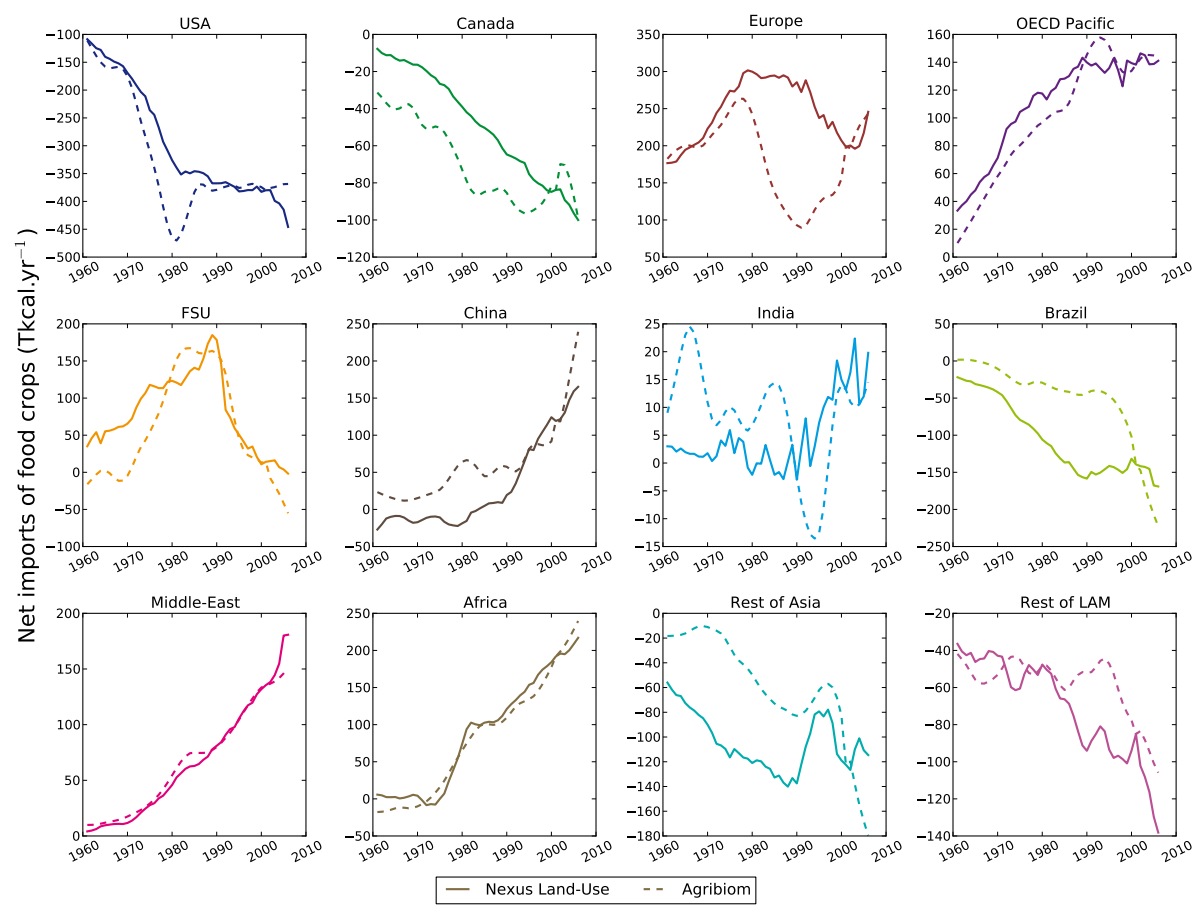

Fig. 15. Simulated net imports of food crops compared to Agribiom data.

\section{GMDD}

$6,6975-7046,2013$

Calibration and evaluation of the

Nexus Land-Use model

F. Souty et al.

\section{Title Page}

\section{Abstract}

Introduction

Conclusions

References

Tables

Figures

14

$>$ I

4

Back

Close

\section{Full Screen / Esc}

Printer-friendly Version

Interactive Discussion 


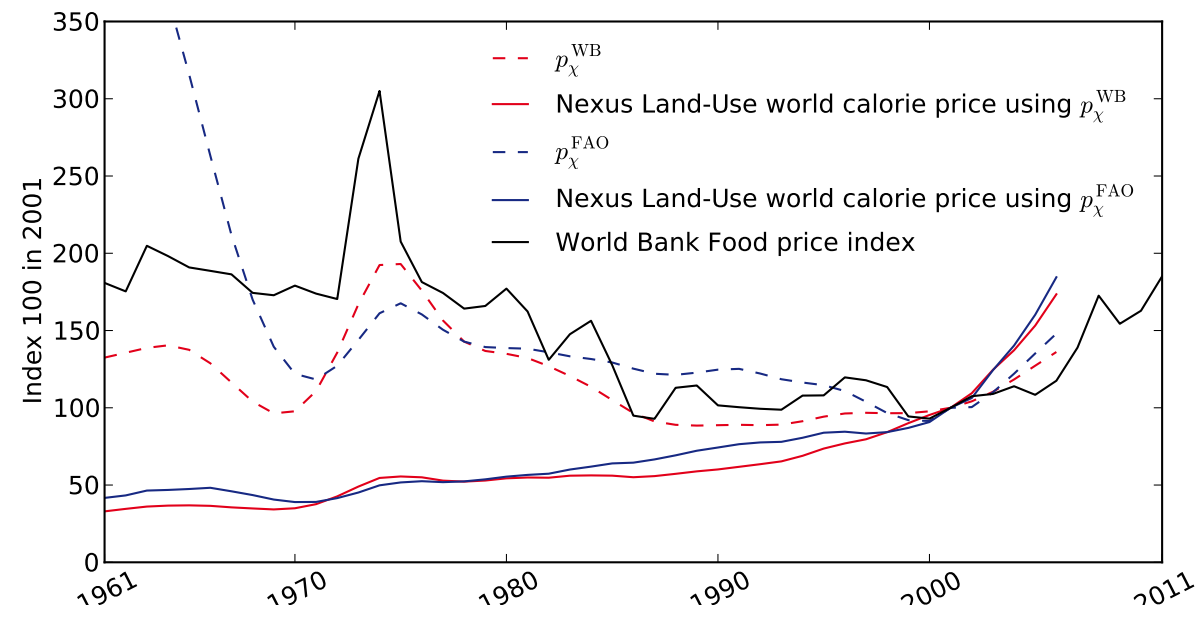

Fig. 16. Calorie price simulated by Nexus Land-Use using two different fertiliser price index values, $p_{\chi}^{\mathrm{WB}}$ from the World Bank (2012a) database (Sect. 3.2, red curves) or $p_{\chi}^{\mathrm{FAO}}$ calculated from the FAO database (blue curves). Food price index from the World Bank (2012a) (black curve).
GMDD

6, 6975-7046, 2013

Calibration and evaluation of the

Nexus Land-Use

model

F. Souty et al.

Title Page

Abstract

Introduction

Conclusions

References

Tables

Figures

14

$>1$

4

Back

Close

Full Screen / Esc

Printer-friendly Version

Interactive Discussion 


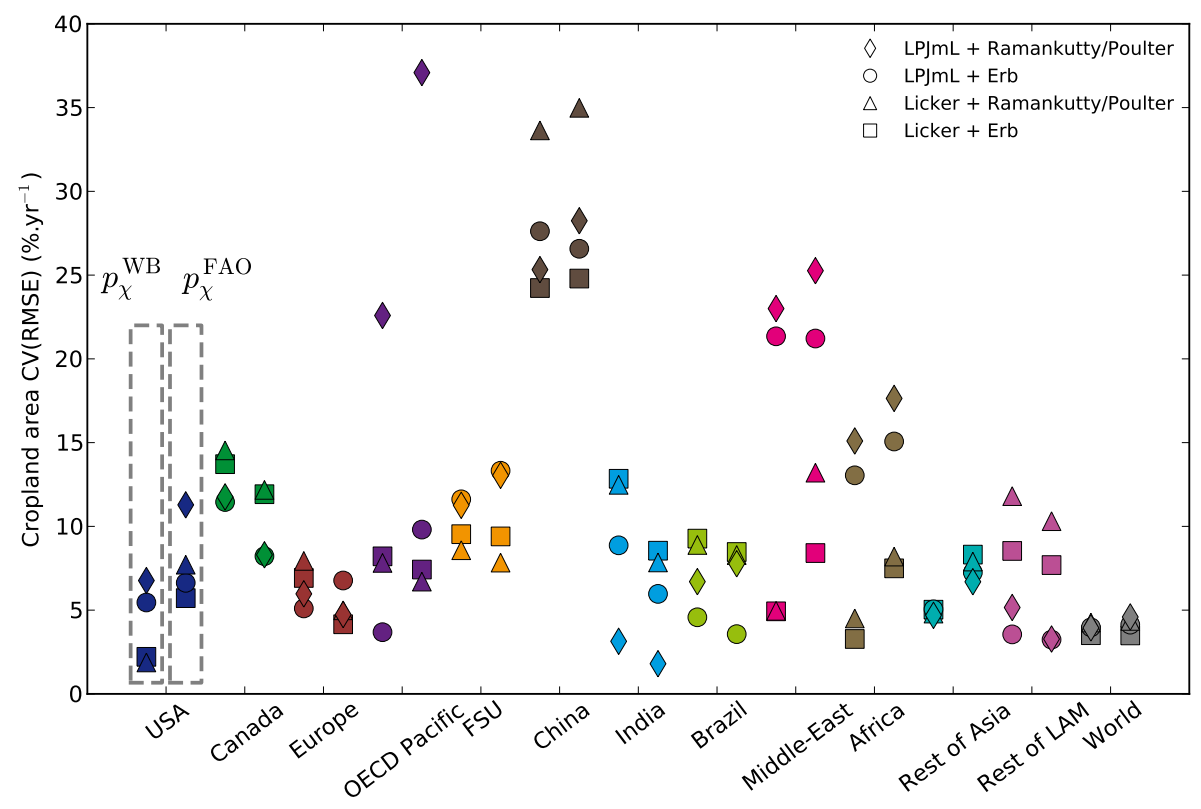

GMDD

6, 6975-7046, 2013

Calibration and evaluation of the

Nexus Land-Use

model

F. Souty et al.

\section{Title Page}

Abstract

Introduction

Conclusions

References

Tables

14

4

Back
Figures

-1

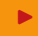

Close

Fig. 17. $C V(R M S E)_{1961-2006}^{\text {cropland }}$ depending on the yield dataset (LPJmL or Licker), the land-use dataset (Erb or Ramankutty/Poulter) and the fertiliser price index $\left(p_{\chi}^{\mathrm{FAO}}\right.$ or $\left.p_{\chi}^{\mathrm{WB}}\right)$.

\section{Full Screen / Esc}

Printer-friendly Version

Interactive Discussion 

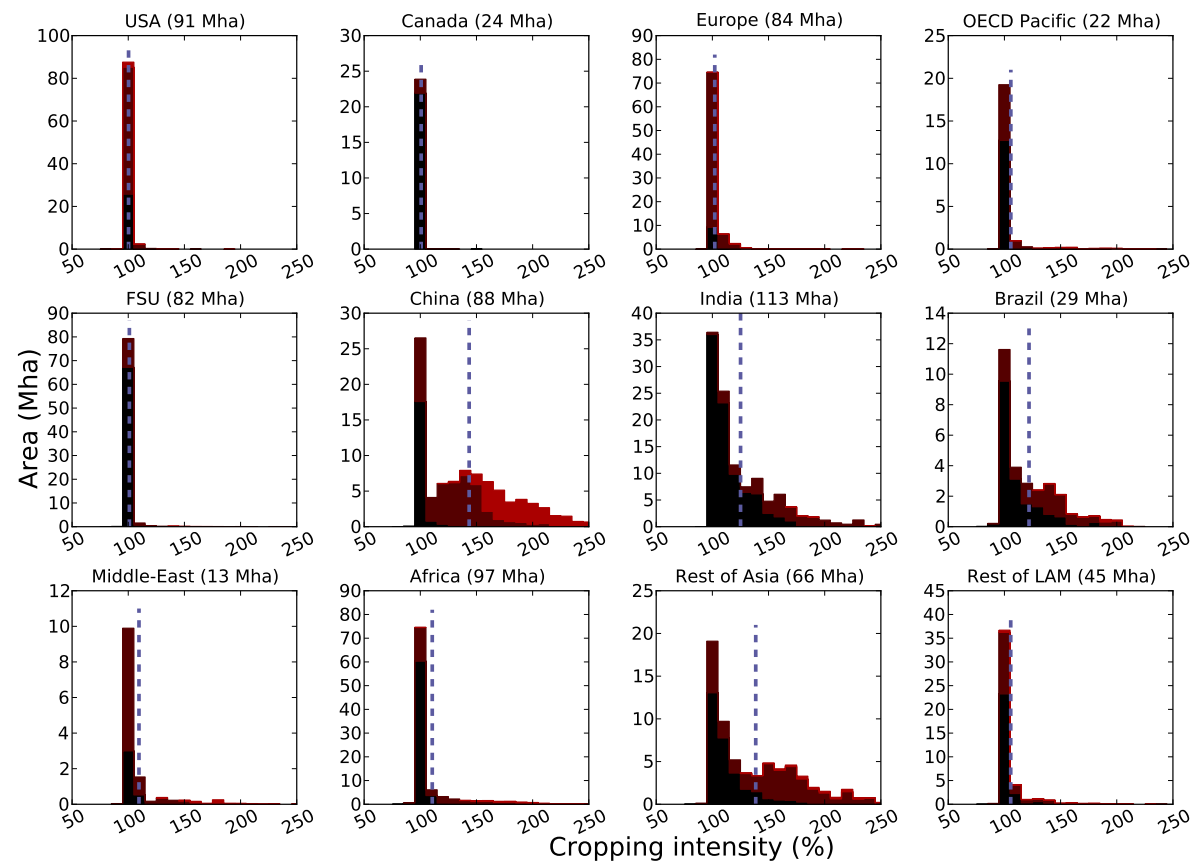

Fig. 18. Cropping Intensity $(\mathrm{Cl})$ in the 12 Nexus Land-Use regions in percent. $\mathrm{Cl}$ is defined as $\frac{f_{\mathrm{CFT}, I}^{\text {hared }}}{f_{\mathrm{CFT}, I}}$. Since data on cultivated area used $\left(f_{\mathrm{CFT}, /}\right.$ from LPJmL) do not include fallow land, areas with $\mathrm{Cl}<100 \%$ are accounted for $\mathrm{Cl}=100 \%$.
GMDD

6, 6975-7046, 2013

Calibration and evaluation of the

Nexus Land-Use

model

F. Souty et al.

Title Page

Abstract

Introduction

Conclusions

References

Tables

Figures

14

$>$ I

4

Back

Close

Full Screen / Esc

Printer-friendly Version

Interactive Discussion 


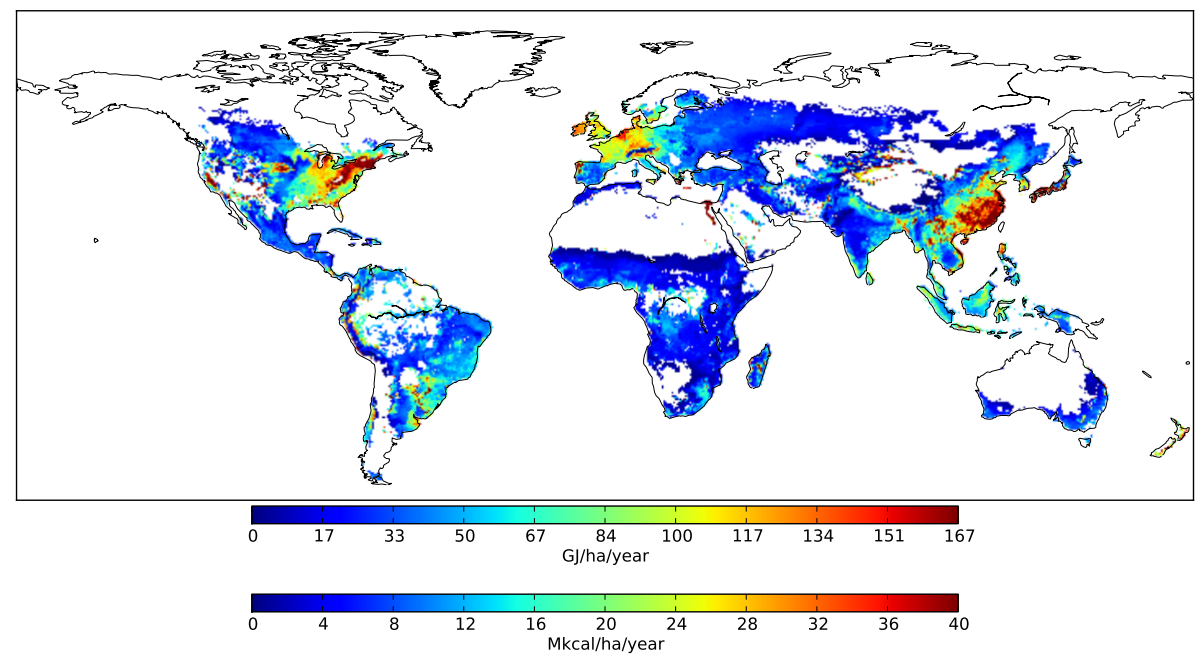

Fig. 19. Representative actual yield using the LPJmL dataset.

\section{GMDD}

6, 6975-7046, 2013

Calibration and evaluation of the

Nexus Land-Use model

F. Souty et al.

Title Page

Abstract

Introduction

Conclusions

References

Tables

Figures

14

$\rightarrow 1$

4

Back

Close

Full Screen / Esc

Printer-friendly Version

Interactive Discussion 


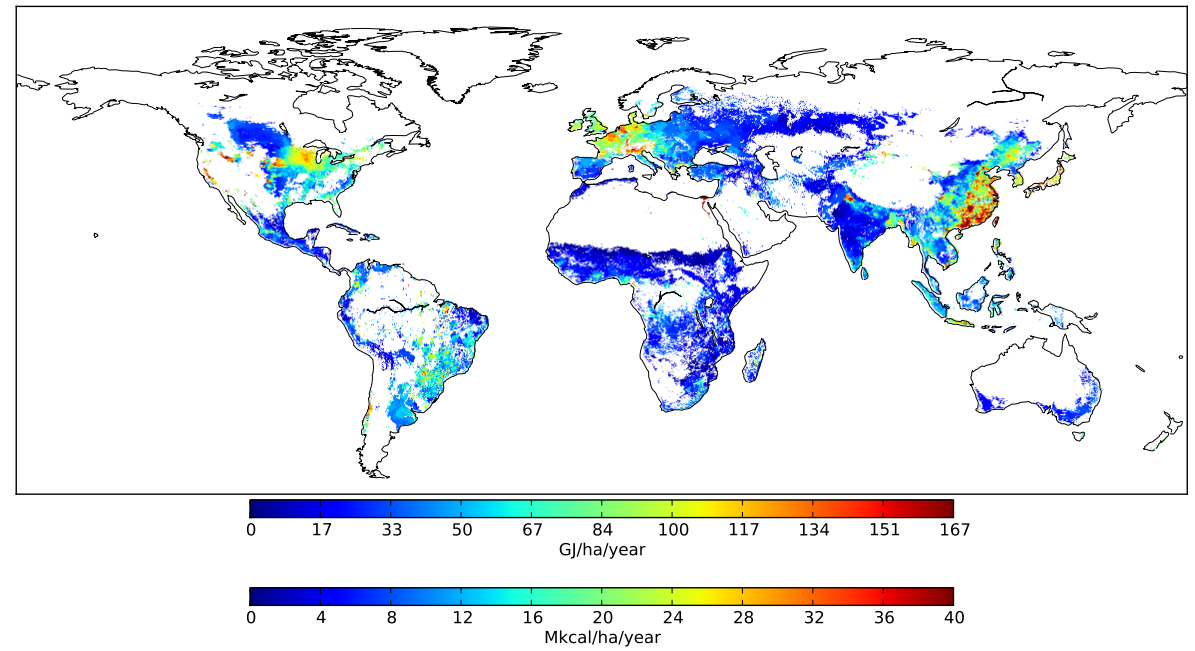

Fig. 20. Representative actual yield using the Licker et al. (2010) dataset.

Calibration and evaluation of the

Nexus Land-Use model

F. Souty et al.

Title Page

Abstract Introduction

Conclusions References

Tables Figures

14 I 4

Back

Close

Full Screen / Esc

Printer-friendly Version

Interactive Discussion 


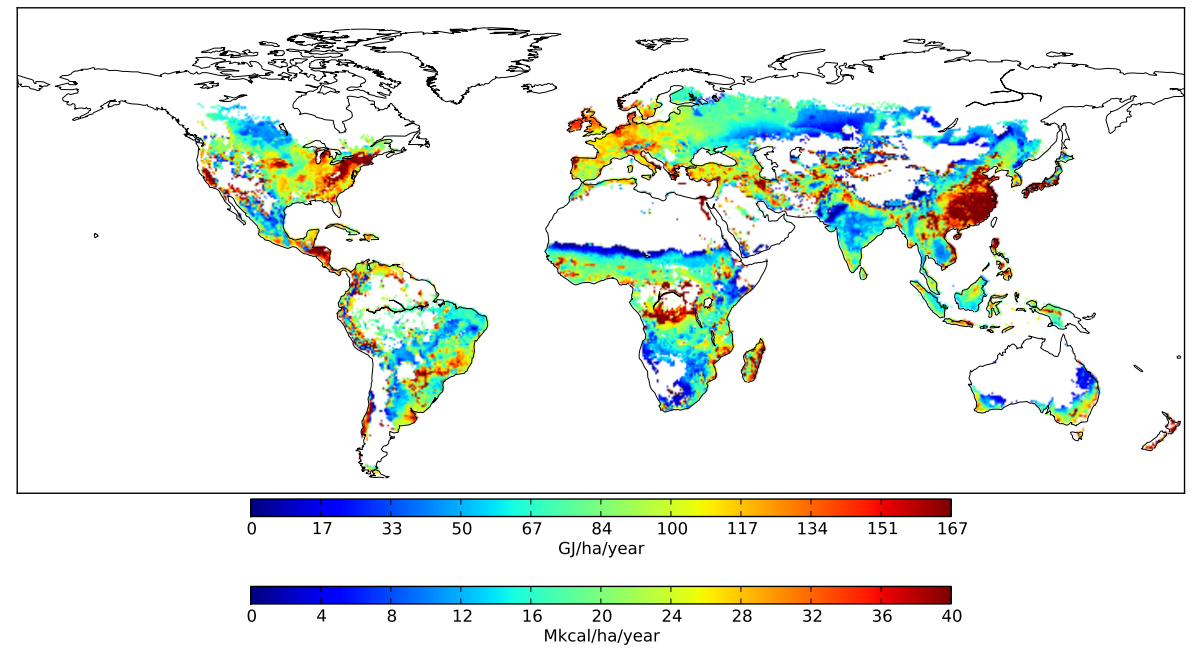

\section{GMDD}

6, 6975-7046, 2013

Calibration and evaluation of the

Nexus Land-Use model

F. Souty et al.

Title Page

Abstract

Introduction

Conclusions

References

Tables

Figures

14

$>$ I

4

Back

Close

Full Screen / Esc

Printer-friendly Version

Interactive Discussion 


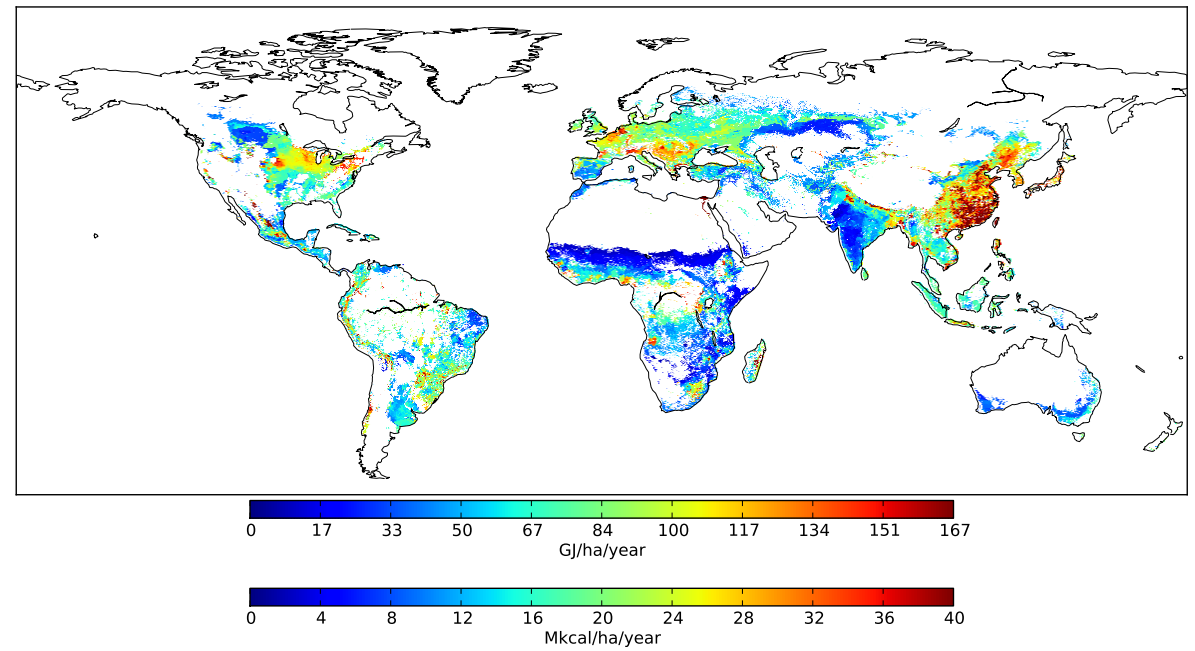

\section{GMDD}

6, 6975-7046, 2013

Calibration and evaluation of the

Nexus Land-Use model

F. Souty et al.

Title Page

Abstract

Introduction

Conclusions

References

Tables

Figures

14

$>$ I

4

Back

Close

Full Screen / Esc

Printer-friendly Version

Interactive Discussion 

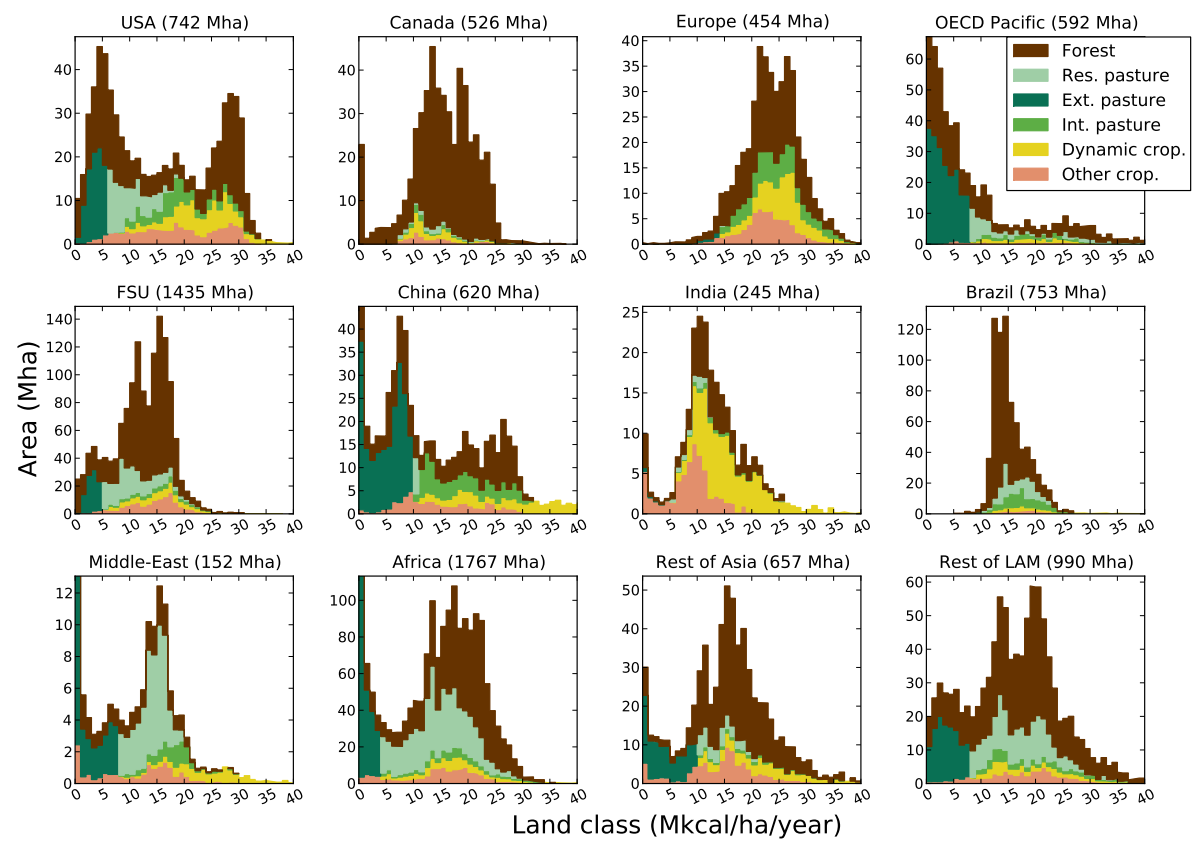

Fig. 23. Histograms of the land area classes of potential yield in the 12 Nexus Land-Use regions at the base year 2001 using the LPJmL yield dataset, land-use maps of cropland and pasture from Ramankutty et al. (2008) and a map of forest from Poulter et al. (2011). The x-axis in $\mathrm{GJ} \mathrm{ha}^{-1} \mathrm{yr}^{-1}$ ranges from 0 to 167 .
GMDD

6, 6975-7046, 2013

Calibration and evaluation of the

Nexus Land-Use

model

F. Souty et al.

\section{Title Page}

Conclusions

References
Tables

14

4

Back

\section{Figures}

$\rightarrow 1$

Close

\section{Full Screen / Esc}

Printer-friendly Version

Interactive Discussion 

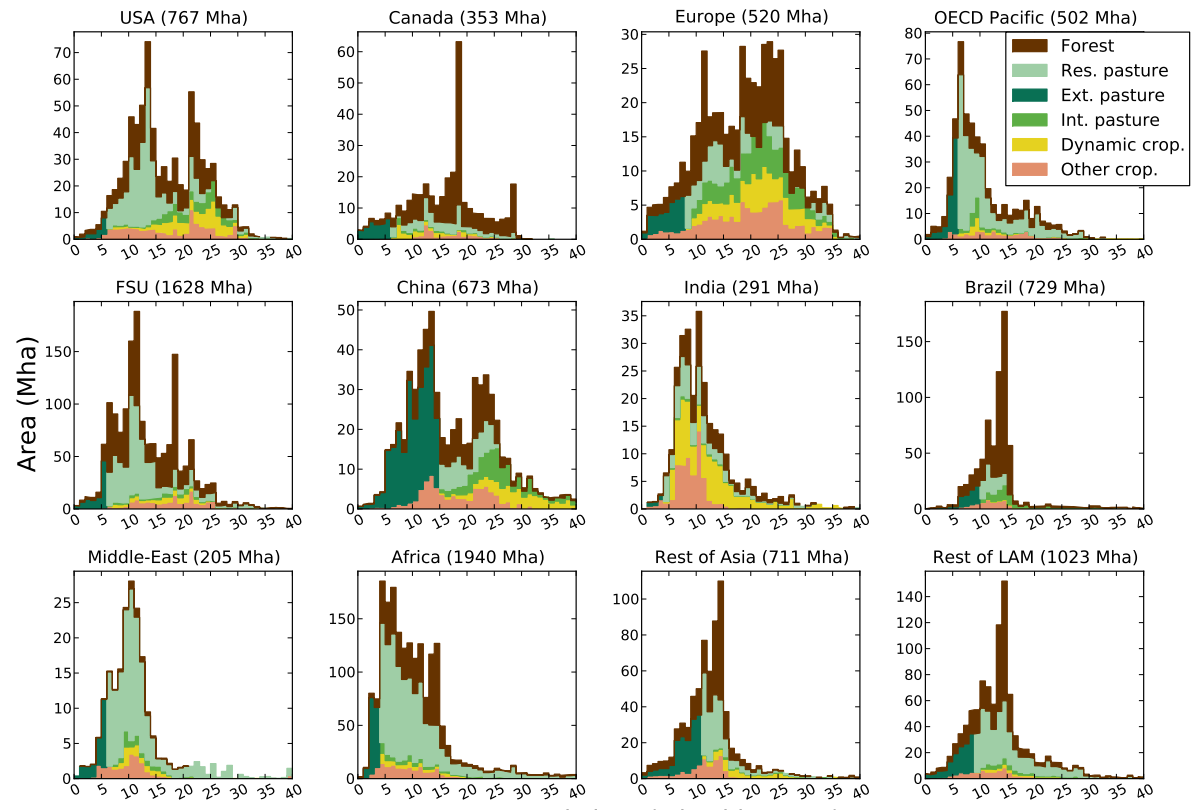

Fig. 24. Histograms of the land area classes of potential yield in the 12 Nexus Land-Use regions at the base year 2001 using the Licker et al. (2010) yield dataset and the Erb et al. (2007) landuse dataset. The x-axis in $\mathrm{GJha}^{-1} \mathrm{yr}^{-1}$ ranges from 0 to 167 .
GMDD

6, 6975-7046, 2013

Calibration and evaluation of the

Nexus Land-Use

model

F. Souty et al.

\section{Title Page}

Abstract Introduction

Conclusions References
Tables

14

4

Back

\section{Figures}

$\rightarrow 1$

Close

\section{Full Screen / Esc}

Printer-friendly Version

Interactive Discussion 


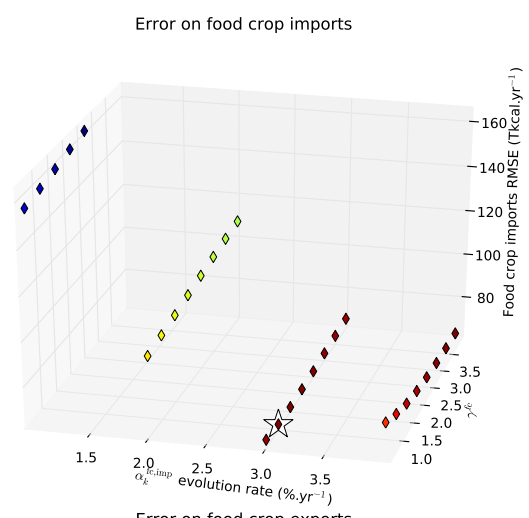

Error on food crop exports

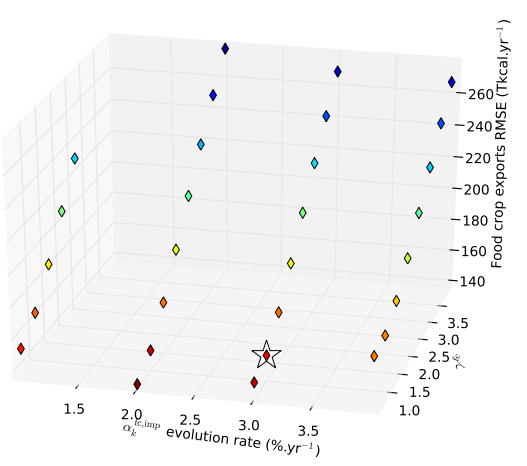

Error on ruminant product imports

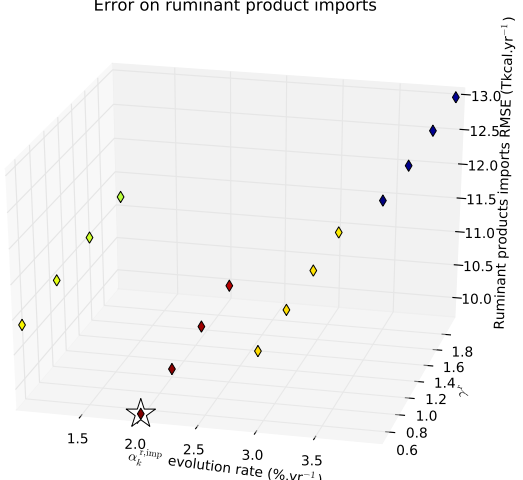

Error on ruminant product exports

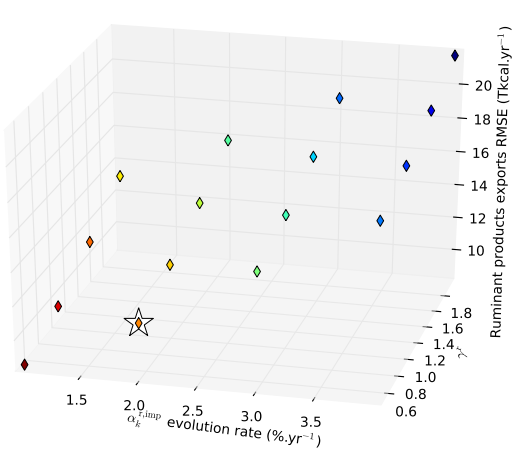

Fig. 25. Global root-mean-square error on imports and exports of food crops and ruminant products. The white stars point out calibrated values.

\section{GMDD}

$6,6975-7046,2013$

Calibration and evaluation of the

Nexus Land-Use model

F. Souty et al.

\section{Title Page}

\section{Abstract}

Introduction

Conclusions

References

Tables

Figures

14

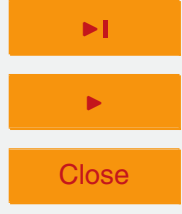

Back

Full Screen / Esc

Printer-friendly Version 

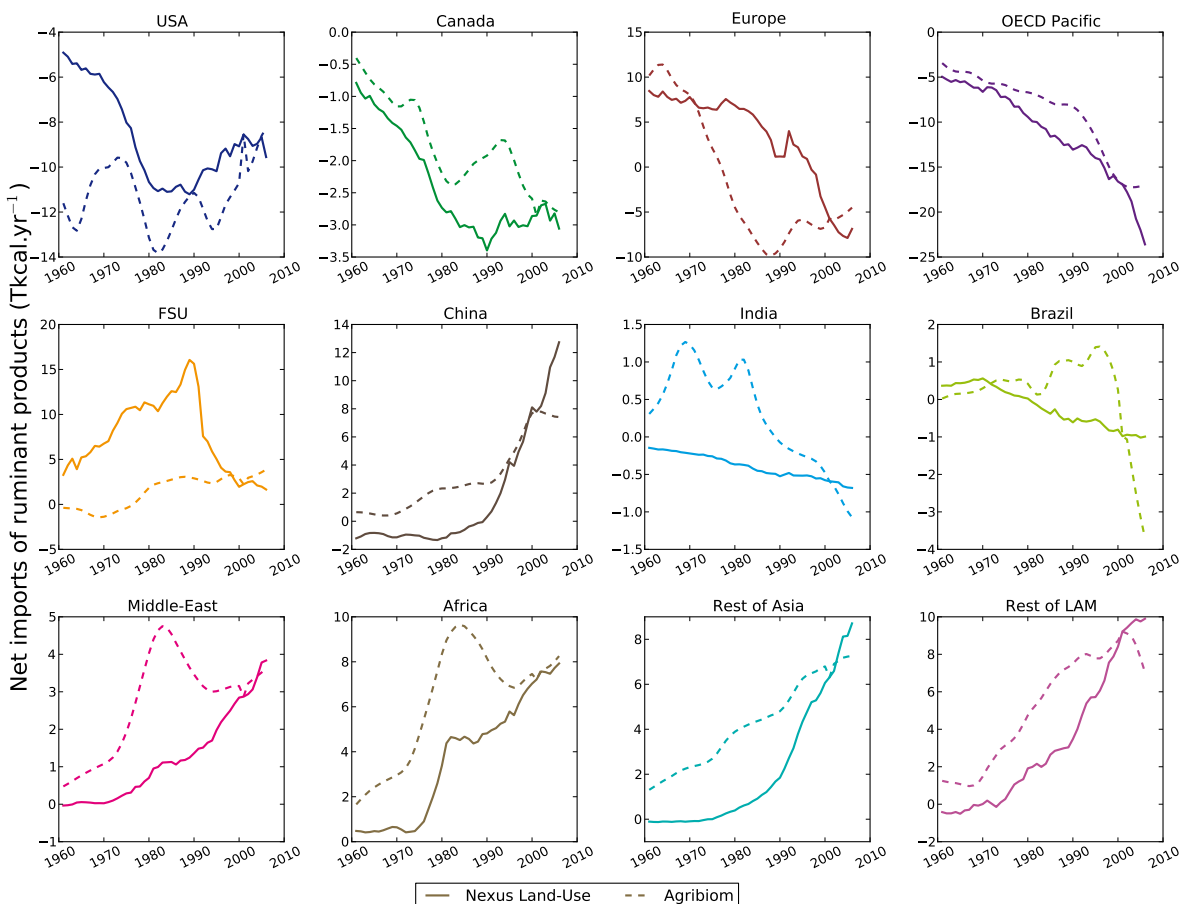

Fig. 26. Net imports of ruminant products compared to Agribiom data.

\section{GMDD}

$6,6975-7046,2013$

Calibration and evaluation of the

Nexus Land-Use model

F. Souty et al.

\section{Title Page}

Abstract

Introduction

Conclusions

References

Tables

Figures

14

$\rightarrow 1$

4

Back

Close

\section{Full Screen / Esc}

Printer-friendly Version

Interactive Discussion 

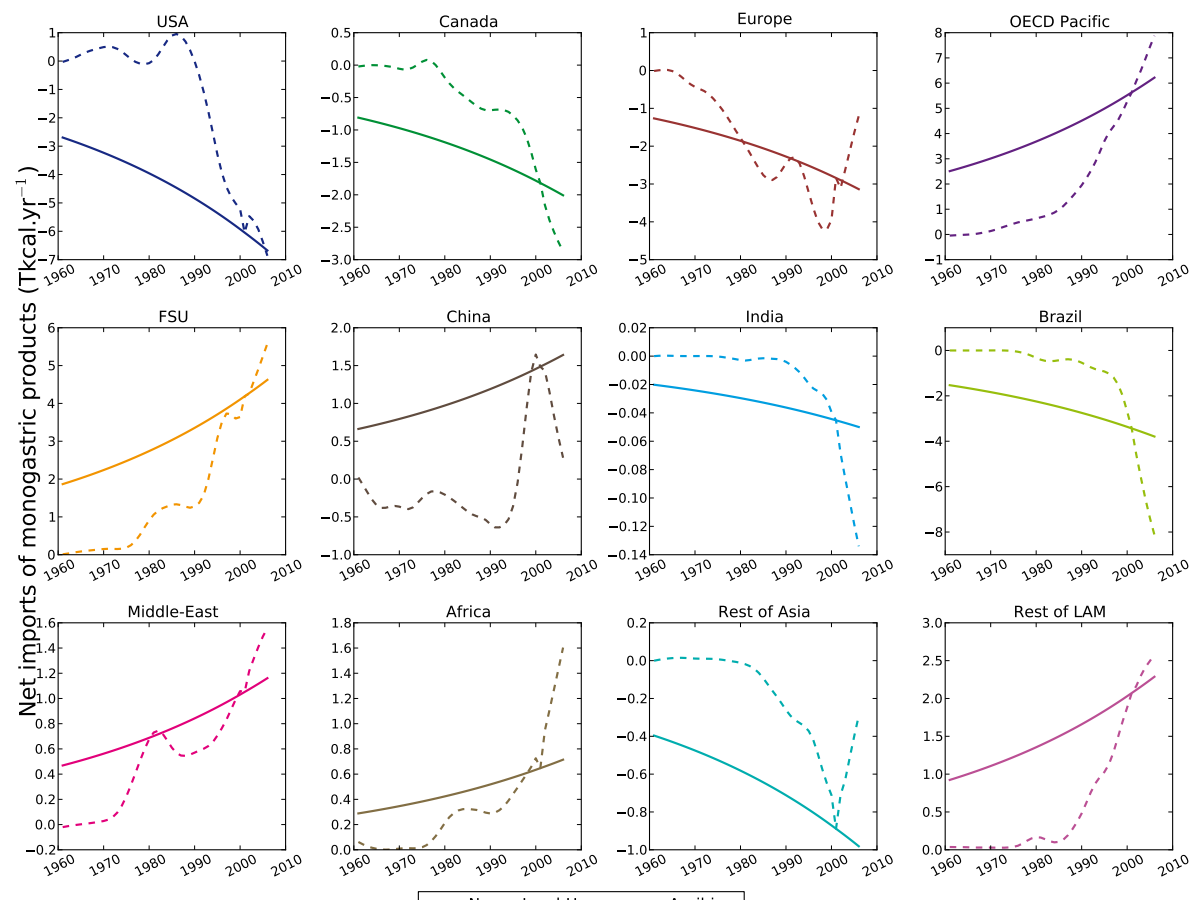

- Nexus Land-Use $\quad$ - - Agribiom
GMDD

6, 6975-7046, 2013

Calibration and evaluation of the

Nexus Land-Use model

F. Souty et al.

\section{Title Page}

Abstract

Introduction

Conclusions

References

Tables

Figures

14

$\rightarrow 1$

4

Back

Close

Full Screen / Esc

Printer-friendly Version

Interactive Discussion 